DOE/NV-325-Rev. 8

September 2010

\title{
Nevada National Security Site Waste Acceptance Criteria
}

\author{
Prepared by \\ U.S. Department of Energy \\ National Nuclear Security Administration \\ Nevada Site Office \\ Waste Management Project
}

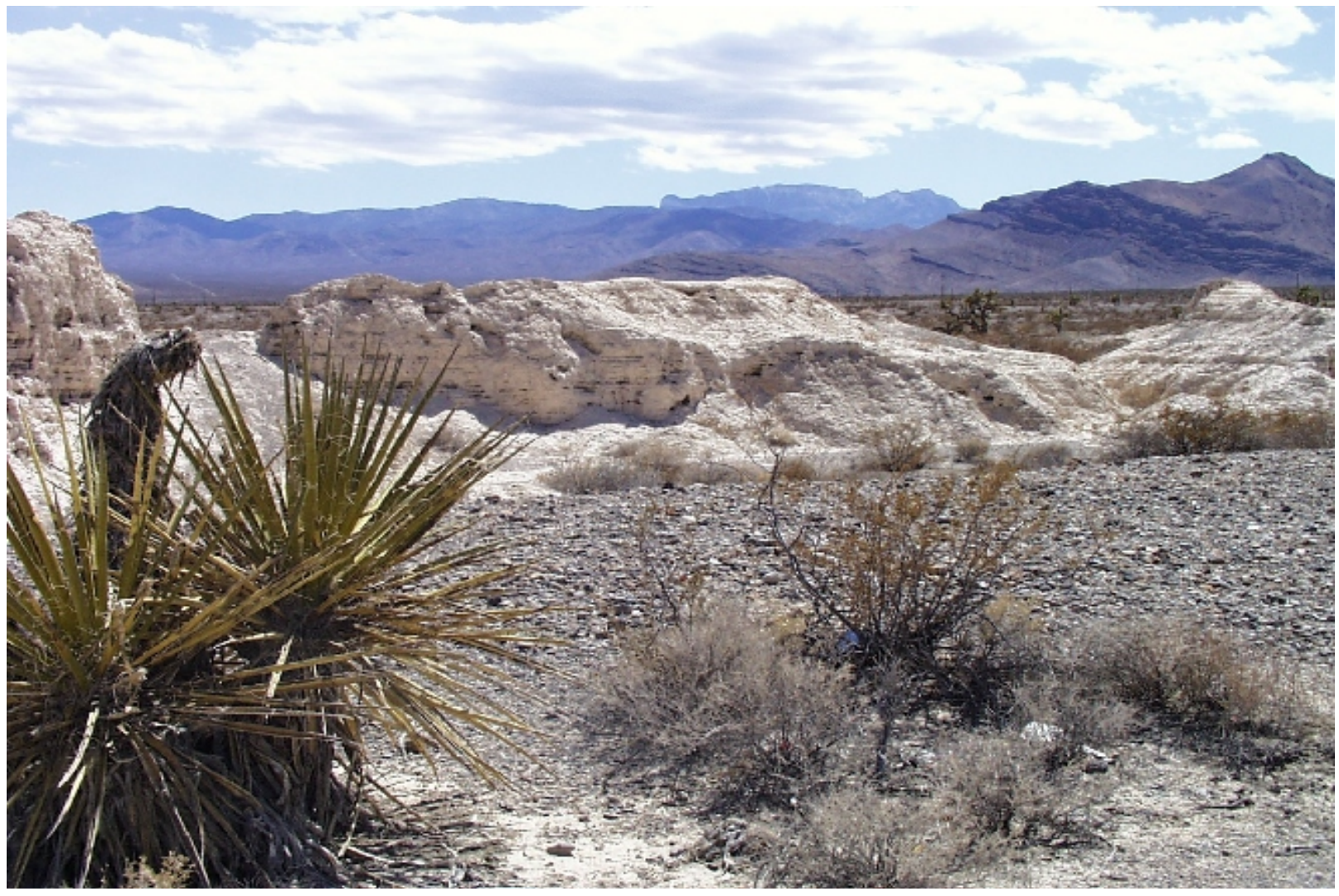




\section{Disclaimer Notice}

Reference herein to any specific commercial product, process, or service by trade name, trade mark, manufacturer, or otherwise does not necessarily constitute or imply its endorsement, recommendation, or favoring by the United States Government or any agency thereof.

Available for sale to the public, in paper, from:

U.S. Department of Commerce

National Technical Information Service

5301 Shawnee Road

Alexandria, VA 22312

Phone: (800) 553-6847

Fax: (703) 605-6900

E-mail: orders@ntis.gov

Online Ordering: http://www.ntis.gov/help/ordermethods.aspx

Available electronically at http://www.osti.gov/bridge

Available for a processing fee to the U.S. Department of Energy and its contractors, in paper, from:

U.S. Department of Energy

Office of Scientific and Technical Information

P.O. Box 62

Oak Ridge, TN 37831-0062

Phone: (865) 576-8401

Fax: (865) 576-5728

E-mail: reports@adonis.osti.gov

Photograph on front cover: Desert National Wildlife Range landscape located southeast of Mercury, Nevada 


\title{
Nevada National Security Site Waste Acceptance Criteria
}

Issued September 2010

Effective September 2010

\author{
Prepared by \\ U.S. Department of Energy \\ National Nuclear Security Administration \\ Nevada Site Office \\ Waste Management Project
}


This page intentionally left blank. 
Nevada National Security Site Waste Acceptance Criteria

Approval Signatures

This document is correct and the process and criteria stated within meet the U.S. Department of Energy and appropriate federal regulation requirements.

Approved and Issued by:

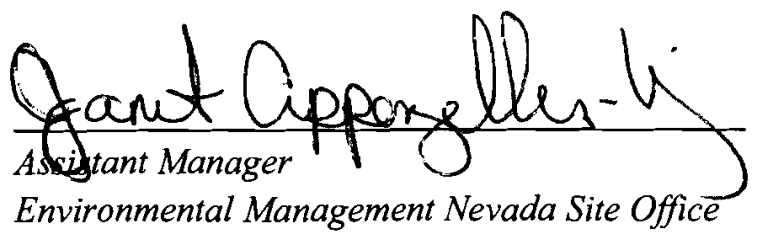

National Nuclear Security Administration

U.S. Department of Energy

Concur:

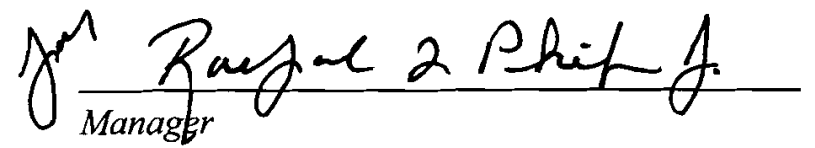

Nevada Site Office

National Nuclear Security Administration

U.S. Department of Energy

Concur:

Concur:

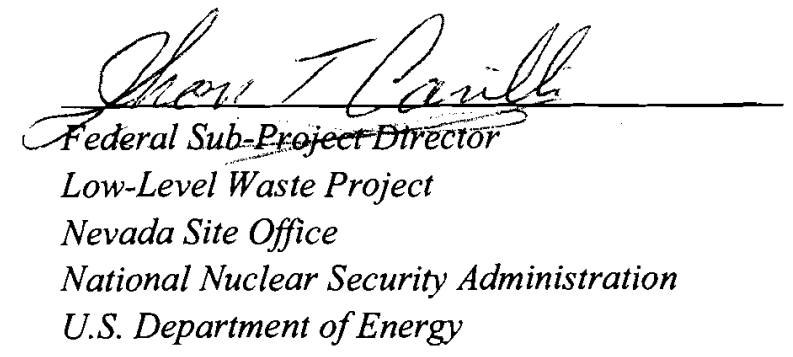

Date: $9 / 2 / 10$

Date:

9.3 .10

Date: $9 / 2 / 2010$

Date: $9 / 2 / 20 / 0$

September 2010

i 
NNSSWAC Revision History

\begin{tabular}{|c|c|c|}
\hline Date & Pages Changed & Revision \\
\hline 1981 & & * Historical note below. \\
\hline 09/1996 & All & Rev. 0 \\
\hline 08/1997 & All & Rev. 1 \\
\hline $05 / 1999$ & All & Rev. 2 \\
\hline $02 / 2000$ & i, vi, 3-5, Ref-1 & Rev. 2, DCN DOE/NV-325-03-01 \\
\hline $11 / 2000$ & All & Rev. 3 \\
\hline $01 / 2002$ & All & Rev. 4 \\
\hline $10 / 2003$ & All & Rev. 5 \\
\hline $07 / 2005$ & 3-8, 3-10, Appendix G & Rev. 5-01, DOE/NV-325-Rev 5-DCN-05-01 \\
\hline $10 / 2005$ & All & Rev. 6 \\
\hline $06 / 2006$ & $\begin{array}{l}\text { ii, 3-1, 3-6, 3-9,3-13, 4-2, 4-5, 6-3, 6-4, } \\
\text { B-1, E-1, E-3, G-1, H-2, } \\
\text { Ref-4 }\end{array}$ & Rev. 6-01, DOE/NV-325-Rev 6-DCN-06-01 \\
\hline $10 / 2006$ & $\begin{array}{l}\text { i, ii- viii, 1-1, 1-2, 1-3, 2-1, 2-3, 3-1, 3- } \\
4,3-6,3-7,3-8,3-9,3-11,3-12,3-16, \\
\text { 6-1, 6-2, 6-3, 6-4, 6-5, 6-6, 6-7, B-1, C- } \\
\text { 1, C-2, C-4, D-1, D-2, D-4, E-2, E-9, G- } \\
\text { 3, H-1, Ref-3, Ref-4 }\end{array}$ & Rev. 6-02, DOE/NV-325-Rev 6-DCN-06-02 \\
\hline $06 / 2008$ & All & $\begin{array}{l}\text { Rev. } 7 \text { - Clarifications and edits based on } \\
\text { NNSA/NSO, NDEP, RWAP, and Waste Generator } \\
\text { reviews. Revisions identified by change bars. }\end{array}$ \\
\hline $05 / 2009$ & $\begin{array}{l}\text { Incorporate new classified waste } \\
\text { disposal requirement; remove the term } \\
\text { "storage" for waste received at NNSS. }\end{array}$ & $\begin{array}{l}\text { Rev. 7-01, Sections, 1.1, 3.1.18, 3.2.8, 3.2.10 } \\
\text { App. D, App. H, and References }\end{array}$ \\
\hline $09 / 2010$ & $\begin{array}{l}\text { Selected areas as stated, Incorporate } \\
\text { new Appendix B }\end{array}$ & $\begin{array}{l}\text { Rev. 8, Change NTS to NNSS, 3.1.15, 3.1.18, } \\
\text { 3.1.19, 3.2.5, 3.2.13, 3.2.14, 3.3.1, 3.3.5.2, 3.3.6.1, } \\
\text { 6.3.1, 6.3.4, Appendix B, C, E, F, H }\end{array}$ \\
\hline
\end{tabular}

* Historical Note: The original Nevada Test Site Waste Acceptance Criteria known then as "NVO-185" was written in 1981 and underwent five or six revisions. It came into being when the NTS first started receiving significant quantities of offsite $L L W$. While the original NVO-185 was far less prescriptive and rigorous than the current version, many of the current DOE Order requirements, laws, and regulation did not exist. In 1996, NVO185 was replaced by the current DOE/NV-325 and was titled as the "Nevada Test Site Waste Acceptance Criteria (NTSWAC)." What we know today as the NNSSWAC was an evolution of requirements spanning almost three decades of waste acceptance at the NNSS. 


\section{Table of Contents}

1.0 Radioactive Waste Management at the Nevada National Security Site .................. 1-1

$1.1 \quad$ Purpose and Scope ...............................................................................1-1

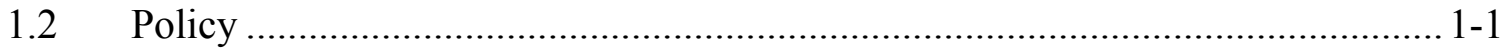

1.2.1 NNSA/NSO Policies ................................................................... $1-1$

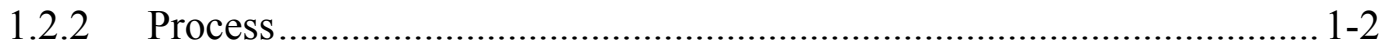

1.2.3 Waste Type and Eligibility Determination............................................. 1-2

1.2.4 Regulators and Stakeholders …………………............................... 1-2

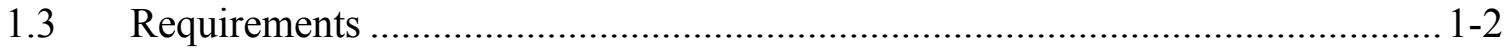

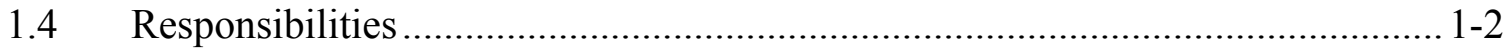

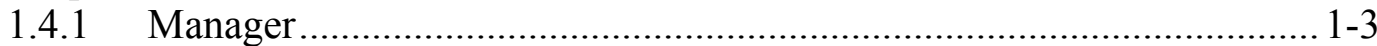

1.4.2 Assistant Manager for Environmental Management (AMEM) ............... 1-3

1.4.3 Federal Project Director, Waste Management Project ............................. 1-3

1.4.4 Federal Sub-Project Director, Low-Level Waste Project.......................... 1-3

1.4.5 Radioactive Waste Acceptance Program Task Manager.......................... 1-3

1.4.6 RWAP Manager ........................................................................... 1-3

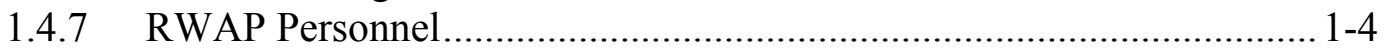

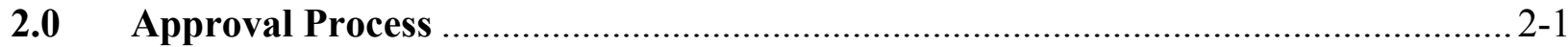

$2.1 \quad$ Generator Document Requirements............................................................ 2-1

2.1.1 Quality Assurance Program Plan ........................................................2-1

2.1.2 NNSSWAC Implementation Crosswalk ...............................................2-1

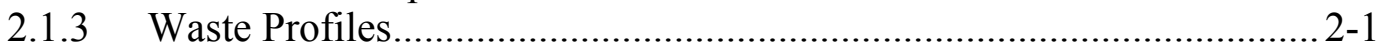

2.1.4 Certification Personnel List.............................................................. 2-2

2.1.5 Document and Personnel Changes .................................................... 2-2

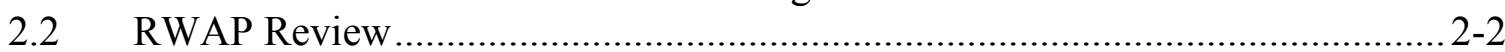

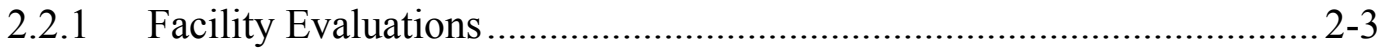

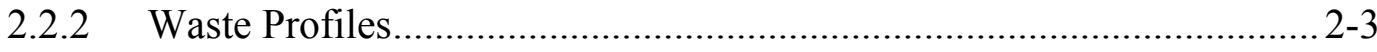

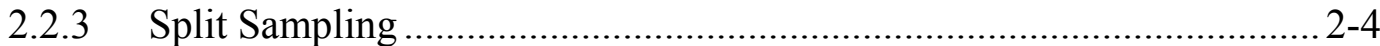

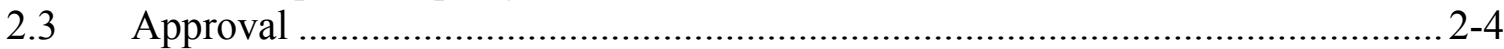

2.4. Suspending Approval.................................................................................... 2-5

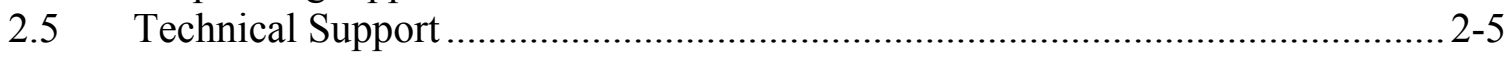

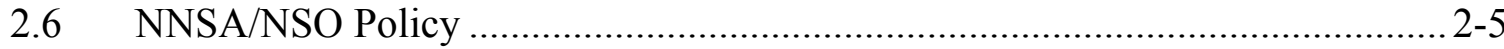

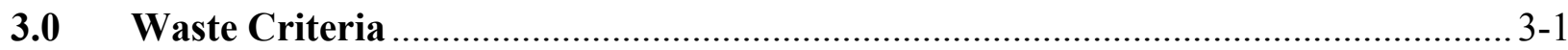

3.1 General Waste Form Criteria …………................................................... 3-1

3.1.1 Transuranics ................................................................................... 3-1

3.1.2 Radionuclide Content or Concentration ................................................ 3-1

3.1.3 Reserved to maintain section numbering. ............................................... 3-1

3.1.4 Hazardous Waste ................................................................................ 3-1

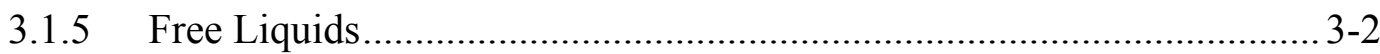

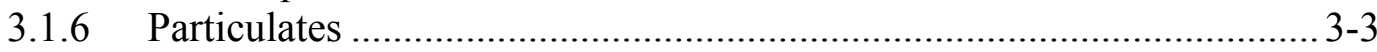

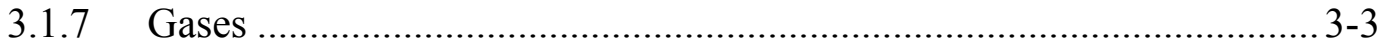

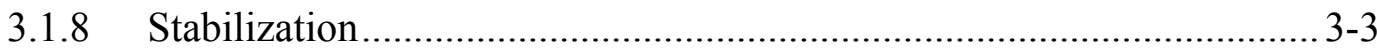




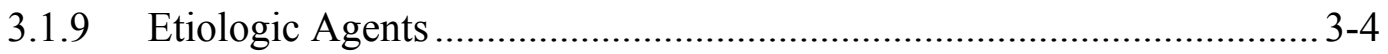

3.1.10 Chelating Agents ……..................................................................

3.1.11 Polychlorinated Biphenyls ............................................................. 3-4

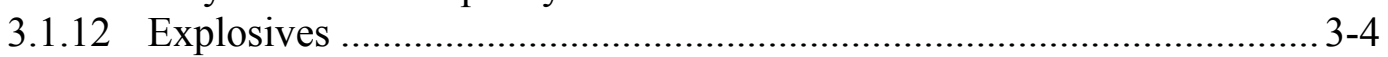

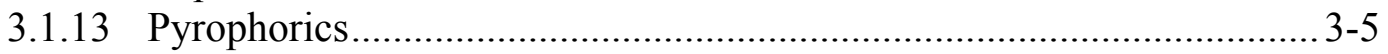

3.1.14 Sealed Sources.............................................................................. 3-5

3.1.15 Low-Level Waste Containing Regulated Asbestos.................................. 3-5

3.1.16 Radioactive Animal Carcasses ............................................................3-6

3.1.17 Beryllium Waste .............................................................................. 3-7

3.1.18 Classified Waste ................................................................................... 3-7

3.1.19 Petroleum Hydrocarbon Burdened LLW ............................................... 3-7

$3.2 \quad$ Waste Package Criteria ……………………....................................... 3-8

3.2.1 Nuclear Criticality Safety .............................................................. 3-8

3.2.2 Package Activity Limitations ............................................................ 3-8

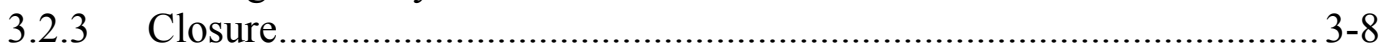

3.2.4 Lead Shielding ...................................................................... 3-8

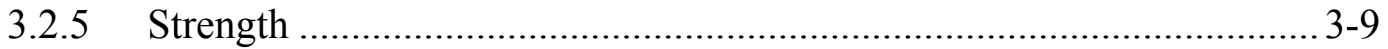

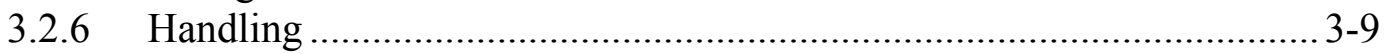

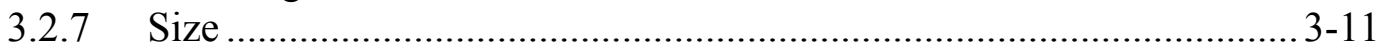

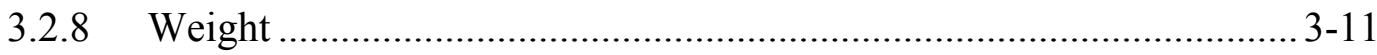

3.2.9 Loading (Void Space) ................................................................ 3-11

3.2.10 Package Protection ...................................................................... 3-12

3.2.11 Marking and Labeling .................................................................... 3-12

3.2.12 Bar Coding ………….......................................................... 3-12

3.2.13 Contamination Levels................................................................... 3-12

3.2.14 Waste Containers and Shipping Configuration .................................... 3-12

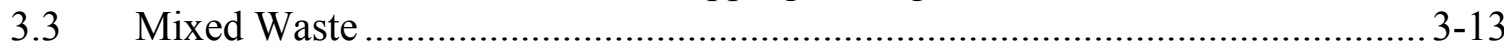

3.3.1 Acceptable Hazardous Waste Numbers ............................................. 3-13

3.3.2 Mixed Waste Treatment Notification....................................................... 3-14

3.3.3 Mixed Waste Profiles .................................................................... 3-14

3.3.4 Land Disposal Restrictions.............................................................. 3-14

3.3.5 Waste Form Criteria / Prohibited Items ………....................................... 3-14

3.3.6 MW Package Criteria ................................................................... 3-16

3.3.7 Analytical Data............................................................................. 3-17

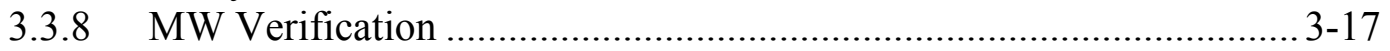

$3.4 \quad$ NNSSWAC Deviations..........................................................................

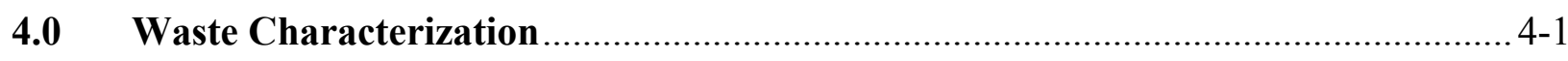

$4.1 \quad$ Process Knowledge .................................................................................... 4-1

4.2 Sampling and Analysis ........................................................................ 4-2

4.2.1 Data Validation............................................................................... 4-3

5.0 Quality Assurance Requirements for Waste Certification Programs …….............. 5-1

$5.1 \quad$ Program........................................................................................... 5-1

5.2 Personnel Training and Qualification ..............................................................5-2

5.3 Quality Improvement ............................................................................ 


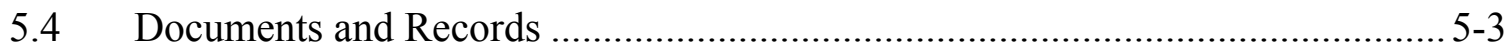

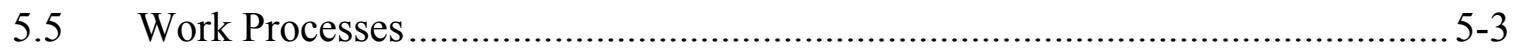

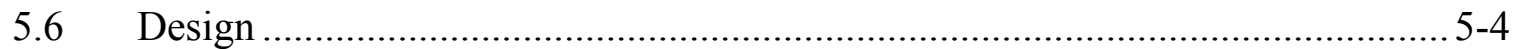

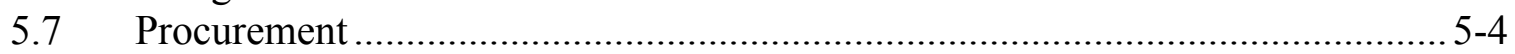

5.8 Inspection and Acceptance Testing .............................................................. 5-5

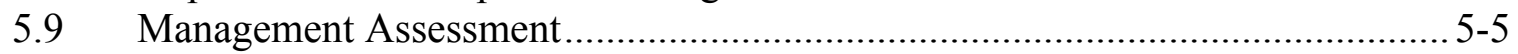

5.10 Independent Assessment .......................................................................... 5-5

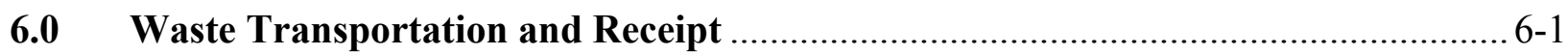

6.1 Shipment Scheduling and Limitations ......................................................... 6-1

6.2 Shipping Arrangements ……………………........................................... 6-1

6.2.1 Waste Receipt and Handling at NNSS .............................................. 6-1

6.2.2 Consignment of Shipments ............................................................. 6-2

6.2.3 Receiving Hours ................................................................................. 6-3

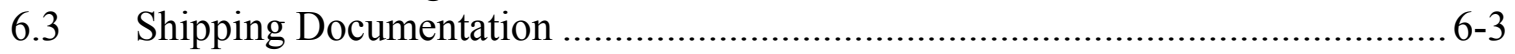

6.3.1 Accountable or Special Nuclear Material Shipments............................. 6-3

6.3.2 DOT-Regulated Shipments ……………….................................. 6-4

6.3.3 PSDR Submittal ..........................................................................

6.3.4 Additional Certification Statements ..................................................... 6-4

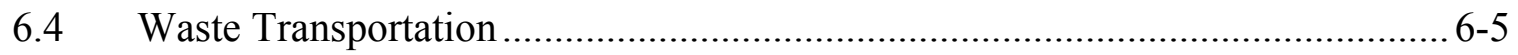

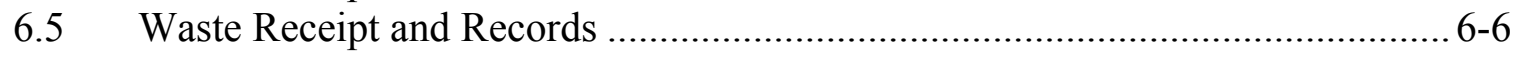

6.6 Funding and Forecasting ...............................................................................

6.7 Disposition of Noncompliant Conditions ………............................................ 6-6

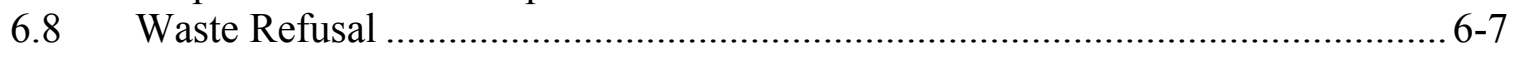

Appendix A - Waste Process Flow Diagram ……………................................... A-3 Appendix B - Plutonium Equivalent Gram (PE-g) Radionuclide Conversion Factors.. B-1

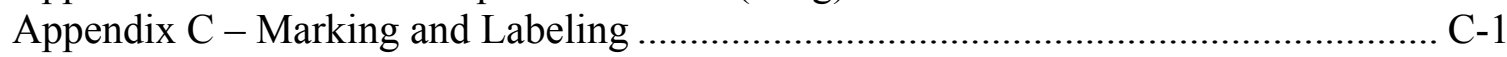

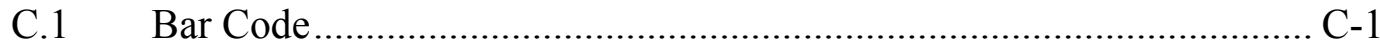

C.2 Marking and Labeling ..................................................................... C-2

C.3 Generator Waste Stream and Shipment Codes..................................... C-4

C.4 NTS Advance Shipment Notification................................................... C-5

Appendix D - Package Shipment Disposal Request ……………………………....... D-1

Appendix E - Radiological Waste Characterization and Reporting Requirements ........E-1

E.1 Radionuclide Reporting ................................................................................

E.2 Reserved to maintain section numbering.......................................................... E-3

E.3 Radiological Characterization Methods.........................................................

E.4 Determination of Waste Volume ……………....................................................

E.5 Examples of Waste Characterization Documentation ………………………......E-5

E.6 Radiological Characterization Flow Diagram Overview.....................................E-5

E.7 Fissile Material Limits ...................................................................................

Appendix F - Requirements for Intermodal (Roll-off boxes) LLW Disposal..................F-1

Appendix G - Mixed Waste Forms …………………...................................... G-1

Appendix H - Glossary ................................................................................... H-1

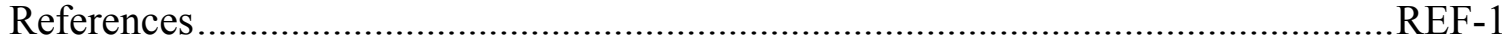




\section{List of Figures}

Figure C-1: Bar Code Label Example ..............................................................................

Figure C-2: Package Certification Label.........................................................................

Figure E-1: Radiological Characterization Flow Diagram .............................................. E-6

\section{List of Tables}

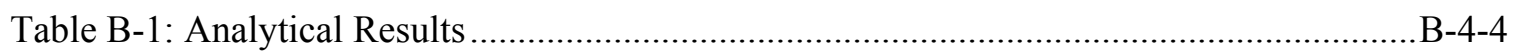

Table E-1: Radionuclide Action Levels for Waste Characterization and Reporting ....... E-2

Table E-2: Exempt Radionuclides …………………………………………………….... E-3

Table E-3: Calculation of ${ }^{235} \mathrm{U}$ Fissile Gram Equivalent and Effective ${ }^{235} \mathrm{U}$ Enrichment for LLW Packages ............................................................................. E-9

Table E-4: Allowable Package Fissile Loadings for Various Package Steel Weights .. E-10

Table E-5: Criticality Safety Restrictions for Use of Fissile Limits in Table E-6........... E-11

Table E-6: Maximum Grams of ${ }^{235} \mathrm{U}$ as a Function of Enrichment (controls as specified in Table E-5) ............................................................................ E-12 


\section{Acronyms}

ACM Asbestos-containing material

ALARA As Low as Reasonably Achievable

ALLW

Asbestiform Low-Level Waste

AMEM

Assistant Manager for Environmental Management

$\mathrm{Bq} \quad$ Becquerel

CAR Corrective Action Request

CFR Code of Federal Regulations

$\mathrm{Ci} \quad$ Curie

CSE Criticality Safety Evaluation

DET Determination of Equivalent Technology

DOE U.S. Department of Energy

DOT U.S. Department of Transportation

DQO Data Quality Objectives

EPA U.S. Environmental Protection Agency

ETA Estimated Time of Arrival

FGE Fissile Gram Equivalence

HEPA High-Efficiency Particulate Arresting

HRI Human Readable Interpretation

LDR Land Disposal Restrictions

LLW Low-Level Waste

M Manual, Mega

MC\&A Materials Control and Accountability

M\&TE Measuring and Test Equipment

MW Mixed Waste

MLLW $\quad$ Mixed Low-Level Waste

MWP Mixed Waste Profile(s)

NCSE Nuclear Criticality Safety Evaluation

NDEP Nevada Department of Conservation and Natural Resources, Division of

Environmental Protection

| NIC NNSSWAC Implementation Crosswalk

NNSA/NSO National Nuclear Security Administration Nevada Site Office

NRC U.S. Nuclear Regulatory Commission

NSTec National Security Technologies, LLC

NNSS Nevada National Security Site

NNSSWAC Nevada National Security Site Waste Acceptance Criteria 


\section{Acronyms (continued)}

PCB Polychlorinated Biphenyls

PCL Package Certification Label

PE-g Plutonium Equivalent Gram

PK Process Knowledge

PSDR Package Shipment Disposal Request

QA Quality Assurance

QAPP Quality Assurance Program Plan

RALLW Regulated Asbestos Low-Level Waste

RCRA Resource Conservation and Recovery Act

RTR Real-Time-Radiography

RWAP Radioactive Waste Acceptance Program

RWMC Radioactive Waste Management Complex

SSC Structures, Systems, and Components

SW-846 EPA Document SW-846, "Test Methods for Evaluation Solid Waste, Physical/Chemical Methods"

TID(s) Tamper-Indicating Device

TCLP Toxicity Characteristic Leaching Procedure

WAC Waste Acceptance Criteria

WARP Waste Acceptance Review Panel

WCO Waste Certification Official

WCPP Waste Certification Program Plan

WMP Waste Management Project

WP Waste Profile 


\subsection{Radioactive Waste Management at the Nevada National Security Site}

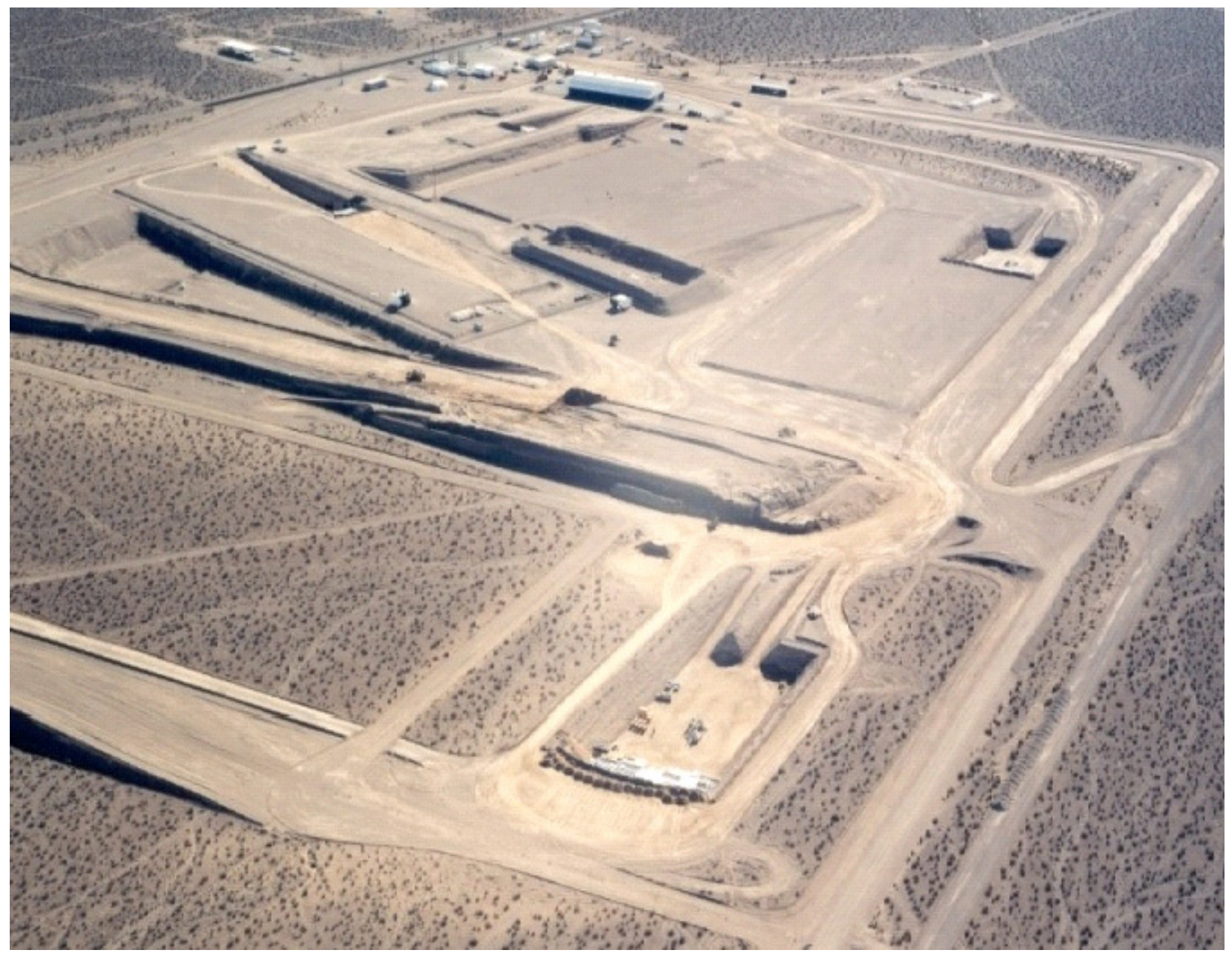

Area 5 Radioactive Waste Management Complex 
This page intentionally left blank. 


\subsection{Radioactive Waste Management at the Nevada National Security Site}

\subsection{Purpose and Scope}

This document establishes the U.S. Department of Energy (DOE), National Nuclear Security Administration Nevada Site Office (NNSA/NSO), Nevada National Security Site Waste Acceptance Criteria (NNSSWAC). The NNSSWAC provides the requirements, terms, and conditions under which the Nevada National Security Site (NNSS) will accept low-level radioactive waste (LLW) and mixed low-level waste (MLLW) for disposal.

The NNSSWAC includes requirements for the generator waste certification program, characterization, traceability, waste form, packaging, and transfer. The criteria apply to radioactive waste received at the NNSS Area 3 and Area 5 Radioactive Waste Management Complex (RWMC) for disposal.

The NNSA/NSO and support contractors are available to assist you in understanding or interpreting this document. For assistance, please call the NNSA/NSO Waste Management Project (WMP): at (702) 295-7063 or fax to (702) 295-1153.

\subsection{Policy}

\subsubsection{NNSA/NSO Policies}

- Ensure safe and compliant disposal of radioactive waste.

- Ensure consistency with the current revision of all applicable federal, state, and local regulations.

- Protect the environment, personnel, and public from chemical and radiological hazards in accordance with Title 40 Code of Federal Regulations (CFR), the Resource Conservation and Recovery Act (RCRA); Title 10 CFR 835, “Occupational Radiation Protection"; DOE Order 435.1, "Radioactive Waste Management"; and state of Nevada and applicable U.S. Department of Transportation (DOT) regulations.

- Ensure that present and future radiation exposures are kept as low as reasonably achievable (ALARA) and do not exceed the radiation protection standards established in Title 10 CFR 835, "Occupational Radiation Protection."

- Ensure that Quality Assurance (QA) programs are established and implemented to fulfill the requirements of DOE Order 435.1, "Radioactive Waste Management"; Title 10 CFR 830.122, "Quality Assurance"; and DOE Order 414.1, "Quality Assurance." 


\subsubsection{Process}

Waste will be accepted from generators approved by NNSA/NSO. The approval process is described in Section 2.0.

\subsubsection{Waste Type and Eligibility Determination}

Only DOE LLW and MLLW or U.S. Department of Defense classified wastes are accepted for disposal at the NNSS.

Waste streams shall have a "clear and unambiguous nexus" to a DOEfunded project, DOE-performed operation, DOE-owned material/waste, or project whose waste disposition is directed by statute. Documentation demonstrating the waste nexus to DOE or that it is being directed to DOE for disposal may be requested. To verify eligibility of proposed waste types, contact the NNSA/NSO WMP.

\subsubsection{Regulators and Stakeholders}

NNSA/NSO will facilitate appropriate oversight by state agencies and supports the involvement of stakeholders. Where appropriate, to the extent possible, and in accordance with applicable NNSA/NSO authority, NNSA/NSO will provide regulatory agencies and stakeholders access to information related to Nevada National Security Site Waste Acceptance Criteria (NNSSWAC) activities, including waste characterization data, from all generators. Upon request by such parties, arrangements may be made to observe NNSSWAC-related facility evaluations and participate in other activities such as NNSSWAC revisions.

\subsection{Requirements}

Requirements are identified by "shall." The source of requirements is identified by a superscript number that corresponds to the reference list at the end of this document. Unless otherwise stated, superscript references are to the latest edition and/or revision available for the respective documents. Statements not identified with a "shall" are provided as guidance. Section 2.0 requirements do not have corresponding references because the approval process is NNSA/NSO policy. Section 5.0 requirements are written in accordance with DOE Order 414.1, "Quality Assurance"; Title 10 CFR 830.122, "Quality Assurance"; and NNSA/NSO Policy, unless otherwise noted by superscript.

\subsection{Responsibilities}

The following offices and personnel have responsibilities for management and acceptance of radioactive waste at the NNSS. The offices identified are within the NNSA/NSO, unless otherwise stated. 


\subsubsection{Manager}

Responsibilities and authorities as assigned in DOE Order 435.1, "Radioactive Waste Management."

\subsubsection{Assistant Manager for Environmental Management (AMEM)}

Responsibilities and authorities as assigned in DOE Order 435.1 and implementation of the NNSA/NSO Radioactive Waste Management Program (RWAP) according to DOE Manual 435.1-1, "Radioactive Waste Management Manual." Approves waste generators to dispose or store radioactive waste at the NNSS and any deviations from the requirements of this document. Responsible for suspension of waste generator's waste certification programs, if necessary. AMEM responsibilities may be delegated with exception of generator waste certification program approvals and/or suspensions.

\subsubsection{Federal Project Director, Waste Management Project}

Responsible for radioactive waste management operation of the Areas 3 and 5 RWMC in compliance with applicable DOE Orders and federal and state regulations. Develop, implement, and maintain the NNSSWAC.

\subsubsection{Federal Sub-Project Director, Low-Level Waste Project}

Responsible for management of radioactive waste disposal operations at NNSA/NSO, and implementation of the RWAP program to ensure compliance with the NNSSWAC, DOE Orders, and federal regulations. Responsible for the management of MW disposal operations at NNSA/NSO.

\subsubsection{Radioactive Waste Acceptance Program Task Manager}

Responsible for interfacing with waste generators regarding RWAP program criteria and procedures, scheduling facility evaluations of waste generator programs, mixed waste verifications, maintaining RWAP quality records as defined by RWAP instructions, and initiating formal recommendations to the AMEM regarding the status of waste generator programs.

\subsubsection{RWAP Manager}

Responsible for coordinating and managing daily activities of the RWAP program and RWAP personnel. 


\subsubsection{RWAP Personnel}

Responsible for development, implementation, and maintenance of RWAP program documents (NNSSWAC, Work Instructions, Facility Evaluation records, etc.). Perform document reviews of waste generator program documents, waste profiles, and conduct of assessments of waste generators shipping radioactive waste to the NNSS. 


\subsection{Approval Process}

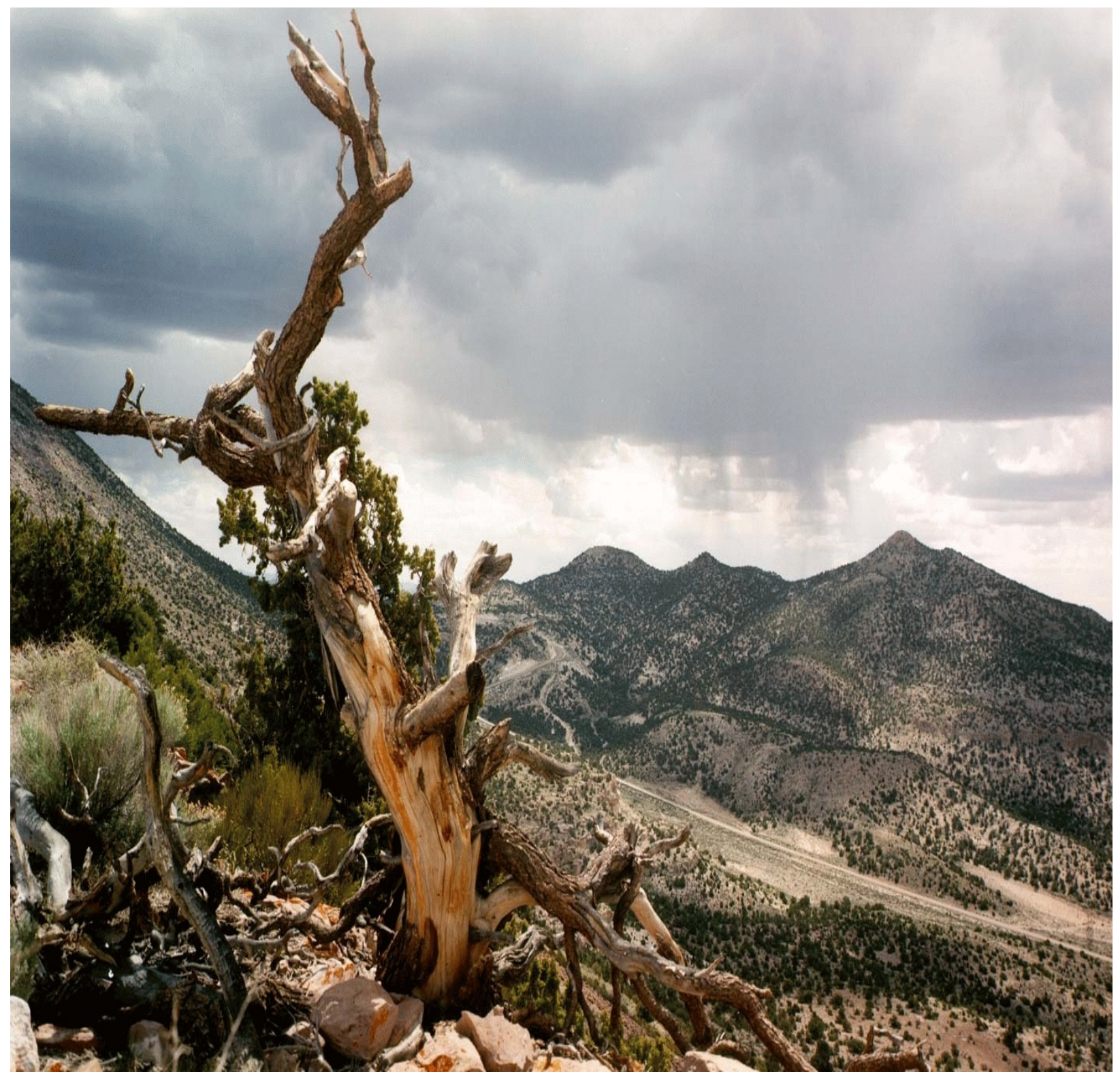

Bristlecone Pine, Rainer Mesa and Stockade Wash, Nevada National Security Site 
This page intentionally left blank. 


\subsection{Approval Process}

All waste offered for disposal shall be evaluated pursuant to DOE Order 435.1, "Radioactive Waste Management." The following describes the approval process and generator document requirements used by NNSA/NSO to verify that waste generators have a program in place to ensure that compliant waste is shipped to the NNSS.

A flow diagram of the approval process is provided in Appendix A.

\subsection{Generator Document Requirements}

Generators should contact NNSA/NSO WMP and verify that the proposed waste type can be accepted at the NNSS. Generators shall develop, implement, and maintain the program documents listed below. These documents describe the generators waste certification program and shall be submitted to the RWAP Manager as evidence of programmatic compliance. ${ }^{7.5}$

\subsubsection{Quality Assurance Program Plan}

A controlled copy of the site Quality Assurance Program Plan (QAPP) or NNSSWAC specific Waste Certification Program Plan (WCPP) shall be documented in accordance with Section 5.0 and issued to the RWAP Manager.7.5

\subsubsection{NNSSWAC Implementation Crosswalk}

The NNSSWAC Implementation Crosswalk (NIC) shall be prepared and submitted annually to RWAP in accordance with Section 5.0. ${ }^{7.5}$ An electronic copy of the NIC is available from the NNSA/NSO website at

http://www.nv.doe.gov/emprograms/environment/wastemanagement/rwap.aspx

\subsubsection{Waste Profiles}

A Waste Profile (WP) shall be prepared and submitted to NNSA/NSO for each waste stream proposed for disposal. The WP summarizes the waste form and characterization data, and shall include a list of referenced procedures, citing the number and title. The WP instructions, numbering, and format that shall be used are available from NNSA/NSO or on the NNSA/NSO website at

http://www.nv.doe.gov/emprograms/environment/wastemanagement/rwap.aspx ${ }^{7.5}$ 


\subsubsection{Certification Personnel List}

A current list identifying the site Waste Certification Official(s) (WCOs), Alternate WCO(s), and Package Certifier(s) shall be developed and submitted to RWAP in writing. ${ }^{7.5}$ The list shall include the name and telephone number of each individual authorized to certify waste packages and shipments. ${ }^{7.5}$ The WCO is responsible for maintaining the authorized certification personnel list and notifying RWAP, in writing, of any changes in personnel.

This information is used by RWMC personnel to verify signatures on the Package Certification Labels (PCLs) and to assure that shipments are from authorized personnel. Any packages or shipments certified by unauthorized personnel shall not be accepted at the RWMC. ${ }^{7.5}$

\subsubsection{Document and Personnel Changes}

Generators shall notify RWAP in writing of any changes to the generators QAPP or WCPP, waste profiles and/or key personnel. Controlled documents and/or revisions to documents may be submitted electronically to the RWAP Manager. Documents submitted in this manner shall be approved in accordance with the generator's program. The e-mail correspondence is maintained as the official record of transmittal for controlled documents.

Prior to implementation, the WCO shall immediately notify RWAP in writing of any critical process and/or procedure changes to the approved certification program. $^{7.5}$ Examples of critical processes and/or procedures include, but are not limited to, the following:

- Changes in inspection frequency;

- Changes in characterization methodology; and,

- Changes in training requirements.

Assistance in determining critical processes and/or procedures requiring written notification can be obtained from the RWAP Manager.

\subsection{RWAP Review}

The NNSA/NSO approval process for a generator's waste certification program and waste streams include a combination of on-site assessments and document reviews to verify continued program implementation. NNSA/NSO Corrective Action Requests (CARs) may be issued when conditions adverse to quality are identified. CARs require the generator to document a root cause, corrective action, and action to preclude recurrence. Failure to respond to CARs, in a timely manner, could lead to delays in approval or result in a program or waste stream suspension in accordance with Section 2.4. 


\subsubsection{Facility Evaluations}

Facility evaluations (audits, surveillances) are scheduled and conducted by RWAP.

Audit

New generators shall submit the documents described in Section 2.1 to RWAP prior to scheduling their initial audit. ${ }^{7.5}$ Discretionary programmatic audits of approved generators may be conducted as directed by NNSA/NSO.

The purpose of an audit is to examine and evaluate objective evidence to verify that program documents contain the necessary elements and are adequately implemented. The audit scope will include an on-site evaluation of the characterization, QA, and waste traceability program elements. Audits are both programmatic and performance-based evaluations.

\section{Surveillance}

Scheduled or unscheduled surveillances may be performed to evaluate specific program elements, new waste streams, and verify implementation of corrective actions.

\subsubsection{Waste Profiles}

Waste Profiles (WPs) shall be submitted to RWAP for review through the Waste Acceptance Review Panel (WARP) process. ${ }^{7.5}$ The WARP may require additional information from the generator, recommend surveillance, or NNSA/NSO approval or a suspension of the waste stream.

New generators shall complete and submit at least one profile to RWAP for review prior to the initial audit of their waste certification program. ${ }^{7.5}$

WPs for new waste streams or changes to approved waste streams may be submitted to RWAP for review by the WARP at any time. When WPs are revised, depending on the significance of the revision, authorization for continued shipping under the current approved WP may be suspended until the changes have been reviewed and accepted.

Generators should provide written responses to WARP comments within 90 days of comment submittal to ensure continued processing of WPs. If responses are not received within 90 days, review of the WP may be terminated.

The WCO shall perform a documented annual review of NNSS approved LLW WPs, based on the current revision date of each profile, to ensure the characterization data, waste stream information, and referenced procedures are 
current. $^{7.5}$ For annual recertification of Mixed Waste Profiles (MWP), refer to Section 3.3.3.

Generators shall notify RWAP in writing when terminating an approved WP (project is complete, one-time-only waste stream and has been shipped, etc.). ${ }^{7.5}$ WPs and/or revisions may be submitted electronically in accordance with Section 2.1.5.

\subsubsection{Split Sampling}

The purpose of the split sampling program is to verify the results of waste analysis. NNSA/NSO may select a waste stream for split sampling based on its annual volume, the potential for finding hazardous components, or the scope and complexity of the sampling process to be performed. NNSA/NSO may require split sampling prior to the waste stream being approved.

Samples will be collected by the generator's sampling team under the observation of an RWAP representative. NNSA/NSO may split a representative waste sample with the generator for independent analysis. Samples will be sent to the generator laboratory and to an independent laboratory chosen by NNSA/NSO. The samples will be analyzed by the same analytical methods. Results of analyses from both laboratories will be compared by RWAP after data validation. Differences between the two sets of data may require further investigation.

\subsection{Approval}

Waste Certification Program approval is granted by the NNSA/NSO AMEM after the generator has demonstrated satisfactory implementation of the NNSSWAC. Factors considered in determining approval include, recommendations from RWAP, results of facility evaluations, review of program documents, waste profiles and procedures, and generator readiness.

NNSA/NSO will provide written notice of program approval, identifying the last facility evaluation number, current program document (QAPP or WCPP) and revision, and approved waste profile(s). Any special conditions affecting the program or waste profile approval will also be identified.

Approved waste generators shall ensure the following documents are maintained current within RWAP while their approval to ship waste is in effect: ${ }^{7.5}$

- Approved list of Authorized Certification Personnel

- Latest approved WP (Active WPs Only)

- Controlled copy of their site QAPP

- NIC 


\subsection{Suspending Approval}

NNSA/NSO may suspend approval if generator's waste or documents do not meet NNSSWAC requirements. Individual waste streams or the generator's entire waste certification program may be suspended. Suspension may be issued verbally by NNSA/NSO representatives, followed by official written notification. Reasons for suspension may include, but are not limited to:

- Improper manifesting (e.g., incorrect nuclide inventory or activity level reported),

- Repetitive programmatic deficiencies,

- Incorrect waste characterization,

- Waste container integrity deficiencies,

- Inadequate nuclear criticality safety limits, and

- Facility evaluation results.

\subsection{Technical Support}

NNSA/NSO provides qualified technical assistance on NNSSWAC issues at no cost to the generator. Generators wanting an independent review and one-on-one consulting on issues regarding their low-level waste and/or low-level mixed waste management program are encouraged to contact NNSA/NSO. NNSA/NSO assistance to waste generators includes:

- Gap-analysis site visits

- Policy and regulatory interpretations

- Waste packaging and transportation issue assistance

For additional information on requesting technical support, contact the NNSA/NSO RWAP Task Manager.

\subsection{NNSA/NSO Policy}

Because of changes in regulatory requirements, NNSS policies, and changes instituted as a result of lessons learned, any aspect of the waste certification process may be subject to a full review to ensure its compliance with any changed requirements and effectiveness. This review may entail imposing additional requirements or reversing previous decisions. Unannounced facility evaluations may be performed at the discretion of NNSA/NSO. 
This page intentionally left blank. 


\subsection{Waste Criteria}

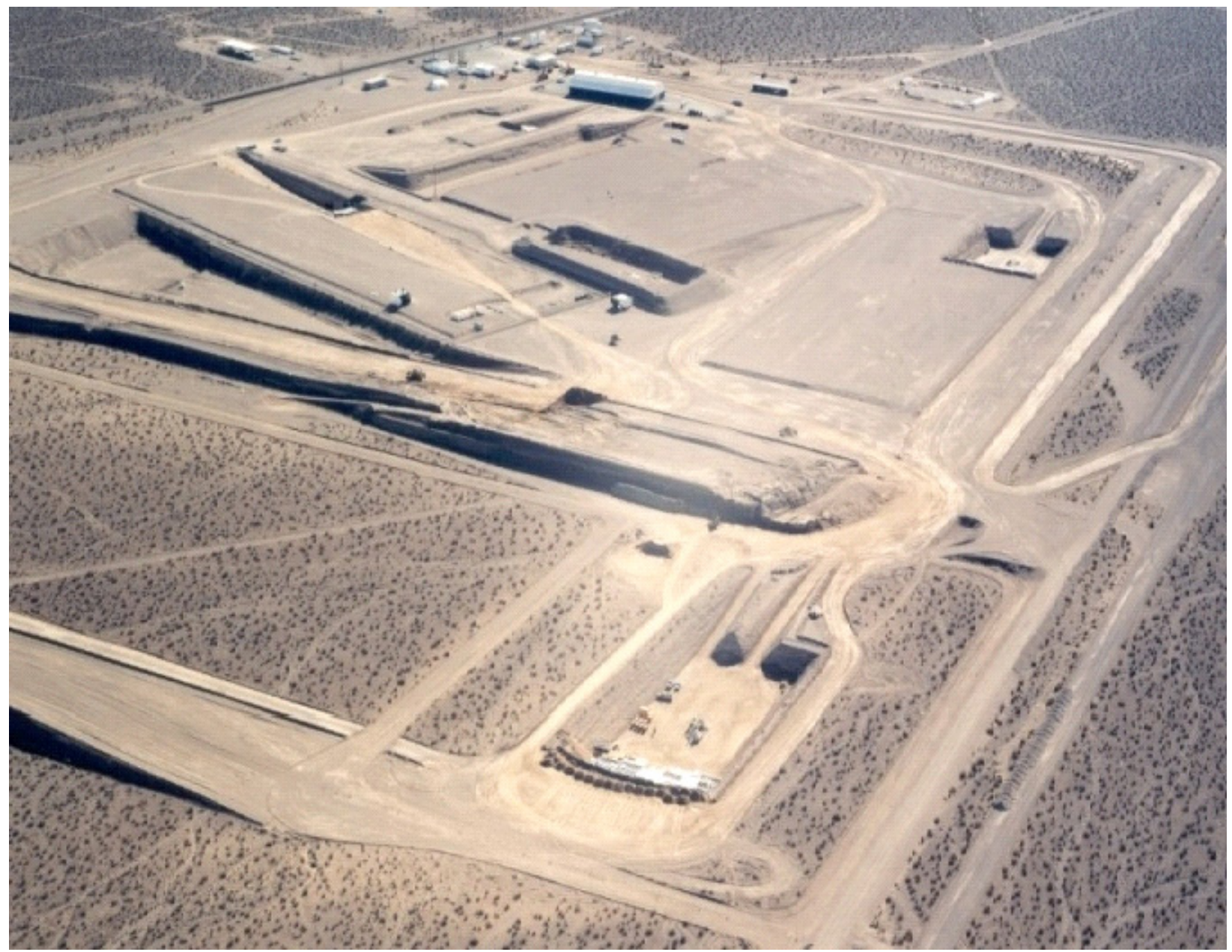

Area 5 Radioactive Waste Management Complex, Nevada National Security Site 
This page intentionally left blank. 


\subsection{Waste Criteria}

Waste accepted at the NNSS shall be radioactive and shall meet the waste criteria outlined below. ${ }^{6.6}$ Generators shall ensure that waste is handled, stored, and shipped in accordance with applicable DOE, DOT, U.S. Environmental Protection Agency (EPA), state, and local regulations and requirements. Waste streams deviating from these requirements will be evaluated in accordance with Section 3.4, NNSSWAC Deviations. $^{7.5 / 6.15}$

\subsection{General Waste Form Criteria}

These waste criteria are based on DOE radioactive waste management policies and practices.

\subsubsection{Transuranics}

The concentration of alpha-emitting transuranic nuclides with half-lives greater than 20 years shall not exceed $100 \mathrm{n}$ curie $(\mathrm{Ci}) / \mathrm{g} .{ }^{6.5}$ The net weight of the waste (excluding the weight of the container and shielding) shall be used to calculate the specific activity of the waste in each container. ${ }^{7.5}$ The following isotopes shall be considered when making the transuranic waste determination: ${ }^{237} \mathrm{~Np}$, ${ }^{238} \mathrm{Pu},{ }^{239} \mathrm{Pu},{ }^{240} \mathrm{Pu},{ }^{242} \mathrm{Pu},{ }^{244} \mathrm{Pu},{ }^{241} \mathrm{Am},{ }^{242 \mathrm{~m}} \mathrm{Am},{ }^{243} \mathrm{Am},{ }^{243} \mathrm{Cm},{ }^{245} \mathrm{Cm},{ }^{246} \mathrm{Cm}$, ${ }^{247} \mathrm{Cm},{ }^{248} \mathrm{Cm},{ }^{250} \mathrm{Cm},{ }^{247} \mathrm{Bk},{ }^{249} \mathrm{Cf},{ }^{251} \mathrm{Cf}$. Additional information on determining the transuranic alpha concentration can be found in the document "Determining Transuranic Alpha Activity Concentration for Compliance with NNSSWAC" located at the web address:

http://www.nv.doe.gov/emprograms/environment/wastemanagement/rwap.aspx ${ }^{6.4}$

\subsubsection{Radionuclide Content or Concentration}

Radionuclide concentration shall be reported in accordance with Appendix E, "Radionuclide Characterization and Reporting Requirements." 6.7/6.16/6.18 Radionuclide limits for disposal are listed in Table E-1, "Radionuclide Action Levels for Waste Characterization and Reporting." Waste having radionuclide concentrations above these limits may be acceptable for disposal upon review by NNSA/NSO, provided the content does not exceed the package activity limits identified in Section 3.2.2.

\subsubsection{Reserved to maintain section numbering.}

\subsubsection{Hazardous Waste}

Waste regulated solely under Title 40 CFR 261-268 and state of Nevada 
hazardous waste regulations shall not be accepted for disposal. ${ }^{3.3 / 5.4}$ State of Nevada regulations require that waste regulated as hazardous in the state of generation shall be regulated as hazardous when brought into the state of Nevada; therefore, such waste shall not be accepted for disposal. ${ }^{5.3}$ For MW, see Section 3.3 .

Environmental media from cleanup activities may be acceptable for disposal if:

The state of origin makes a "Contained-In Determination" for LLW environmental media that was in contact with "listed" wastes. The generator shall submit this determination to NNSA/NSO for evaluation, and provide and demonstrate: ${ }^{7.5}$

- Documentation that the waste is primarily environmental media (not debris). For the purpose of this determination, environmental media is defined as materials found in the natural environment such as soil, groundwater, surface water, and sediments; or a mixture of such with liquids, sludges, or solids, which are inseparable by simple mechanical removal processes;

- Documentation that the media was representatively sampled and evaluated for total contaminant concentrations $(\mathrm{mg} / \mathrm{kg})$ and Toxicity Characteristic Leaching Procedure (TCLP) concentrations (mg/L) where applicable;

- If the treatment standard is provided in " $\mathrm{mg} / \mathrm{kg}$ " (totals), the "listed" constituents shall be less than one-tenth of the concentration of the RCRA Land Disposal Restriction (LDR) (Title 40 CFR 268.40). If the treatment standard is provided in "mg/l TCLP," the TCLP concentration shall be less than the Safe Drinking Water Act Standard (MCL).

- Laboratory data including QA/Quality Control data.

The Nevada Department of Conservation and Natural Resources, Division of Environmental Protection (NDEP) will evaluate the state of origin "Contained-In Determination" on a case-by-case basis for concurrence and will issue written correspondence through the WARP process once the generator has provided and demonstrated the above-stated items.

Debris contaminated with "listed" constituents will be evaluated, independent of the criteria established above for environmental media.

\subsubsection{Free Liquids}

Liquid waste and waste containing free liquids shall be converted into a form that contains as little free-standing and noncorrosive liquid as is reasonably achievable. ${ }^{6.11}$ Liquid waste and waste containing free liquids should be processed to a solid form or packaged in sufficient sorbent for twice the volume 
of the liquid. The free liquid shall not exceed 1 percent of the volume of the waste when the waste is in a disposal container; or 0.5 percent of the volume of the waste processed to a solidified form. ${ }^{6.11}$ Provisions for additional sorbent should be made when significant temperature and atmospheric differences exist between the generating site and the disposal site.

Waste shall be evaluated to determine its potential to release liquid during handling, storage, and transportation. ${ }^{7.6}$ High moisture content waste is defined as waste that has the potential to release moisture from its final waste form in excess of the NNSSWAC requirement. Generators shall document the decisions made when characterizing and determining sorbents for high moisture content waste (see the Nevada National Security Site Generator Work Group "Position Paper for High Moisture Content Waste," Revision 0, dated 11/3/1998, for use as guidance located at

http://www.nv.doe.gov/emprograms/environment/wastemanagement/rwap.aspx

\subsubsection{Particulates}

Fine particulate wastes shall be immobilized so that the waste package contains no more than 1 weight percent of less-than-10-micrometer-diameter particles, or 15 weight percent of less-than-200-micrometer-diameter particles. ${ }^{7.6}$ Waste known to be in a fine particulate form or in a form that could mechanically or chemically be transformed to a particulate during handling and interim storage shall be immobilized. ${ }^{7.6}$

Secure packaging may be used in place of immobilization. The following are examples of acceptable packaging: steel boxes, drums with a sealed 6 mil minimum (or equivalent) liner, containers with contents individually wrapped and sealed in plastic, and over-packed containers.

\subsubsection{Gases}

LLW gases shall be packaged at a pressure that does not exceed 1.5 atmospheres absolute at $20^{\circ} \mathrm{C} .^{6.14 / 7.6}$ Compressed gases as defined by Title 49 CFR shall not be accepted. ${ }^{7.6}$ Examples of compliance methods include puncturing aerosol cans and removing the valve mechanism from expended gas cylinders.

\subsubsection{Stabilization}

Where practical, waste shall be treated to reduce volume and provide a more stable waste form. ${ }^{6.23}$ Wastes shall not react with other wastes or the packaging during storage, shipping, handling, and disposal. ${ }^{6.8}$

Structural stability can be accomplished by crushing, shredding, or placing a smaller piece inside an opening of a larger piece, such as nesting pipes. 
Chemical stability and compatibility shall be demonstrated to ensure that no reactions occur and significant quantities of harmful gases, vapors, or liquids are not generated ${ }^{6.13}$ (specifically when different waste forms are combined in a single waste container).

\subsubsection{Etiologic Agents}

LLW containing pathogens, infectious wastes, or other etiologic agents as defined in Title 49 CFR shall not be accepted. ${ }^{7.6}$

\subsubsection{Chelating Agents}

LLW packages containing chelating or complexing agents in amounts greater than 1 percent of the waste shall not be accepted unless stabilized or solidified. ${ }^{6.9 / 7.6}$

\subsubsection{Polychlorinated Biphenyls}

LLW containing Polychlorinated Biphenyls (PCBs) that meet the requirements for disposal in a solid waste or permitted hazardous waste landfill as specified in 40 CFR Part 761 and NAC 444.9452 shall be accepted.

PCB contaminated LLW shall be packaged, marked, and labeled in accordance with the requirements of Title 40 and Title $49 \mathrm{CFR}^{3.22 / 4.3}$ and meet applicable shipping requirements for the radioactive content of the package. LLW containing PCBs that meet the requirements for disposal in a permitted hazardous waste landfill shall be segregated into a separate waste stream and profiled and packaged separately from other waste streams. ${ }^{8.0}$ These types of PCB wastes shall also meet requirements listed in Section 3.3.5 and 3.3.6.2. ${ }^{8.0}$

Generators shall provide written notice, a minimum of 15 days, in advance of the first shipment of each waste stream containing PCB remediation waste or bulk product waste. $^{3.21}$ The notice shall be submitted to the RWMC via fax (702) 295-6852 or e-mail towminfo@nv.doe.gov and should contain information specified in 40 CFR 761.61 for PCB remediation waste and/or 40 CFR 761.62 for PCB Bulk Product Waste.

\subsubsection{Explosives}

Waste containing un-reacted explosives shall not be accepted at the NNSS. Such waste may have RCRA characteristics and shall be treated to meet LDRs before being acceptable for disposal at the NNSS. ${ }^{6.12}$ 


\subsubsection{Pyrophorics}

Pyrophoric materials contained in the waste shall be treated, prepared, and packaged to be nonflammable. ${ }^{6.12}$ Pyrophoric materials that are blended in a hardened concrete matrix are considered to be treated to be nonflammable.

\subsubsection{Sealed Sources}

Sources containing transuranic nuclides shall be individually evaluated against the transuranic criteria (Section 3.1.1), considering only the mass of the source and any component integral to the source. ${ }^{7.3}$

Sealed sources that have an activity of less than 3.7 Mega (M) Becquerel(s) (Bq) $(100 \mu \mathrm{Ci})$ can be a component of waste streams such as contaminated trash. The total volume of the waste can be used for waste classification and for determination of the radionuclide concentration. Characterization of nontransuranic sources (i.e., less than $3.7 \mathrm{MBq}[100 \mu \mathrm{Ci}]$ ) on an individual source basis is not required, if the characterization method used is adequate to ensure compliance with the radionuclide reporting criteria.

Sealed sources that have an activity of $3.7 \mathrm{MBq}(100 \mu \mathrm{Ci})$ or greater shall be segregated from other waste and profiled as a separate waste stream. ${ }^{7.3}$ These sealed sources shall be characterized on an individual basis using the volume or mass of the source to determine the radionuclide concentration ${ }^{7.3}$ Sealed sources may be co-packaged with other waste streams provided Section 3.0, Waste Criteria, are met.

Additional guidance on the definition, proper packaging, and characterization of sealed sources can be found in the "Position Paper on the Proper Characterization and Disposal of Sealed Radioactive Sources," located at the web address below:

http://www.nv.doe.gov/emprograms/environment/wastemanagement/rwap.aspx

\subsubsection{Low-Level Waste Containing Regulated Asbestos}

Regulated Asbestos Low-Level Waste (RALLW) is defined as any LLW containing friable asbestos material; Category I nonfriable asbestos-containing material (ACM) that has become friable; Category I nonfriable ACM that will be or has been subjected to sanding, grinding, cutting, or abrading; or Category II nonfriable ACM that has a high probability of becoming or has become crumbled, pulverized, or reduced to powder. RALLW shall be packaged, marked, and labeled in accordance with the requirements of Title 40 CFR, State of Nevada Solid Waste Disposal Site Permit (SW1300001, current revision), state-ofgeneration, and the NNSS Management Plan for the Disposal of Low-Level Waste with Regulated Asbestos Waste, current revision. ${ }^{7.2}$ Packages containing RALLW shall meet the applicable shipping requirements for the radioactive 
contents of the package. ${ }^{4.5}$ RALLW shall be wetted with a water and surfactant mixture and packaged in a plastic bag that is not less than 6 mil in thickness, a combination of plastic bags that equal 6 mil in thickness, or a container that is lined with plastic. ${ }^{5.1}$

If free liquid is present, sorbent shall be added to ensure compliance with the free-liquids criteria. ${ }^{6.11}$ Sharp edges and corners in the package shall be padded or protected to prevent damage to the plastic bag during handling, shipping, and disposal. ${ }^{7.6}$

Each container used to dispose RALLW shall bear a label that contains one of the statements below. ${ }^{5.2}$

\begin{tabular}{|c|}
\hline \multicolumn{2}{|c|}{ (1) CAUTION } \\
CONTAINS ASBESTOS FIBERS \\
AVOID OPENING OR BREAKING CONTAINER \\
BREATHING ASBESTOS IS HAZARDOUS TO YOUR HEALTH \\
\hline $\begin{array}{c}\text { (2) CAUTION CONTAINS ASBESTOS } \\
\text { FIBERS AVOID CREATING DUST } \\
\text { MAY CAUSE SERIOUS BODILY } \\
\text { HARM }\end{array}$ \\
$\begin{array}{c}\text { (3) DANGER CONTAINS ASBESTOS FIBERS } \\
\text { AVOID CREATING DUST }\end{array}$ \\
\hline
\end{tabular}

RALLW shall be profiled and segregated into a separate waste stream. ${ }^{7.9}$ Because of state notification requirements and disposal cell capacity, RALLW shall be packaged separately from other waste streams. ${ }^{7.2}$ RALLW shall not be packaged into soft-sided containers as the only containment. ${ }^{7.2}$ Contact NNSA/NSO WMP at (702) 295-7063 for assistance or to obtain a copy of the current NNSS Management Plan for the Disposal of Low-Level Waste with Regulated Asbestos Waste, which includes specific requirements for pre-shipment notifications. Pre-shipment notifications shall be faxed (702-295-1153) to NNSA/NSO at least seven (7) days prior to shipment arrival. ${ }^{7.5}$ A signed copy of the notification will be returned to the generator indicating authorization of the shipment.

\subsubsection{Radioactive Animal Carcasses}

Animal carcasses containing, or contained in, radioactive materials shall be packaged with the biological material layered with lime and placed in a metal container meeting applicable requirements. ${ }^{1.1 / 1.2 / 7.6}$ If the resultant waste matrix is capable of gas generation, the container shall be vented with a carbon composite High-Efficiency Particulate Air (HEPA) filtration device. 1.1/7.6 NNSA/NSO may require analysis of the waste decomposition gases. Animal carcasses preserved with formaldehyde shall not be accepted for disposal. ${ }^{7.6}$ 


\subsubsection{Beryllium Waste}

For this section, beryllium is defined as elemental beryllium and any insoluble beryllium compound or alloy containing 0.1 percent beryllium or greater that may be released as an airborne particulate. Beryllium-containing waste and berylliumcontaminated equipment shall be packaged in sealed, impermeable bags (minimum $6 \mathrm{mil}$ ), containers, or enclosures to prevent the release of beryllium dust during handling and transportation. ${ }^{1.4 / 7.6}$ The bags, containers, and enclosures shall be labeled with the following information: ${ }^{1.5}$

"DANGER, CONTAMINATED WITH BERYLLIUM
DO NOT REMOVE DUST BY BLOWING OR SHAKING
CANCER AND LUNG DISEASE HAZARD"

\subsubsection{Classified Waste}

Generators are responsible for ensuring requirements of DOE Manual 470.4-4, "Information Security," Section A, Chapter III -3 and 4 are satisfied for permanent burial of classified waste at NNSS. ${ }^{6.3}$ Generators shall submit a signed DOE or NNSA Security Authorization for permanent burial without sanitization with their classified waste profile. ${ }^{7.5}$ This approval does not replace or eliminate the Material Control and Accountability requirements of Section 6.3.1.

Classified waste (LLW or MLLW) shall be profiled and segregated into a separate waste stream. ${ }^{7.6}$ Generator's shipping classified waste that requires protection from visual observation, shall submit the "Advance Shipment Notification" form, identified in Appendix C.4, to the RWMC at least seven (7) days prior to shipment arrival. $^{7.6}$ This form can be forwarded via fax at (702) 295-6852 or e-mail to wminfo@nv.doe.gov.

\subsubsection{Petroleum Hydrocarbon Burdened LLW}

Petroleum hydrocarbon burdened LLW soil and closely related construction and demolition debris, greater than $100 \mathrm{mg} / \mathrm{kg}$ Total Petroleum Hydrocarbons (TPH), resulting from a petroleum release generated by NNSA/NSO Operations will be disposed at the RWMC. The concentration level of TPH is measured using U.S. EPA Method 8015, modified.

NTS generated hydrocarbon waste shall be packaged separately from other LLW, the containers identified as "HYDROCARBON WASTE" near the bar code labels, and shipped under separate shipping documents (Bill of Lading, Shipping Manifest, Package Shipment Disposal Request, Certification Statement, etc.). ${ }^{7.2}$ 


\subsection{Waste Package Criteria}

Waste packages shall meet applicable DOE Orders, Title 10 CFR, Title 40 CFR, and Title 49 CFR requirements such as design, nuclear safety, radiation levels, activity limits, nuclear heating, and multiple hazards. Waste packages shall be capable of withstanding the stresses associated with the loading, handling, stacking, and shipping of the package. ${ }^{4.4}$ NNSA/NSO has adopted the following waste package criteria to assure that the NNSS RWMC is operated safely and efficiently:

\subsubsection{Nuclear Criticality Safety}

The quantity of fissile (fissionable) material in a waste package shall be limited so that an infinite array of such packages will be subcritical under "as packaged" conditions and if the array were to be flooded with water to any credible degree. $^{6.2 / 7.14}$ Waste packages shall comply with the fissile material limits in Appendix E. ${ }^{7.5}$ Compliance of a waste package with the fissile material limits is required to be documented in the WP.

\subsubsection{Package Activity Limitations}

Package Activity limits at NNSS are based on Plutonium 239 Equivalent-grams (PE-g). The total PE-g for either a waste package or a shipment shall be calculated by multiplying the activity of each radionuclide by the PE-g conversion factor (Appendix B) and then adding each radionuclide PE-g to get the total PE-g.

The PE-g limit for all waste packages (e.g., drums, boxes, soft-sided packages, bulk or wrapped objects) is 300 PE-g total, except for DOT Type B containers, for which there is no limit as long as the DOT Type B container is also the disposal container.

The PE-g limit for a shipment is 2000 PE-g total. Any shipment that has a package that exceeds the package limit will be refused for disposal. Any shipment that exceeds the shipment limit will be refused for disposal.

\subsubsection{Closure}

Waste package closures shall be designed to ensure they will withstand the effects of changing temperatures, weather, pressures, and/or vibrations under normal handling and shipping conditions and not breach or lose the package contents. ${ }^{4.5}$

\subsubsection{Lead Shielding}

The use of lead for shielding (radioactively contaminated or radioactively uncontaminated) in containers for the disposal of LLW is an acceptable practice. Generators shall maintain the following: 
- Documentation demonstrating that standard packaging without lead shielding would not reduce the exposure rate to less than $0.005 \mathrm{rem} / \mathrm{hr}(5 \mathrm{mrem} / \mathrm{hr})$ at 30 centimeters and the shielding is necessary for radiation protection; and,

- Documentation demonstrating that the amount of lead used for shielding is not excessive for each specific container of LLW. The documentation shall include calculations demonstrating the amount of lead (thickness/quantity) in the container is not excessive by justifying the quantity of lead required in each given container on a container-by-container basis. Justification for using the appropriate amount of lead shielding can be demonstrated by a detailed dose rate survey that shows the shielded dose rate exceeds $0.005 \mathrm{rem} / \mathrm{hr}$ at 30 $\mathrm{cm}$ from the waste package. ${ }^{7.12}$

Additional information on the use of lead shielding can be found in the "Position Paper on the Use of Lead Shielding for the Disposal of Low Level Waste at the NNSS," located at the following web address:

http://www.nv.doe.gov/emprograms/environment/wastemanagement/rwap.aspx

\subsubsection{Strength}

The disposal package (packaging and contents) shall be capable of supporting a uniformly distributed load (compressive strength) of $16,477 \mathrm{~kg} / \mathrm{m}^{2}(3,375$ $\left.\mathrm{lbs} / \mathrm{ft}^{2}\right)^{7.4}$

This is required to support other waste packages and earth cover without crushing during stacking and covering operations. Actual physical testing or design engineering calculations may be used to demonstrate compliance.

This requirement does not apply to bulk waste (e.g. supersacks, burrito wraps, unpackaged waste items), waste packaged in steel drums, high integrity containers, cargo transport containers, or roll-off containers. These containers shall be sufficiently strong to ensure they will not breach under normal offloading conditions. ${ }^{7.6}$

Bulk waste containers with a reasonable probability of breaching during offloading (i.e., burrito wraps), regardless of the type of transport vehicle (i.e., intermodals), shall meet the package activity limitations of Section 3.2.2. . $^{\text {. }}$ Alternative packaging will be evaluated for approval on a case-by-case basis dependent on waste stream characteristics. Refer to NNSSWAC Section 3.2.14 for additional information.

\subsubsection{Handling}

Waste packages that require remote handling may incur additional cost for the generator and delay waste profile approval. Packages exceeding $1 \mathrm{mSv} / \mathrm{hr}$ 
$(100 \mathrm{mR} / \mathrm{hr})$ dose rate at 30 centimeters shall be considered for remote handling. ${ }^{7.6}$ Handling procedures and ALARA documentation shall be referenced on the WP for wastes requiring remote handling and made available to the disposal site upon request. ${ }^{7.6}$

Waste packages shall be provided with cleats, offsets, rings, handles, permanently attached or removable skids, or other auxiliary lifting devices to allow handling by means of forklifts, cranes, or similar handling equipment. ${ }^{7.6}$ All waste packages requiring cranes for off-loading shall have an approved lift plan

generated by NNSS RWMC prior to shipment. ${ }^{7.6}$ Additional costs incurred by development and implementation will be the responsibility of the waste generator.

Waste packages with permanently attached lifting devices are permissible, provided they are recessed, offset, or hinged in a manner that does not inhibit stacking the packages. Auxiliary lifting devices for any portion of the package extending from the top of the waste package shall be no higher than 0.1 meter (4 inches) in normal position. ${ }^{7.6}$ Lifting devices shall be designed in accordance with the DOE Hoisting \& Rigging Manual, DOE-STD-1090-Current Publication. ${ }^{7.1}$

Lifting devices that are a structural part of the package shall be designed with a minimum safety factor of three-to-one against yielding when used to lift the package to ensure any failure of a lifting attachment under excessive load would not impair the integrity of the package. Any other structural part of the package which could be used to lift the package shall be capable of being rendered inoperable for lifting the package during transport or shall be designed with strength equivalent to that required for lifting attachments. ${ }^{4.4}$

Rigging devices (e.g., slings, spreader bars, rings, hooks) not permanently attached to the waste package that are provided by the generator for off loading shall have a current load test based on the requirements of the DOE Hoisting \& Rigging Manual, DOE-STD-1090-Current Publication. ${ }^{7.1}$ Non-permanently attached rigging devices shall have traceable certifications provided with the shipping documents. ${ }^{7.6}$ They shall not show any signs of corrosion, kinking, birdcaging, or other deterioration. ${ }^{7.6}$

LLW packages that have abnormal centers of gravity shall be clearly marked with the center of gravity. ${ }^{7.6}$ Top-heavy loads are severely discouraged, and bulk waste shipments with complex geometries shall be loaded in the most stable configuration. ${ }^{7.6}$ Cargo containers are exempted from this requirement until the gross weight exceeds 30,000 lbs. 


\subsubsection{Size}

Waste containers / packages that allow for optimum handling and stacking efficiency in disposal cells should be considered for use (i.e., cargo containers, boxes measuring $4 \times 4 \times 7 \mathrm{ft}$ or $4 \times 2 \times 7 \mathrm{ft}$, or 55/85-gallon drums).

Alternate packages (e.g., super-sacks, burrito wraps) will be considered; however, RWMC operations personnel need to be consulted to ensure equipment compatibility. MW, "Classified Waste," RALLW, PCBs, or Low-Level Hydrocarbon-Burdened waste that is not packaged in hard-sided containers meeting the strength requirement, allowing the packages to be stacked at least 14 feet high in a safe and stable manner, may incur additional handling costs.

Bulk waste generally exists in a form not suited to the conventional packaging requirements. Bulk LLW shall meet the requirements of Title $49 \mathrm{CFR} .^{4.7}$ Large items of bulk waste, such as machinery, may be considered for disposal unpackaged. For the transfer of unpackaged bulk material having external contamination, the contamination shall be fixed, covered, or contained sufficiently for safe transfer. ${ }^{4.8}$

Refer to Appendix F for specific packaging requirements and limitations for intermodal (Roll-off boxes) containers to be returned to the generator. All other types of containers that are requested to be returned will be evaluated on a caseby-case basis during the waste profile review process. The request that containers be returned should be identified in the special-handling section of the waste profile. The return of bulk containers may incur additional operational costs.

\subsubsection{Weight}

Weight limits for final waste packages shall not exceed the approved packaging design or NNSS limits of 4,082 $\mathrm{kg}(9,000 \mathrm{lbs})$ per box and $544 \mathrm{~kg}(1,200 \mathrm{lbs})$ per drum. $^{2.1}$ These weight limits do not apply to bulk wastes.

Exception to the specified box weight limit is allowed if the following requirements are satisfied:

- Final weight shall not exceed the approved manufacturer design limits;

- Final weight of MLLW shall not exceed the NNSS RTR weight capacity of 11000 lbs;

- Each overweight box shall be clearly marked "Overweight Box," and

- Shipped on a flatbed trailer and cribbed to a 4-inch minimum height to allow offloading with a forklift.

\subsubsection{Loading (Void Space)}

Waste packages shall be loaded to ensure that the interior volume is as efficiently 
and compactly loaded as practical to minimize void space. ${ }^{6.10}$ More than one waste stream may be packaged in a disposal container, except those waste streams that shall be profiled separately (MW, Classified Waste, ALLW, etc.). $7.5 / 7.6 / 8.0$ MW packages shall meet the void space criteria in Section 3.3.6.2. ${ }^{8.0}$

\subsubsection{Package Protection}

Methods shall be employed to ensure that the integrity of the in-process waste package is not compromised (i.e., prohibited items are not introduced into the waste package). ${ }^{7.5}$

Once waste packaging activities have been completed and the container has been sealed, they shall be stored in a secure area to prevent unauthorized intrusion and protected from the environment to maintain package integrity and prevent deterioration. ${ }^{7.5}$ Storage should include protection from adverse weather, particularly rain and/or snow. Tamper-indicating devices (TIDs), clips, or

banding can be used to indicate that the package has not been opened. These devices shall not contain lead. ${ }^{7.5}$

\subsubsection{Marking and Labeling}

Each waste package shall be marked and labeled according to Appendix C. ${ }^{7.6}$ Markings and labels shall be intact and readable when the shipment arrives at the disposal site. $^{7.6}$

\subsubsection{Bar Coding}

The shipment and package numbers shall be bar coded according to the standards in Appendix C. ${ }^{7.6}$

\subsubsection{Contamination Levels}

External contamination levels for waste packages and transport vehicles shall meet the release limits specified in Title 10 CFR Part 835, Appendix D. ${ }^{7.13 / 1.6}$ When internal contamination levels (i.e. internal contamination of a Type B cask for waste removal and return to the generator) are known, this information shall be forwarded to RWMC operations (fax (702) 295-6852 or e-mail to wminfo@nv.doe.gov).

\subsubsection{Waste Containers and Shipping Configuration}

Generators shall ensure the following requirements are satisfied to improve transportation safety and off loading at the NNSS: $:^{7.5}$

- Waste containers used for shipping, at a minimum, will be Industrial Package 
- 1 (IP-1) meeting the requirements of 49 CFR 173.410 and 173.411.

- Waste packaged in drums will be palletized and banded. Pallet design should ensure they will support container weights without failure during handling and shipping. Banding should securely hold the drums to the pallet. Typical banding configurations would include two vertical and two horizontal bands around the drums. Drum palletizing and banding requirements do not apply to drums in groups of three drums or less.

- Wastes packaged in drums from off-site facilities are to be shipped in a closed transport vehicle.

- Waste containers not meeting the minimum requirements described above and/or alternative methods for transport of bulk waste items (SCO, LSA equipment, large machinery, etc.) will be approved on a case-by-case basis by the Waste Management Federal Project Director.

\subsection{Mixed Waste}

MW offered for disposal shall meet the applicable characterization, treatment, packaging, and disposal requirements of the NNSSWAC, Title 40 CFR, state of Nevada, and state-of-generation regulations. ${ }^{8.0}$

\subsubsection{Acceptable Hazardous Waste Numbers}

MW accepted for disposal shall have one or more of the EPA hazardous waste numbers listed below or shall be considered a hazardous waste in the state of generation: ${ }^{8.0}$

\section{Waste Codes}

D004 through D043 U364

F001 through F009, F039 U367

P001 through P205 U373

U001 through U249 U387

U271 U389

U278 U394

U279 U395

U280 U404

U327 U409

U328 U410

U353 U411

U359 


\subsubsection{Mixed Waste Treatment Notification}

Generators with MW that requires treatment to meet the LDR standards, but the treatment has yet to occur, shall submit to NNSA/NSO the information contained in the Pre-Treatment Notification Form found in Appendix G. ${ }^{8.0}$ This will allow the scheduling of on-site verification activities in accordance with Section 3.3.8. If treatment is performed by a commercial facility, it shall have a current DOE Consolidated Audit Program (DOECAP) audit, or equivalent. ${ }^{8.0}$

\subsubsection{Mixed Waste Profiles}

In addition to the NNSSWAC requirements for waste profiles in Section 2.1.1, MWPs shall be profiled and packaged separately from LLW. MWPs shall be approved for a finite volume of waste. ${ }^{8.0}$ MWPs shall include the number of containers, container sizes, and dose rates at $30 \mathrm{~cm}$ for the mixed waste covered by the MWP. ${ }^{8.0}$

MWPs have annual expiration dates and shall be recertified annually (based upon the profile revision date) to NNSA/NSO with the information contained in Appendix G-2. ${ }^{8.0}$

\subsubsection{Land Disposal Restrictions}

MW shall meet the LDR treatment standard requirements in Nevada Administrative Code (NAC) 444.8632 (incorporating Title 40 CFR 268.40 and 268.45), including standards for underlying hazardous constituents (UHCs). Waste meeting the alternative LDR treatment standard for contaminated soil, as defined by NAC 444.8632 (incorporating Title 40 CFR 268.49), is also accepted.

LDR notification /certification shall be made in accordance with Section 6.3.4. $3.11 / 8.0$

\subsubsection{Determinations of Equivalent Technology}

MWs that have been treated based on a Determination of Equivalent Technology (DET) will require NDEP concurrence on the DET. NDEP will require the DET documentation, including EPA regions' determinations. Any documentation of state-of-generation involvement in the DET should also be submitted. ${ }^{8.0}$

\subsubsection{Waste Form Criteria / Prohibited Items}

MW accepted for disposal shall meet the general waste form criteria as described in Section 3.1 except as indicated below. ${ }^{8.0}$ 


\subsubsection{Free Liquids}

Free liquids shall be absorbed, stabilized, or otherwise removed from the waste. Containerized free liquids such as ampules, small articles that contain free liquids required for the article to function (e.g., batteries or capacitors), are acceptable. ${ }^{3.9}$

\subsubsection{Sorbents}

Sorbents shall be nonbiodegradable and identified on the MWP. ${ }^{3.9}$ Examples of nonbiodegradable sorbents according to Title $40 \mathrm{CFR}$ 264.314(d) and/or 40 CFR 265.314(e) includes:

- Inorganic minerals, other inorganic materials and elemental carbon (e.g., aluminosilicates, clays, smectites, fuller's earth, bentonite, calcium bentonite, montmorillonite, calcined montmorillonite, kaolinite, micasillite, vermiculites, zeolites; calcium carbonate [organic free limestone], oxides/hydroxides, alumina, lime, silica sand, diatomaceous earth; perlite [volcanic glass], expanded volcanic rock; volcanic ash; cement kiln dust; fly ash; rice hull ash, activated charcoal/activated carbon).

- High molecular weight synthetic polymers (e.g., polyethylene, polypropylene, polyurethane). This does not include polymers derived from biological material or polymers specifically designed to be degradable.

- Sorbents determined to be nonbiodegradable under: American Society for Testing and Materials (ASTM) Method G21-70, Standard Practice for Determining Resistance of Synthetic Polymer Materials to Fungi; ASTM Method G22-76, Standard Practice for Determining Resistance of Plastics to Bacteria; or OWCS test 301B, CO2 Evolution.

\subsubsection{Compatibility}

Incompatible wastes, or incompatible wastes and materials shall not be placed in the same container if such placement: ${ }^{3.8}$

- Generates extreme heat or pressure, fire or explosion, or violent reaction;

- Produces uncontrolled toxic mists, fumes, dusts, or gases in sufficient quantities to threaten human health; 
- Produces uncontrolled flammable fumes or gases in sufficient quantities to pose a risk of fire or explosions;

- Damages the structural integrity of the device or facility containing the waste; or

- Through other like means threatens human health or the environment.

\subsubsection{MW Package Criteria}

In addition to Section 3.2, MW packaged for disposal shall meet the following waste package criteria:

\subsubsection{Marking and Labeling}

In addition to the marking and labeling requirements in Appendix $\mathrm{C}$, MW packages of 451 liters (119 gallons) or less shall be marked with the following: ${ }^{3.5}$

- The words "HAZARDOUS WASTE - Federal law prohibits improper disposal. If found, contact the nearest police or public safety authority of the U.S. Environmental Protection Agency;"

- Generator's name and address

- Manifest Document Number.

The marking shall be durable, in English, displayed on a background of sharply contrasting color, printed or affixed to the surface of the package; or on a label, tag, or sign un-obscured by other labels or attachments, located away from any marking that could substantially reduce its effectiveness. ${ }^{3.5}$

Marking and labeling of the waste packages shall be for the hazardous and radioactive characteristics of the waste. ${ }^{4.3 / 7.6}$

\subsubsection{Void Space}

Containers of MW shall be at least 90 percent full when placed in the landfill. ${ }^{3.10}$ Additional information on the mixed waste void space criteria can be found at the following web address:

http://www.nv.doe.gov/emprograms/environment/wastemanagement/rw ap.aspx 


\subsubsection{Package Protection}

In addition to the requirements of Section 3.2.10, if a package has been inspected as part of the NNSS verification plan, the TID shall not be removed or altered. The package shall be loaded and transported to protect the TID from damage.

\subsubsection{Analytical Data}

Analytical data used to make MW determinations or LDR certifications shall be from a DOECAP audited laboratory, or equivalent (i.e., State Certified or Carlsbad Field Office Certified). ${ }^{8.0}$ Generators shall document their review and acceptance of the most recent certification audit for analytical laboratory used. ${ }^{7.5}$

\subsubsection{MW Verification}

Verification frequencies and methods for MWPs are determined by the WARP in accordance with RWAP procedures. The methods include split sampling, field chemical screening, visual inspection and/or Real-Time Radiography (RTR) at the generator or treatment facility and RTR at the NNSS. Verifications are conducted in accordance with RWAP procedures. ${ }^{8.1}$

\subsubsection{MW Verification Frequency}

MW verification frequencies are assigned by the WARP. Per the MWP a minimum of 5 percent of waste containers shall be physically screened by either visual inspection or RTR. ${ }^{8.0}$

Exceptions to the physical screening requirements shall be approved by the NNSA/NSO RWAP Manager. ${ }^{8.0}$

Unless exempted, a minimum of 10 percent of containers physically screened shall be chemically screened. ${ }^{8.0}$ The following wastes are exempted from chemical screening: ${ }^{8.0}$

- Waste subjected to an LDR-specified technology standard

- Hazardous debris

- Chemical-containing equipment removed from service (ballasts, batteries, etc.)

- MW containing regulated asbestos

- Waste from the cleanup of spills or a release of a single substance or known material (e.g., material for which a Material Safety Data Sheet [MSDS] can be provided) 
- Confirmed noninfectious waste generated from laboratory tissue preparation, slide staining, or fixing processes

- Waste containing beryllium

Chemical screening of waste container contents are performed by RWAP personnel at the generator's site. If a container is too large to RTR at NNSS, the waste will be visually verified at the generator's site. ${ }^{80}$

Generators shall provide the necessary authorizations, facilities, and personnel to allow RWAP personnel to perform MW verification at the generator or treatment facility.

RWAP personnel shall be provided access to containers and facilities to allow for visual inspection of the contents of packaged containers, performing chemical screening on homogeneous samples of the waste, and split sampling

\subsubsection{Previously Rejected MW Packages}

MW packages (parent packages) previously rejected that are repackaged and/or split into additional MW packages (progeny packages), shall be traceable to the original package number. ${ }^{8.0}$

In addition, to transportation and shipping requirements of Section 6.0, generators shall notify NNSA/NSO prior to shipping previously rejected MW packages (parent and/or progeny) back to NNSS. ${ }^{7.5}$

\subsection{NNSSWAC Deviations}

Deviations from the NNSSWAC that do not compromise the performance objectives for the disposal site, NNSS Documented Safety Analysis requirements and limitations, or violate permit requirements are evaluated on a case-by-case basis for acceptance. Deviations are not used as an all-inclusive relief from meeting a specified NNSSWAC requirement.

The following information shall be provided with the WP or as a stand-alone document approved by the WCO: NNSSWAC requirement(s) that cannot be satisfied; justification for not meeting the requirement that includes a description of the item(s) and/or process affected; duration of the deviation; and planned action(s) to correct the deviation, if applicable. ${ }^{6.15 / 7.5}$ 


\section{Example:}

Requirement: NNSSWAC, Revision 7-01, Section 3.2.5, Strength, requires that disposal packages shall be capable of supporting a uniformly distributed load of $16,477 \mathrm{~kg} / \mathrm{m}^{2}\left(3,375 \mathrm{lbs} / \mathrm{ft}^{2}\right)$.

Justification: Two 4 x 4 x 7ft metal boxes (\#33248 and \# 33798) do not meet the NNSSWAC strength requirement. Because of ALARA concerns, the generator seeks to avoid unnecessary exposure to personnel. The boxes will be clearly marked "Box Does Not Meet NNSSWAC Strength Requirement," at a minimum, on the top and one side.

Duration: One time only for box numbers 33248 and 33798.

Corrective Action: None required, it is the intent of the generator to ensure that only compliant containers will be used on future shipments. 



\subsection{Waste Characterization}

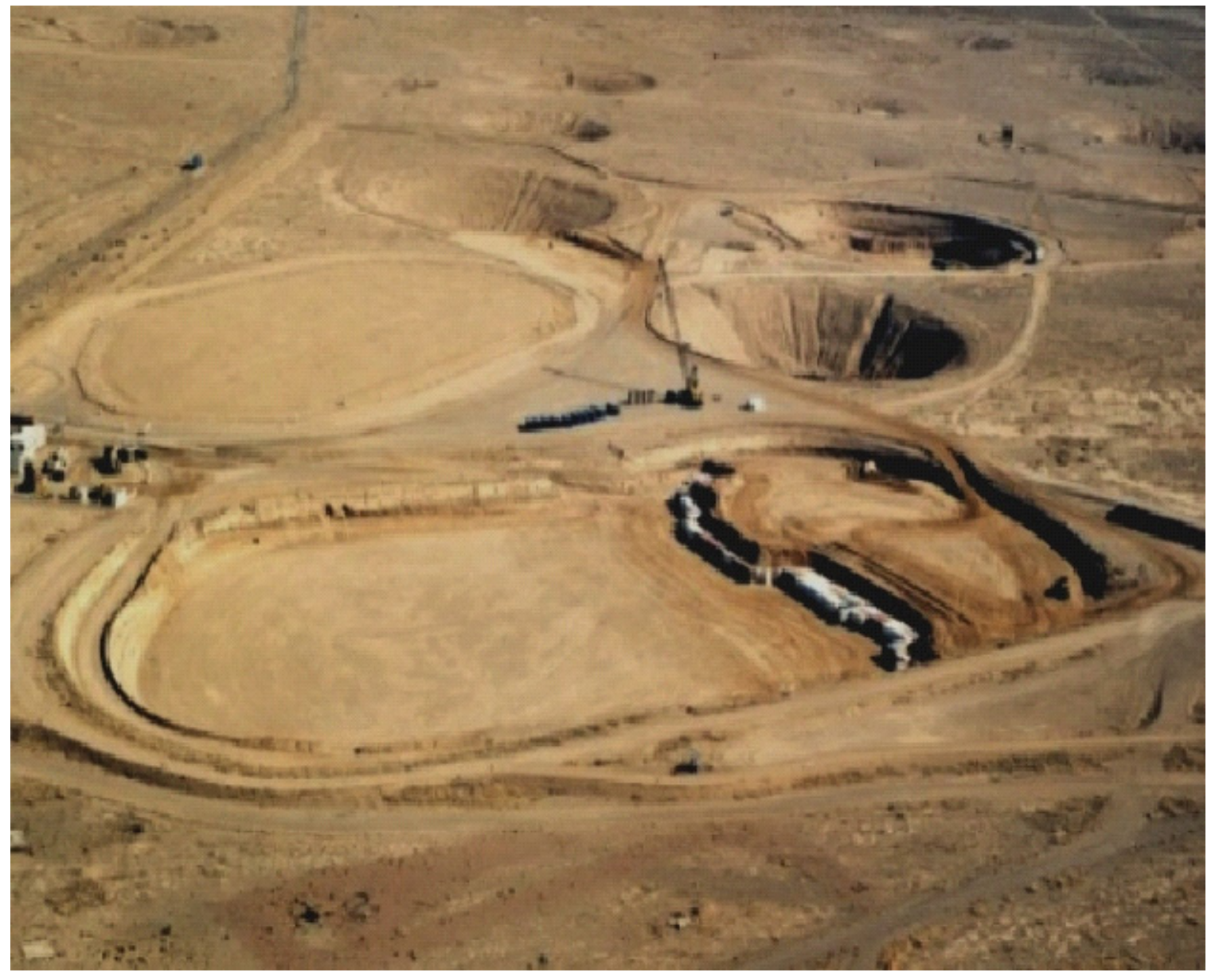

Area 3 Radioactive Waste Management Complex, Nevada National Security Site 
This page intentionally left blank. 


\subsection{Waste Characterization}

Generators shall characterize waste destined for disposal at NNSS. ${ }^{6.16}$ When similar requirements are listed in separate regulations, the most stringent shall be met. ${ }^{7.5}$ Waste will not be accepted until the generator, through sampling and analysis, process knowledge (PK), or a combination of both, demonstrates the waste to be LLW that meets the NNSSWAC requirements in Section 3.0. For waste characterized as MW, generators shall demonstrate that the MW meets the applicable Title 40 CFR LDR and WAC. ${ }^{3.10}$ Generators shall characterize waste with sufficient accuracy to permit proper segregation, treatment, storage, and disposal. ${ }^{6.16}$ The characterization methods and procedures employed by the generator shall ensure that the physical, chemical, and radiological characteristics of the waste are recorded and known during all stages of the waste management process. ${ }^{6.16}$ Methods selected by the generator for waste characterization shall undergo a documented peer review. ${ }^{7.5}$ The Data Quality Objective (DQO [s]) process, or a comparable process, shall be used for identifying characterization parameters and acceptable uncertainty in characterization data. ${ }^{6.17}$

Generators shall prepare and submit a WP for each waste stream that provides NNSA/NSO with a summary of waste characterization information. ${ }^{6.716 .22 / 7.5}$ Generators shall provide waste characterization documentation that supports the WP (see Appendix E for radiological requirements) to NNSA/NSO for review during facility evaluations or upon NNSA/NSO request. ${ }^{6.16 / 7.5}$

Waste characterization documentation shall be traceable to the WP and disposal packages. ${ }^{7.5}$ Isotopic distributions and corresponding activity concentrations shall be traceable to the package. ${ }^{7.5}$ Traceability to a parcel level shall be required if characterization is being conducted at that level (e.g., individual sealed sources, bags, or components characterized on an individual basis, but packaged together). ${ }^{7.5}$ Waste characterization may be conducted using PK, sampling and analysis, or a combination of both. The following sections provide specific information and requirements for these characterization methods.

\subsection{Process Knowledge}

PK is a characterization technique that relies on the generator's knowledge of the physical, chemical, and radiological properties of the materials associated with the waste generation processes. It includes knowledge of the fate of those materials during and subsequent to the process, and the associated administrative controls. PK sources include, but are not limited to, the following programmatic and waste stream-specific components:

- Plans and drawings

- Areas and/or buildings where each waste stream is generated

- Material inputs, including MSDSs

- Manufacturing specifications 
- Mass balance documentation

- Literature searches

- Living memory (documented interviews)

- Laboratory notes and batch records

- Process logs and batch records

- Procedures

Historical data should be routinely verified through controlled analytical methods such as verification sampling and analysis; however, if the data can successfully undergo a full validation, this verification may not be necessary.

When PK relies on living memory, the individual's knowledge shall be documented and signed by both the interviewer and the interviewee. ${ }^{7.5}$ For telephone interviews, a statement outlining relevant information shall be signed by the interviewer (and interviewee, if possible). ${ }^{7.5}$

PK can be used for waste characterization in lieu of sampling and analysis if the generator's PK is of sufficient detail to qualify as acceptable. Acceptable PK is based on detailed information on the waste obtained from existing waste analysis data, studies on similar waste generating process(es), or detailed information relative to the properties of the waste that are known due to site-specific and/or process-specific factors.

Generators shall conduct a documented evaluation of compiled PK sources used for waste characterization. ${ }^{7.10}$ The generator's evaluation shall identify uncertainties, inconsistencies, limitations, and usefulness. ${ }^{7.10}$

\subsection{Sampling and Analysis}

Generators shall ensure that all data be scientifically valid, defensible, and of known precision and accuracy to identify the physical, chemical, and radiological properties of the waste. ${ }^{7.7}$ When waste streams are characterized by sampling and analysis, the process shall be controlled and documented. ${ }^{6.24 / 1.3}$ Propagation of error throughout the sampling and analytical process shall be evaluated and considered when ascertaining usability of data for characterization of waste. ${ }^{6.16}$ Generators should determine the appropriate analysis (total vs. TCLP) for RCRA hazardous and UHC determinations. The results shall be reported in the waste profile on Table B-1 (page 4-5). ${ }^{7.5}$ Refer to the waste profile instructions for further details on reporting sampling results.

Generators shall demonstrate that controls are in place to trace each sample number to a specific package number. ${ }^{7.5}$ NNSA/NSO may evaluate sampling and analysis documentation to ensure that: 1) samples will be representative of the waste inventory, 2) appropriate analytical procedures are used, and 3) sufficient quality controls have been established to allow measurement and documentation of data quality. 


\subsubsection{Data Validation}

Data validation is a comprehensive analysis and review of analytical data conducted against a set of predetermined criteria and leading to the assignment of relative usability (i.e., completely usable, estimated value, unusable) for each analytical result. The validation criteria should be developed using the DQO process and depend upon the type(s) of data involved and the purpose for which the data are collected. Data shall be validated by technically qualified personnel who are independent of those performing the analyses. ${ }^{7.5}$

When sampling and analysis is used as a method of characterization, data validation shall be conducted on a portion of chemical and radiological data prior to use of the data for characterization. ${ }^{7.5}$

The WP instructions require completion of an analytical results summary (Table B-1) for inclusion in the WP. As required by the above paragraph, data validation will be performed on a portion of the data used to complete the table. If in subsequent sampling events, variations of analytical results remain less than 80 percent of the applicable regulatory threshold, revision of Table B-1 is not required. If the results ever exceed 80 percent of the regulatory threshold, it will be necessary to revise the table and submit appropriate validation summary reports (case narratives) for the values entered in the revised table.

Validation summary reports should cite the guidelines or procedures used to validate the data and include, at a minimum:

- Method/Analysis-general discussion of the data set, including preparation/dilutions, initial and continuing calibration, holding times.

- Method blank Analysis

- LCS Analysis

- Surrogate Spike Recoveries

- Data Qualifier Codes

- Discussion/Statement of data quality 
Table B-1: Analytical Results

Table B-1

Analytical Results

TCLP Metals:

Arsenic

Barium

Cadmium

Chromium

Lead

Mercury

Selenium

Silver

TCLP Volatiles

Benzene

Carbon

Tetrachloride

Chlorobenzene

Chloroform

1,4-

Dichlorobenzene

1,2-Dichloroethane

Methyl ethyl ketone

Pyridine

\section{TCLP Volatiles}

Tetrachloroethylene

Trichloroethylene

Vinyl chloride

Dichloroethylene
Upper

Statistical

Mean

Confidence

Limit
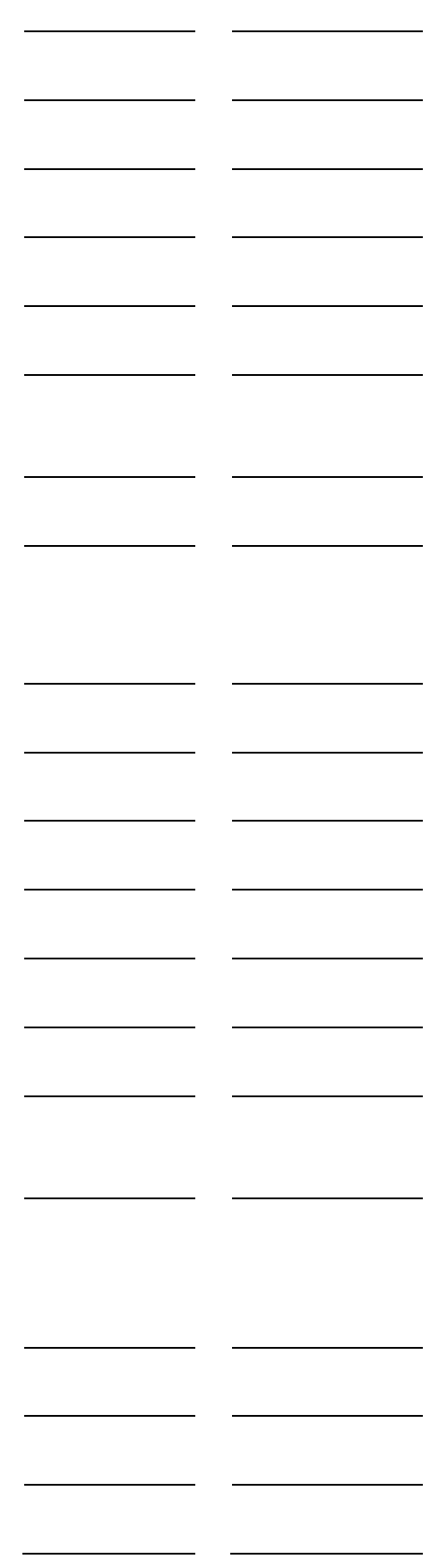

Statistical

Mean

Upper

Confidence

Limit

\section{TCLP Semivolatiles:}

o-Cresol

p-Cresol

m-Cresol

Cresol

Dinitrotoluene

Hexachlorobenzene

Hexachloro-1,3-

butadiene

Nitrobenzene

Pentachlorophenol

2,4,5-

Trichlorophenol

2,4,6-

Trichlorophenol

Hexachloroethane

\section{TCLP Pesticides and Herbicides:}

Chlordane

2,4-D

Endrin

Heptachlor and

Hydroxide

\section{TCLP Pesticides and Herbicides:}

Lindane

Methoxychlor

Toxaphene

2,4,5-TP (Silvex) 


\subsection{Quality Assurance Requirements for}

\section{Waste Certification Programs}

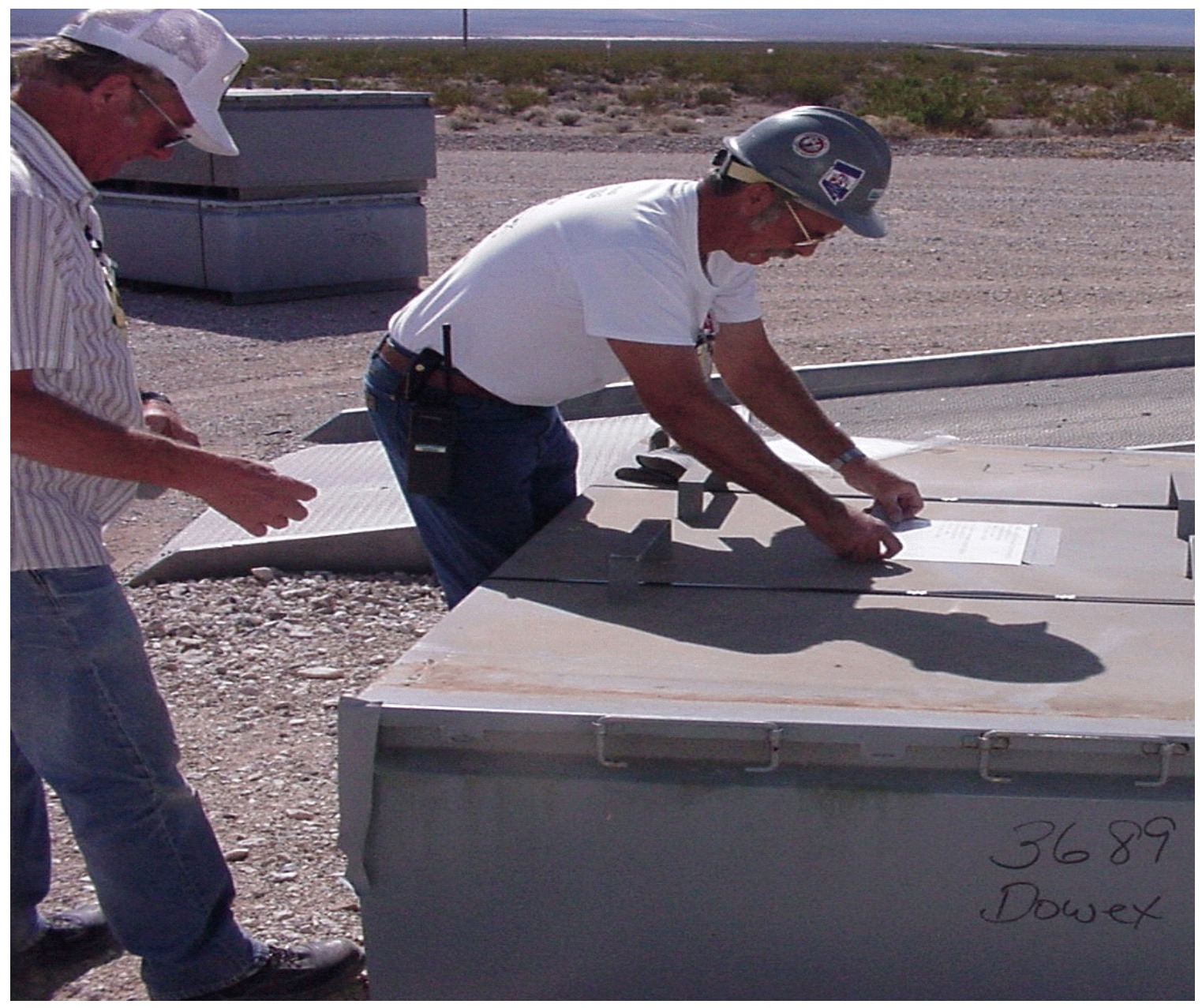

Area 5 RWMC Workers Labeling Boxes, Nevada National Security Site 
This page intentionally left blank. 


\subsection{Quality Assurance Requirements for Waste Certification Programs}

RWAP quality requirements are written in accordance with DOE Order 414.1, "Quality Assurance"; Title 10 CFR 830.122, "Quality Assurance"; and NNSA/NSO Policy unless otherwise noted by superscript.

Generators shall develop, approve and maintain a Quality Assurance Program Plan (QAPP) demonstrating compliance to the current revision of the NNSSWAC, DOE Order 435.1, "Radioactive Waste Management," DOE Order 414.1, "Quality Assurance," and/or Title 10 CFR, 830.122, “Quality Assurance." In lieu of using a site QAPP, an NNSSWAC specific Waste Certification Program Plan (WCPP) may be submitted as the site implementing program document. A controlled copy of the generators site QAPP or WCPP shall be maintained with the RWAP Manager.

Generators shall also complete the NNSSWAC Implementation Crosswalk (NIC) and submit it to the RWAP Manager. The NIC shall reference the applicable quality-affecting procedures, processes, or methods and the organization/group directly responsible for implementation.

Procedures, processes, or methods referenced should include:

- Implementing plans, procedures, documents, and/or records that demonstrate how implementation of applicable NNSSWAC requirements is performed, including support organizations.

- Waste characterization data, methods, and records demonstrating compliance.

- Documents demonstrating compliance to waste and packaging criteria in Section 3.0 of the NNSSWAC.

- Documents assuring conformance to marking, labeling, electronic reporting, and form submittal requirements.

The WCO shall perform an annual review of the NIC to ensure referenced procedures, processes, and methods are current. Upon completion of the annual review, the WCO shall sign the NIC cover sheet and submit a copy to the RWAP Manager. An electronic copy of the NIC and instructions are available on the NNSA/NSO web site (see Section 2.2.1).

\subsection{Program}

Generators shall develop an organizational chart specific to the waste management and support organizations. The organizational chart shall depict the organizational structure, functional responsibilities, levels of authority, and interfaces necessary to manage the waste certification program. The chart shall identify the organizations that generate, characterize, package, inspect, assess, ship, and perform support functions (i.e., procurement, document control, RCRA oversight, and training). 
Each generator shall designate a WCO and alternate(s), if applicable, who are responsible for verifying implementation of the QAPP or WCPP. The WCO shall ensure that the waste certification processes, including waste, waste packages, supporting data, and waste shipments, comply with the requirements of the NNSSWAC. The alternate WCO shall report to the primary WCO for certification activities. The organizational structure shall ensure the independence of the WCO, alternates(s), and package certifiers from the waste generator and allow for direct access to a management level (including the local DOE field office), having sufficient authority and organizational freedom, if necessary, to ensure compliance with the LLW program.

Generators may delegate responsibility for signing the Package Certification Label (PCL) to Package Certifiers; however, the Package Certifiers shall report directly to the $\mathrm{WCO}$ when performing waste certification activities.

\subsection{Personnel Training and Qualification}

Personnel shall be trained and qualified to perform their assigned functions and tasks. The level and type of training shall be evaluated and documented. Training shall be commensurate with the importance of the task and the activities affecting compliance with the NNSSWAC waste certification activities. Personnel shall be provided training to ensure that job proficiency with established requirements (e.g., processes, procedures, and instructions) is maintained. Records of training shall be specified and maintained to ensure personnel training are current.

\subsection{Quality Improvement}

Process controls to detect and prevent quality problems and verify conformance to specified requirements shall be established and implemented. Performance of quality improvement processes shall be documented.

Control of nonconforming components and processes shall provide for the identification, documentation, evaluation, segregation (when practical), disposition, and notification to the affected organizations, including the WCO. Nonconforming components shall be conspicuously labeled, tagged, or otherwise marked to ensure removal from the waste certification process and prevent inadvertent use.

The disposition of nonconforming components, services, and processes shall be reviewed for technical justification and disposition by authorized personnel. When nonconforming conditions are identified that affect the quality of previously shipped waste, NNSA/NSO shall be notified.

A process shall be established for the identification and timely correction of quality problems. The root cause, corrective action, action to prevent recurrence, and estimated completion date shall be documented. The WCO and appropriate levels of management shall be involved in the corrective action process. Corrective action documents shall be tracked until successful resolution can be demonstrated. 


\subsection{Documents and Records}

Activities affecting the quality of the waste certification program shall be prescribed and performed in accordance with written instructions, procedures, or drawings, and available to those performing the work. A document control system shall be established to assure that these documents are prepared, reviewed, approved, controlled, and revised.

The WCO shall document the review and concurrence of procedures (including revisions) critical to waste certification activities (generation, packaging, inspection, characterization, certification, etc.).

The records system shall be defined and implemented in accordance with written instructions, procedures, or other documentation.

Records documenting compliance with waste certification criteria shall be specified, prepared, reviewed, and signed by authorized personnel.

Records shall be compiled into a records management system that includes provisions for transmittal, distribution, retention, handling, correction, disposition, and retrievability. Completed records shall be protected from damage, loss, and deterioration.

The generator shall maintain records for periods designated by other regulatory authorities).

\subsection{Work Processes}

Work shall be planned and performed to established technical standards and administrative controls using approved instructions, procedures, or other appropriate means.

Processes important to waste certification activities shall have controls or verification steps identified as part of the operating procedures.

Controls shall be established to ensure that the traceability of waste from the point of generation through shipment is maintained. Waste characterization documentation shall be traceable to the exact package in which waste was placed. Waste containers shall be controlled through the life cycle of the component (e.g., receipt, handling, storage, packaging, and shipping) to prevent damage, loss, or deterioration.

Components used in the certification process such as waste containers, liners, sorbents, and solidifiers shall be controlled to ensure that only correct and acceptable items are used. Identification shall be maintained on items or documents traceable to the items. 
Measuring and Test Equipment (M\&TE) used for process monitoring or data collection shall be uniquely identified, controlled, and calibrated. Records of calibration shall be maintained, traceable to the equipment, and the equipment suitably marked to indicate calibration status. The M\&TE marking shall include a unique identification, date of calibration, calibration due date, and any limitations. Calibration equipment for M\&TE shall be traceable to a nationally recognized standard or equivalent means to assure accuracy.

Testing and validation of computer programs and verification of data results from those programs (i.e., PSDR data, radioactivity calculations) shall be conducted and documented.

\subsection{Design}

Structures, Systems, and Components (SSCs) designed and/or constructed to ensure that waste will satisfy certification requirements shall be designed using sound engineering/scientific principles and standards and performed in accordance with established design processes.

Design adequacy of SSCs shall be verified or validated by qualified personnel other than those who initiated the design. Verification and validation of SSC designs shall be completed and approved prior to implementation of the design or design changes.

Design interfaces shall be identified and controlled. Waste generators shall document their review of product or process designs (e.g., waste containers, sorbents, waste treatment operations) when performed by others (e.g., suppliers or other generators) to ensure that they conform to established requirements and end-use application.

Design changes shall be approved commensurate with the same control measures that were applied to the original design.

\subsection{Procurement}

Components and services critical to the waste certification program shall be procured under a controlled and documented system. Procurement documents shall identify applicable technical requirements such as drawings, specifications, codes, standards, regulations, tests, inspection and acceptance criteria, and certification records.

Procurement documents shall be reviewed and approved by authorized personnel to ensure that they contain appropriate references and technical requirements. Changes to procurement documents shall receive the same degree of review and approval as the original documents.

Selection of suppliers providing components and services critical to the waste certification program shall be evaluated and selected based on specified criteria (e.g., waste packaging, waste treatment services). The methods of evaluation (i.e., audits, surveillance, source inspection, receipt inspection, third party audits) shall be established and provide adequate confidence that the selected supplier can meet the 
established requirements. When third-party audits are used to qualify a supplier, a documented evaluation of the report shall be performed by a qualified Lead Auditor identifying the activities, findings, conclusions, and basis for qualification.

Suppliers of components (e.g., off-the-shelf sorbents) that are tested or verified by the purchasing organization for conformance to technical requirements may not need to be evaluated (audited), provided the testing demonstrates the procured component conforms to design requirements. Conformance testing shall be documented.

A process to ensure approved suppliers continue to provide acceptable components and/or services shall be established and implemented. Methods of evaluation shall be specified and documented.

\subsection{Inspection and Acceptance Testing}

Inspection and testing of components, services, and processes critical to the waste certification program shall be conducted using established acceptance and performance criteria. In-process inspections of waste certification activities shall be performed by qualified personnel having no responsibility for the work process or item being inspected.

Receipt inspections shall be performed to verify conformance of components received to the procurement documents and design criteria.

In-process inspections, including waste container pre-use inspections and waste packaging activities, shall be conducted throughout the waste certification process. Final inspections shall be conducted to verify conformance of the waste, containers, and waste certification process to the NNSSWAC prior to shipment of the waste.

Records of inspection shall identify the type of inspection, component(s), services, or process inspected, date of inspection, inspector, inspection results, and action taken if nonconforming conditions are identified.

\subsection{Management Assessment}

Management of Waste Certification Program elements described in this document (Sections 3.0-6.0), shall periodically assess their processes to ensure conditions that preclude their organization from achieving objectives are identified and corrected. Management assessment programs/processes shall ensure results of management assessments are documented in a final report issued to the appropriate organization(s) and the WCO for review.

\subsection{Independent Assessment}

Assessment activities (audits and surveillances) shall be planned, scheduled, and conducted in accordance with a documented and approved process. Assessment personnel shall be independent of the assessed areas and have sufficient authority and freedom to perform assessment activities. 
Waste certification programs shall be independently assessed annually to verify compliance with NNSSWAC program requirements to promote process improvement.

Surveillances may be accumulated and used in lieu of a formal annual assessment provided they were conducted within 12 months of the last annual assessment and encompass the entire waste certification program and supporting elements. When surveillances are used as the annual assessment, a final report shall be prepared identifying the assessed program elements/activities, conclusions, findings, and corrective actions initiated to resolve them and their status.

Annual independent assessments and/or surveillance roll-up shall be performed and documented by a qualified Lead Auditor. An approved copy of the annual independent assessment report, including any findings issued, shall be forwarded to the RWAP Manager.

The WCO and/or supporting oversight organizations shall schedule and conduct periodic surveillances of specific activities critical to the waste certification program (personnel training, waste packaging, receipt inspection, control of M\&TE, etc.). Personnel performing surveillances shall be qualified in the surveillance process and knowledgeable of the areas being assessed.

Results of assessment activities (audits and surveillances) shall be documented, approved, and reported to responsible management, including the WCO.

Deficiencies identified during assessment activities shall be tracked until acceptable resolution is achieved and verified. 


\subsection{Waste Transportation and Receipt Information}

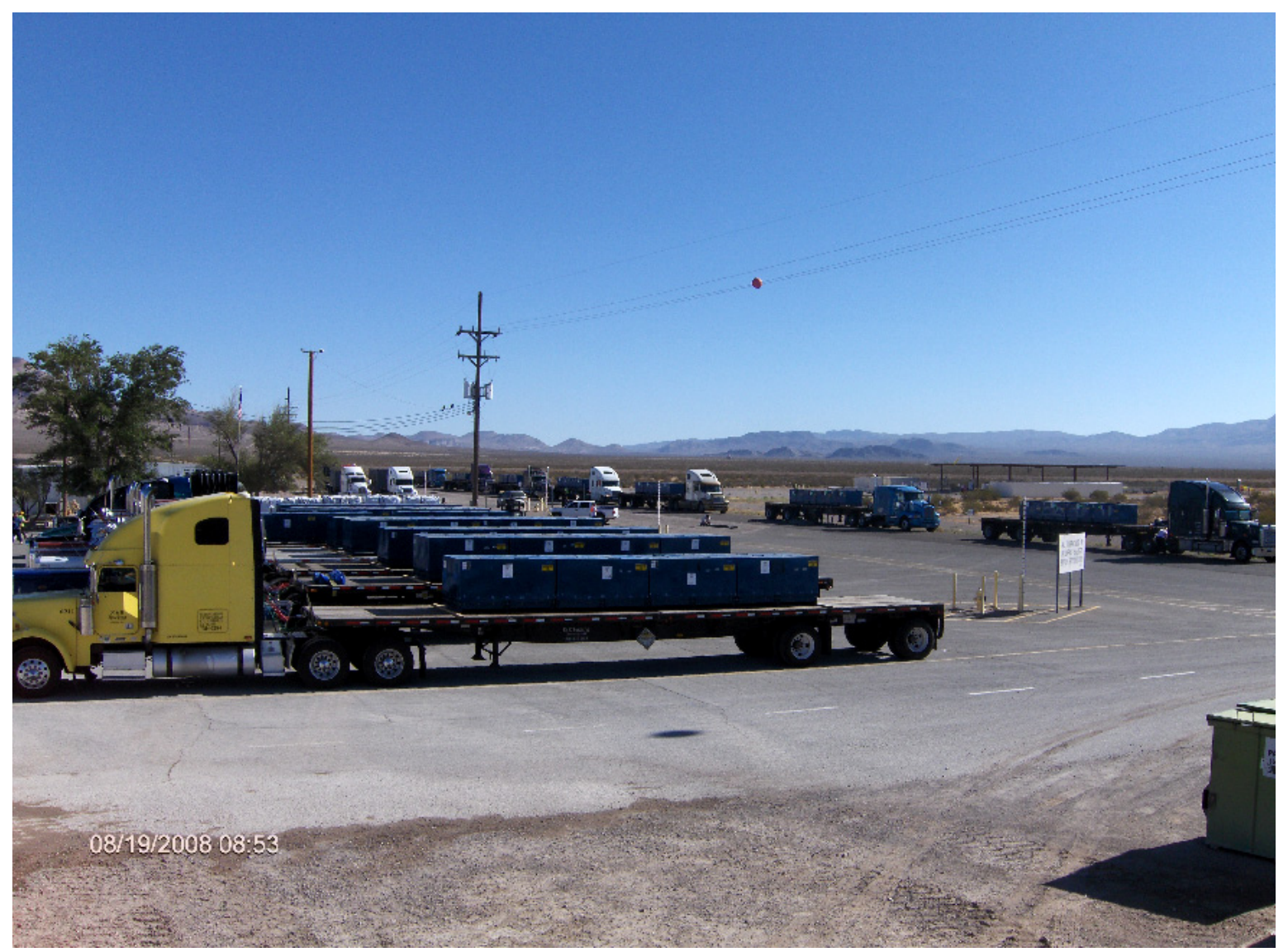

Receiving waste in the Area 5 Radioactive Waste Management Complex, Nevada National Security Site 
This page intentionally left blank. 


\subsection{Waste Transportation and Receipt}

This section provides general guidelines that generators follow to expedite waste transportation and receipt.

\subsection{Shipment Scheduling and Limitations}

RWMC Operations may impose schedule limitations on waste profiles that have specific handling and/or processing requirements. Classified Waste, ALLW, and MW shipments may have a shipment frequency limitation to accommodate additional processing needs. (For example, classified shipments may be limited to four shipments per day per generator, with a generator limited to Tuesday and Thursday arrivals.) All scheduling limitations shall be made through RWMC Operations. ${ }^{7.6}$ Containers that are to be returned to the generator (intermodal containers, shipping casks, etc.) may have shipment scheduling limitations (e.g., due to weather conditions) and the schedule may be modified and/or suspended as warranted.

RWMC operations may occasionally extend operating hours (i.e., Fridays). During these extra periods, RWMC operations will designate the type of shipments that will be received on the given date (e.g., on the third Friday in September, the NNSS will accept cargo containers of standard LLW and DOT non-regulated bulk).

\subsection{Shipping Arrangements}

After a generator secures written approval from the NNSA/NSO WMP Federal Project Director to ship waste to the NNSS RWMC, the generator shall contact RWMC operations to arrange for transfer of approved waste streams and accompanying records. ${ }^{7.5}$ The operator of the RWMC coordinates waste shipment transfers at NNSS.

\subsubsection{Waste Receipt and Handling at NNSS}

To expedite waste receipt and handling at NNSS, waste generators shall, at a minimum, comply with the following: ${ }^{7.6}$

- Prior to departure of a waste shipment to the NNSS, attach security seals to the shipping trailer's door latches or to each package if not enclosed in a trailer. $^{7.6}$

- Instruct transport driver on the importance of fully completing the "Drivers Questionnaire," at the NNSS before leaving the RWMC.

- Enter the following pre-notification information on the HAZTRAK database. $^{7.6}$ If the generator is unable to enter information into HAZTRAK, 
the NNSS Advance Shipment Notification (see Appendix C.4) may be faxed (702) 295-6852 or emailed to wminfo@nv.doe.gov. Enter NNSS shipments in the HAZTRAK database prior to 1500 NNSS local time, at least one working day prior to shipment arrival (e.g., shipments scheduled to arrive Monday will be entered in HAZTRAK by 1500 NNSS local time on the previous Thursday). ${ }^{7.6}$ NNSS advance shipment notification being faxed to the NNSS shall be received prior to the cutoff time and date. ${ }^{7.6}$ For classified waste, having classified shipping documents, generators shall contact Wackenhut Services at (702) 295-7028. ${ }^{7.6}$ For all shipments, the following information shall be provided. ${ }^{7.6}$

- Date shipment departed generator site

- Estimated date of arrival (ETA) at NNSS

○ Shipment number, shipper's name, shipper's contact number

○ Carrier, driver's name (shall be a U.S. Citizen)

- Trailer number, seal number(s), DOT "Proper Shipping Name(s)"

- Number of packages, package type (boxes, drums, cargo containers, burrito wraps, etc.), and gross weight

If the shipment's ETA should change, the generator shall notify RWMC operations and shall enter the changes on the HAZTRAK database at the earliest opportunity and provide the new ETA. ${ }^{7.6}$ Generators unable to update information on the HAZTRAK shall notify the NNSS by phone at (702) 295$6811^{7.6}$

The majority of the above information can be found on the "Bill of Lading."

- For waste shipments containing regulated asbestos, the 7-day advance notification form shall be submitted to NNSA/NSO; see Section 3.1.15.

\subsubsection{Consignment of Shipments}

Consign waste shipments to:

National Security Technologies, LLC (NSTec)

For U.S. Department of Energy

Waste Management

Nevada National Security Site - Zone 2

Mercury, NV 89023

Because unclassified and classified shipments are processed differently, they shall be shipped separately (i.e., on different trailers and have different shipment numbers and separate shipping papers). ${ }^{7.6}$ This also applies to ALLW and MW (i.e., shipped separately from standard LLW). Under small-volume conditions, combined shipments can be arranged by contacting the operator of the NNSS. 


\subsubsection{Receiving Hours}

The hours for receiving waste at the RWMC are from 0700 to 1400 hours, Monday through Thursday, except holidays. Tractor-trailers arriving between 0700 and 1400 hours (Monday through Thursday) will be allowed to remain at the Area 3 or 5 RWMC until their delivery is complete. Shipments containing waste streams having tritium (H-3) should arrive at the Nevada National Security Site no later than 1200 hours to allow ample time for off loading, survey, and swipe analysis. If a shipment arrives between 1400 and 0700 hours, tractor-trailers will be required to exit the NNSS to return after 0700 hours for off-loading. Shipments may be subject to off-loading delays at any time due to NNSS operational schedules.

All shipments to Area 3 or Area 5 RWMC will be verified against a shipment tracking list by a Security Police Officer (SPO) at the NNSS main gate. If the shipment tracking number is listed, the shipment will be authorized to enter the NNSS. If the shipment is not listed, the SPO will attempt to contact an RWMC official to verify the shipment to authorize entry.

\subsection{Shipping Documentation}

The following records are required:

\subsubsection{Accountable or Special Nuclear Material Shipments}

For accountable or special nuclear material shipments, a "Nuclear Material Transaction Report" (DOE/U.S. Nuclear Regulatory Commission [NRC] Form 741) shall be completed for transfers of nuclear material between facilities having differing Reporting Identification Symbols. ${ }^{6.3 .1}$ The original Nuclear Material Transaction Reports shall accompany the shipment paperwork or submitted via email towminfo@nv.doe.gov prior to shipment arrival. ${ }^{7.5}$ Generators shipping waste that require a DOE/NRC Form 741 shall also complete and fax a "Nevada National Security Site - Waste RIS VAB Accountable Nuclear Materials Authorization to Ship Waste" form to (702) 295-4215 or e-mail (klamanda@nv.doe.gov or pricem@nv.doe.gov) seven (7) days prior to shipment.

Generators shall obtain authorization to ship from NNSS Material Control \& Accountability (MC\&A) prior to shipping the waste to the NNSS. ${ }^{7.5}$ An electronic copy of the "Nevada National Security Site - Waste RIS VAB Accountable Nuclear Materials Authorization to Ship Waste" form is available on the NNSA/NSO website at

http://www.nv.doe.gov/emprograms/environment/wastemanagement/rwap.aspx. 
Applicable shipment numbers shall be included on both the Nuclear Material Transaction Report (DOE/NRC Form 741) and on the Nevada National Security Site - Waste RIS VAB Accountable Nuclear Materials Authorization to Ship Waste form. ${ }^{7.5}$

For additional information, call the RWMC at (702) 295-6811. Contact Wackenhut Services at (702) 295-7028 if the shipping documentation contains classified information.

\subsubsection{DOT-Regulated Shipments}

For materials regulated by DOT, complete shipping papers with shipper's certification, as required by Title 49 CFR, shall accompany each shipment. ${ }^{4.1}$ A "Uniform Hazardous Waste Manifest" accompanied by the appropriate documentation shall be used when shipping MW. ${ }^{3.4 / .12}$

\subsubsection{PSDR Submittal}

The original completed and signed PSDR, or the original of an equivalent, shall accompany each shipment. ${ }^{6.20 / 7.6}$ An electronic version of the PSDR shall be transmitted to RWMC operations prior to shipment arrival (E-mail address: wmdata@nv.doe.gov). ${ }^{7.6}$ Shipments shall not be accepted if an electronic PSDR is not on file. ${ }^{7.6}$

\subsubsection{Additional Certification Statements}

An appropriate LLW Certification Statement shall be signed by an authorized WCO or Alternate WCO for LLW (see following example of the required LLW Certification). ${ }^{3.12 / 6.21 / 7.5}$

An appropriate LDR Certification Statement shall be signed by knowledgeable authorized individual, which may include the WCO or Alternate WCO for MW (see Title 40 CFR 268.7 for information required to be included in an LDR certification/notification). ${ }^{7.5}$

The LDR certification/notification is required for the initial shipment of the waste stream or when the waste profile/LDR information changes. 
I certify that containers:

Low-Level Waste Certification

Container I.D. number(s)

do not contain hazardous waste as defined in Title 40 CFR 261 or generation) hazardous waste regulations:

(state-of-

(1) According to the results of tests performed in accordance with the requirements as specified in Subpart C of Title 40 CFR 261, and/or

(2) According to the supporting documentation provided to me about the materials and processes that produced this waste.

To the best of my knowledge, I believe the information I have submitted is true, accurate, and complete.

Generator Waste Certification Official (print name / sign) Date

\subsection{Waste Transportation}

Waste shipments consigned to NNSS shall be made in accordance with applicable DOE, DOT, EPA, state, and local hazardous waste regulations and requirements. $^{7.5}$ Waste shipments to the NNSS shall be made by "exclusive-use vehicles" only. ${ }^{4.11}$ The sharing of conveyances with other DOE waste generators shipping directly to the NNSS is acceptable. Generators are responsible for the evaluation of the motor carriers used for transporting radioactive waste. Motor carrier documentation (e.g., past carrier performance, prior evaluations, accident history, vehicle maintenance) should be reviewed to ensure that the carrier complies with Title 49 CFR, state, and local transportation requirements. If carrier performance has been determined to violate federal, state, or local transportation safety regulations, a demonstration of corrective action may be required. Failure to initiate corrective action may result in waste refusal at the NNSS.

NNSA/NSO shall be notified when (1) the motor carrier(s) is being evaluated; (2) the motor carrier route selection is being reviewed; (3) a motor carrier discrepancy, noncompliance, or inadequate performance has been identified; or (4) there is a transportation incident or emergency situation. ${ }^{7.6}$ This notification will keep NNSA/NSO personnel informed of generator transportation plans, activities, and issues. NNSA/NSO personnel will use the information provided to 
inform stakeholders of transportation activities for radioactive LLW destined for the NNSS. NNSA/NSO personnel may request to participate in the review of transportation-related information. NNSA/NSO may provide driver advisories to inform generators of local driving conditions (e.g., road construction, detours, and safety issues). The generators will be responsible for providing carriers with driver advisories.

Generators shall ensure that a National Environmental Policy Act (NEPA) analysis (Title 10 CFR 1021) of the potential waste transportation impacts is completed prior to waste shipment. Transportation of waste to the NNSS should conform to a supporting finding or decision based on the impact analysis.

NNSA/NSO encourages approved generators and their carriers to review route selections. Radioactive waste transportation to the NNSS, regardless of DOT classification, shall avoid Hoover Dam and Las Vegas. ${ }^{7.5}$ Routes selected are required to minimize radiological risk. Information on accident rates, time in transit, population density, construction activities, and time of day shall be considered when determining radiological risk. ${ }^{4.9}$

\subsection{Waste Receipt and Records}

The operator of the $\mathrm{S}$ will be responsible for inspecting radioactive waste shipments upon arrival and maintaining shipment records for NNSA/NSO. The operator of the RWMC will take receipt of the waste after it has been unloaded, inspected, verified, and accepted by RWMC personnel.

\subsection{Funding and Forecasting}

For information regarding funding and forecasting requirements, contact the NNSA/NSO, Federal Sub-Project Director Low-Level Waste Project.

Generators shall fax (702-295-3112) or email (gordonsj@nv.doe.gov) a "Monthly Shipment Schedule" by the last Monday of each month that includes: ${ }^{7.19}$

- Estimated number of shipments and arrival dates for the upcoming month

- Waste profile number(s)

- Type and quantity of containers/packaging

- Identify special handling requirements, if applicable

\subsection{Disposition of Noncompliant Conditions}

NTS RWMC and RWAP personnel are responsible for identifying and documenting noncompliance issues (i.e., physical or documentation errors) discovered when conducting MW and LLW receipt and disposal activities. MW and radioactive waste shipments received at the NNSS that are not in compliance with requirements may be returned to the generator facility or require resolution from the generator. 
NNSA/NSO shall be notified of waste shipment noncompliance issues. ${ }^{7.6}$ Appropriate action will be initiated based upon the type of the noncompliance and the established program requirements. Generators may be charged for costs incurred for noncompliant waste shipments.

Generators shall work with NNSA/NSO and operator of the NNSS to ensure rejected shipments/containers of MW are returned to the generator or an alternate treatment, storage, or disposal facility within 60 days from the date of receipt at the NNSS. ${ }^{7.5}$ Generators shall be responsible for dispositioning rejected wastes and coordinating transportation and manifesting back to the generator's site or an alternate facility. ${ }^{7.5}$

\subsection{Waste Refusal}

LLW or MLLW shipments received at the NNSS that do not comply with the NNSSWAC requirements will not be accepted for disposal. RWMC operations personnel will be responsible for notifying the appropriate NNSA/NSO personnel regarding any refused radioactive or mixed waste shipments. Generators will be responsible for arranging timely return of rejected shipments. Reasons for waste shipment refusal include, but are not limited to, failure to have:

- Conforming package activity limits as specified in Section 3.2.2.

- Sufficient funding transferred to the operator of the NNSS to cover the cost of handling and disposal.

- A DOE/NRC Form 741 on file at the NNSS prior to the shipment's arrival.

- A signed certification statement accompanying the shipment.

- Successful verification performed on the waste containers in accordance with the NNSSWAC, NNSS Waste Analysis Plan, and applicable procedures.

- Written approval from MC\&A for shipment of accountable materials. 
This page intentionally left blank. 


\section{Appendix A}

\section{Waste Process Flow Diagrams}


This page intentionally left blank. 


\section{Appendix A - Waste Process Flow Diagram}

The following diagram identifies key process steps. Operations and logistics may influence the order in which these activities are conducted. Technical support may be requested at any time by the generator (Section 2.5).

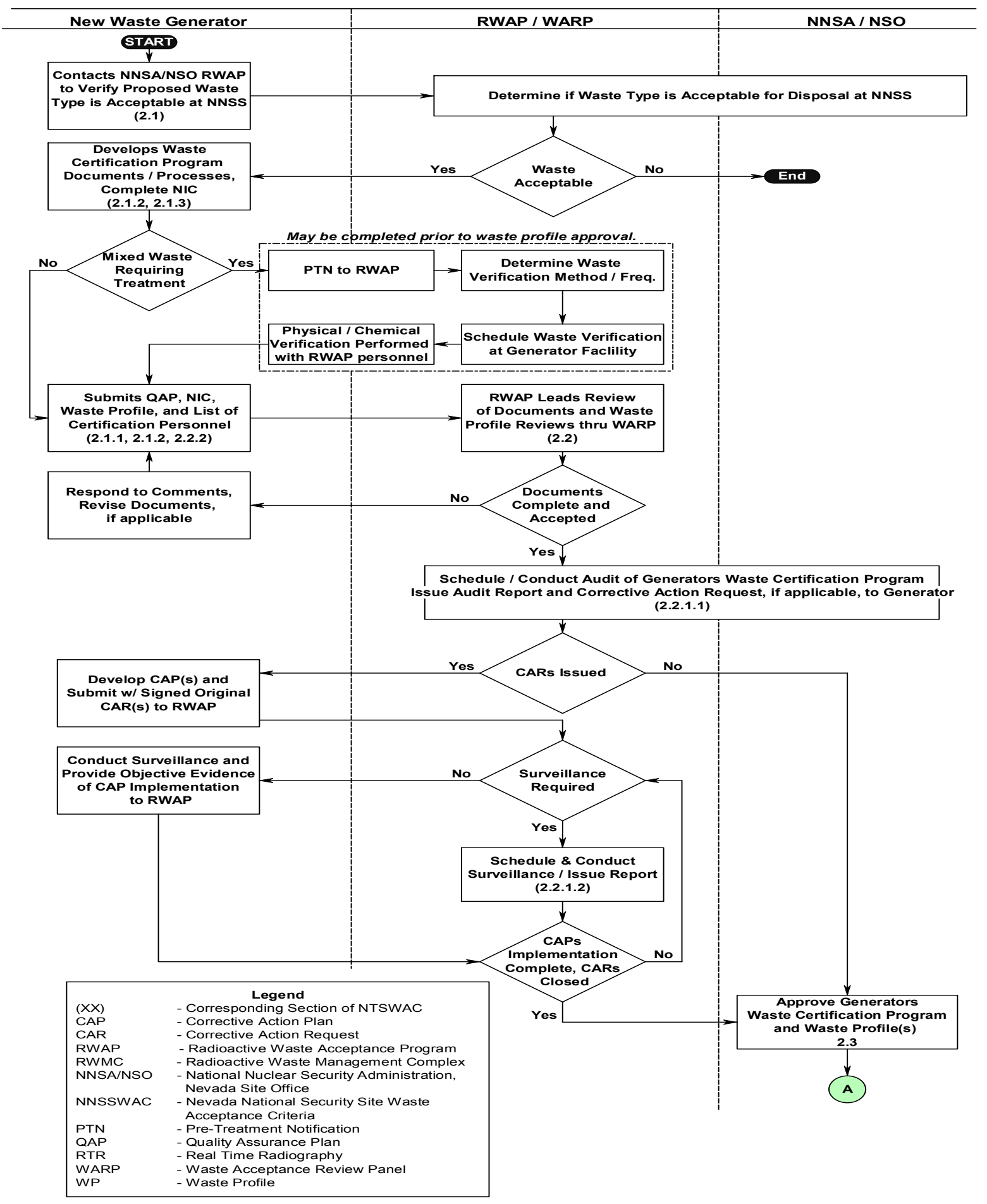


Appendix A - Waste Process Flow Diagram (continued)

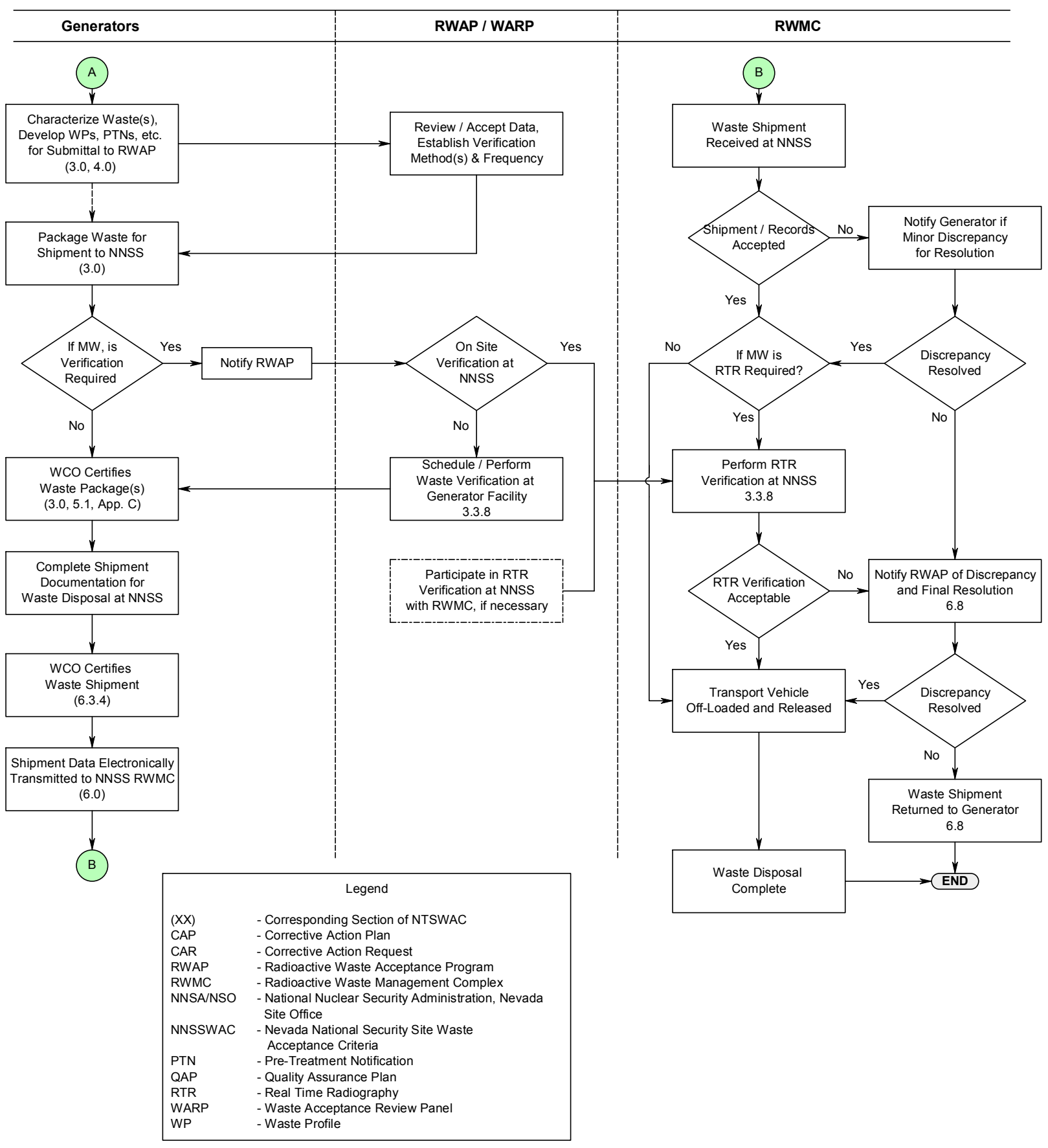




\section{Waste Profile Approval Process}

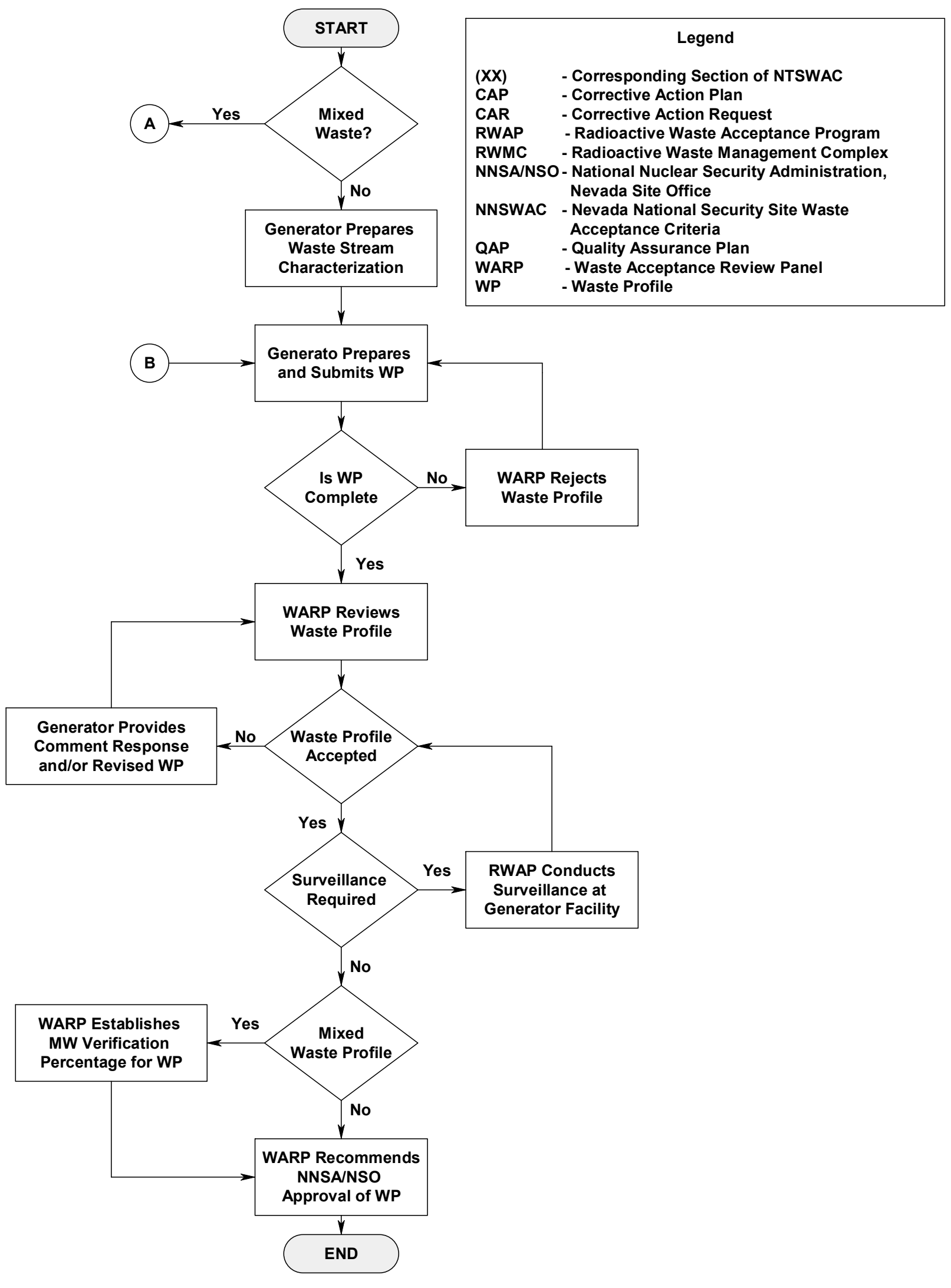




\section{Waste Profile Approval Process (continued)}
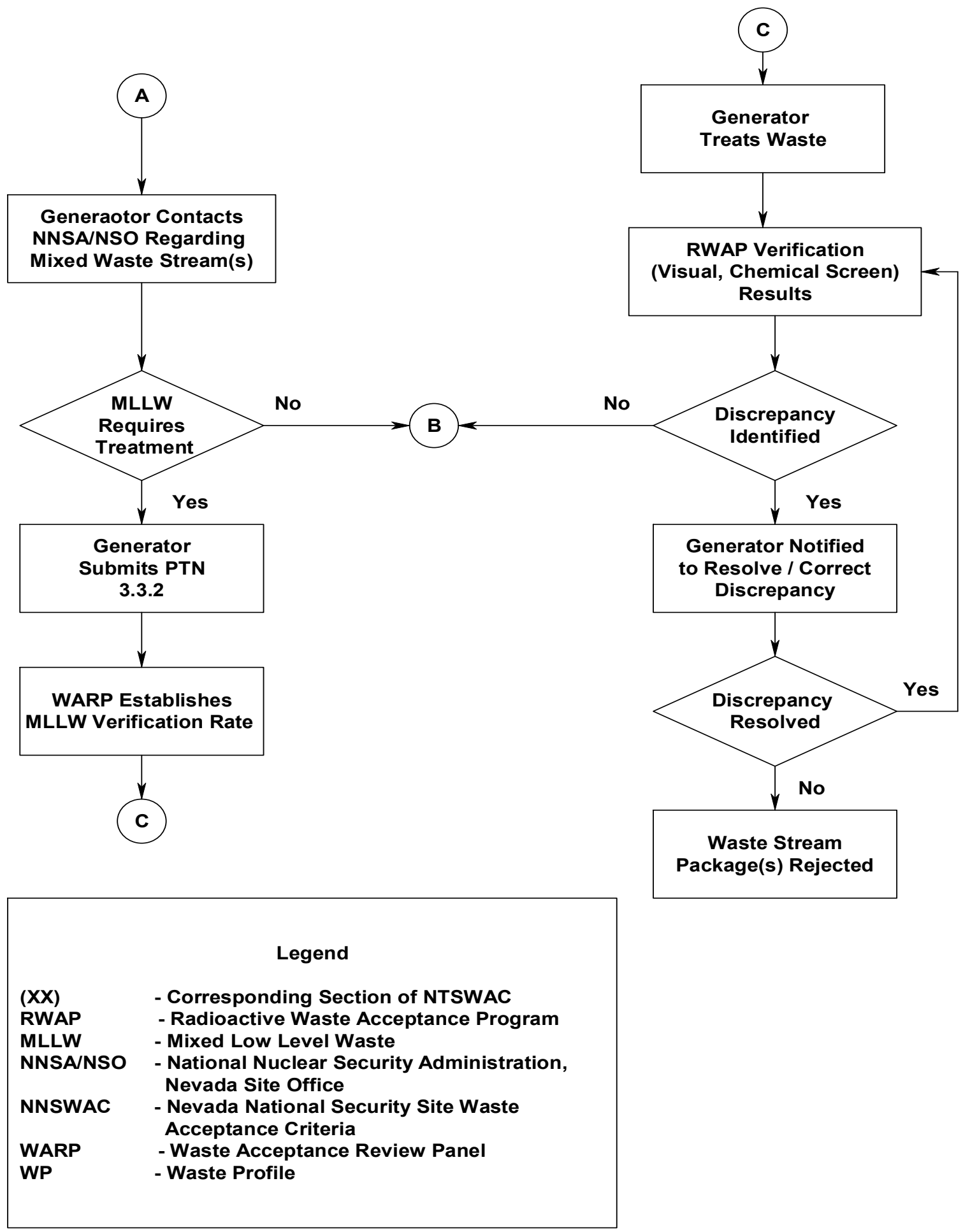


\section{Document and Personnel Changes}

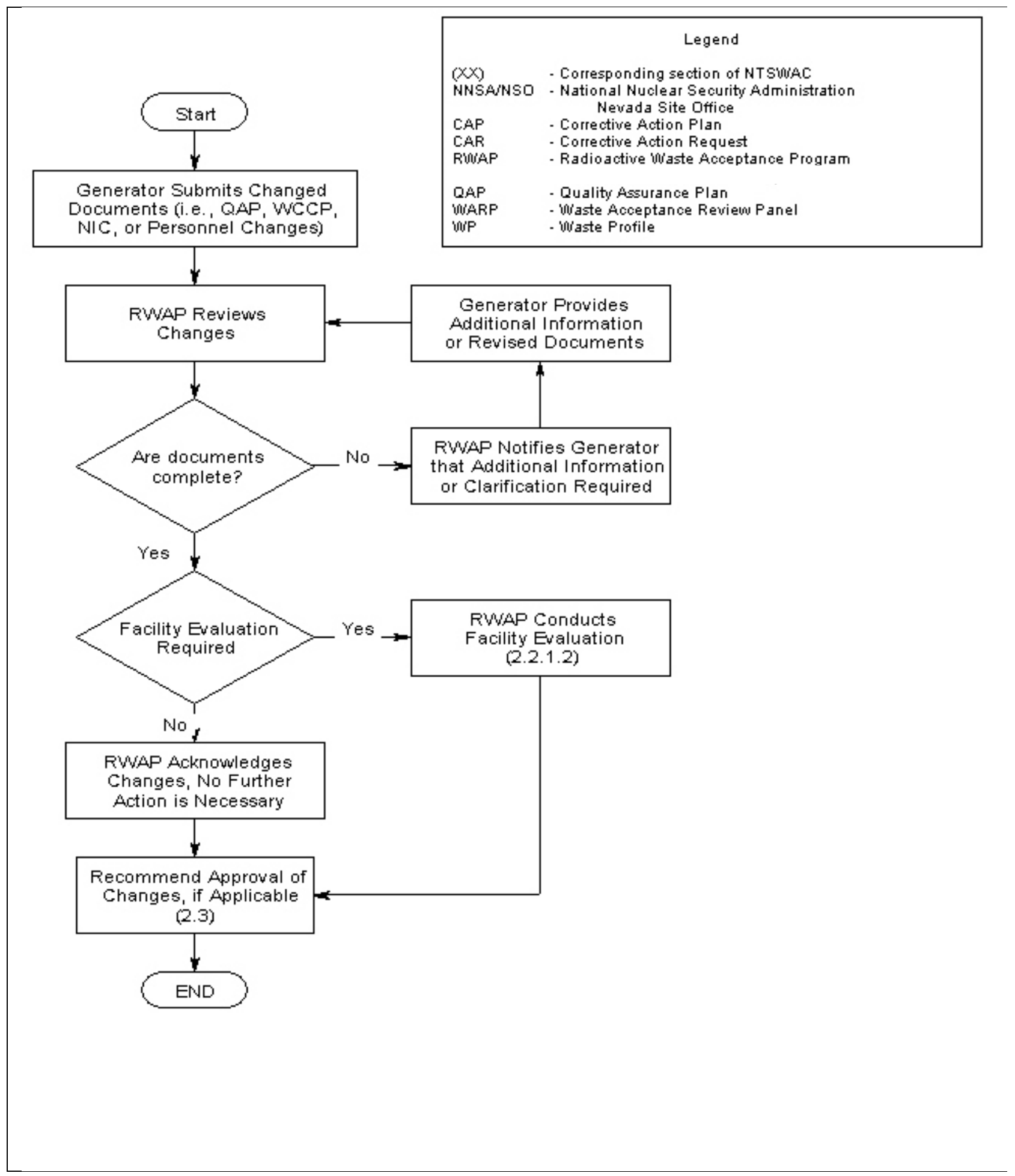


This page intentionally left blank. 


\section{Appendix B}

\section{Plutonium Equivalent Gram (PE-g) Radionuclide Conversion Factors}


This page intentionally left blank. 


\section{Appendix B - Plutonium Equivalent Gram (PE-g) Radionuclide Conversion Factors}

* Note: For isotopes not having a direct PE-g conversion factor, the total activity shall be treated as Pu-239 for alpha emission and as Cs-137 for beta/gamma emission. ${ }^{7.18}$

\begin{tabular}{|l|l|}
\hline \multicolumn{2}{|l|}{$\begin{array}{l}\text { Nuclide CONVERSION } \\
\text { FACTORS ----PE-g/Bq }\end{array}$} \\
\hline Ac-224 & $3.31 \mathrm{E}-12$ \\
\hline Ac-225 & $2.33 \mathrm{E}-10$ \\
\hline Ac-226 & $3.54 \mathrm{E}-11$ \\
\hline Ac-227 & $4.28 \mathrm{E}-09$ \\
\hline Ac-228 & $4.01 \mathrm{E}-13$ \\
\hline Ag-102 & $4.92 \mathrm{E}-16$ \\
\hline Ag-103 & $7.51 \mathrm{E}-16$ \\
\hline Ag-104 & $1.03 \mathrm{E}-15$ \\
\hline Ag-104m & $7.04 \mathrm{E}-16$ \\
\hline Ag-105 & $2.25 \mathrm{E}-14$ \\
\hline Ag-106 & $4.27 \mathrm{E}-16$ \\
\hline Ag-106m & $3.09 \mathrm{E}-14$ \\
\hline Ag-108m & $1.04 \mathrm{E}-12$ \\
\hline Ag-110m & $3.40 \mathrm{E}-13$ \\
\hline Ag-111 & $4.74 \mathrm{E}-14$ \\
\hline Ag-112 & $4.79 \mathrm{E}-15$ \\
\hline Ag-115 & $7.95 \mathrm{E}-16$ \\
\hline Al-26 & $3.00 \mathrm{E}-12$ \\
\hline Am-237 & $7.18 \mathrm{E}-16$ \\
\hline Am-238 & $5.18 \mathrm{E}-15$ \\
\hline Am-239 & $6.52 \mathrm{E}-15$ \\
\hline Am-240 & $1.19 \mathrm{E}-14$ \\
\hline Am-241 & $2.65 \mathrm{E}-09$ \\
\hline Am-242 & $5.42 \mathrm{E}-13$ \\
\hline Am-242m & $2.53 \mathrm{E}-09$ \\
\hline Am-243 & $2.63 \mathrm{E}-09$ \\
\hline Am-244 & $1.02 \mathrm{E}-13$ \\
\hline Am-244m & $4.42 \mathrm{E}-15$ \\
\hline Am-245 & $1.55 \mathrm{E}-15$ \\
\hline Am-246 & $1.91 \mathrm{E}-15$ \\
\hline Am-246m & $6.46 \mathrm{E}-16$ \\
\hline As-69 & $6.06 \mathrm{E}-16$ \\
\hline As-70 & $1.92 \mathrm{E}-15$ \\
\hline As-71 & $1.10 \mathrm{E}-14$ \\
\hline As-72 & $2.61 \mathrm{E}-14$ \\
\hline As-73 & $3.72 \mathrm{E}-14$ \\
\hline As-74 & $6.89 \mathrm{E}-14$ \\
\hline As-76 & $2.16 \mathrm{E}-14$ \\
\hline As-77 & $1.18 \mathrm{E}-14$ \\
\hline As-78 & $2.57 \mathrm{E}-15$ \\
\hline At-207 & $7.04 \mathrm{E}-14$ \\
\hline At-211 & $3.27 \mathrm{E}-12$ \\
\hline Au-193 & $3.28 \mathrm{E}-15$ \\
\hline Au-194 & $6.70 \mathrm{E}-15$ \\
\hline Au-195 & $4.82 \mathrm{E}-14$ \\
\hline Au-198 & $2.36 \mathrm{E}-14$ \\
\hline Au-198m & $5.34 \mathrm{E}-14$ \\
\hline Au-199 & $2.17 \mathrm{E}-14$ \\
\hline Au-200 & $9.66 \mathrm{E}-16$ \\
\hline Au-200m & $2.01 \mathrm{E}-14$ \\
\hline Au-201 & $4.86 \mathrm{E}-16$ \\
\hline & \\
\hline
\end{tabular}

\begin{tabular}{|l|l|}
\hline \multicolumn{2}{|l|}{$\begin{array}{l}\text { Nuclide CONVERSION } \\
\text { FACTORS --- PE-g/Bq }\end{array}$} \\
\hline Ba-126 & $2.93 \mathrm{E}-15$ \\
\hline Ba-128 & $3.74 \mathrm{E}-14$ \\
\hline Ba-131 & $2.38 \mathrm{E}-14$ \\
\hline Ba-131m & $2.14 \mathrm{E}-16$ \\
\hline Ba-133 & $2.83 \mathrm{E}-13$ \\
\hline Ba-133m & $1.27 \mathrm{E}-14$ \\
\hline Ba-135m & $9.88 \mathrm{E}-15$ \\
\hline Ba-139 & $1.61 \mathrm{E}-15$ \\
\hline Ba-140 & $1.61 \mathrm{E}-13$ \\
\hline Ba-141 & $9.36 \mathrm{E}-16$ \\
\hline Ba-142 & $6.03 \mathrm{E}-16$ \\
\hline Be-7 & $1.52 \mathrm{E}-15$ \\
\hline Be-10 & $9.51 \mathrm{E}-13$ \\
\hline Bi-200 & $9.59 \mathrm{E}-16$ \\
\hline Bi-201 & $1.92 \mathrm{E}-15$ \\
\hline Bi-202 & $1.58 \mathrm{E}-15$ \\
\hline Bi-203 & $7.73 \mathrm{E}-15$ \\
\hline Bi-205 & $2.91 \mathrm{E}-14$ \\
\hline Bi-206 & $5.06 \mathrm{E}-14$ \\
\hline Bi-207 & $1.07 \mathrm{E}-12$ \\
\hline Bi-210 & $3.65 \mathrm{E}-12$ \\
\hline Bi-210m & $2.72 \mathrm{E}-10$ \\
\hline Bi-212 & $9.14 \mathrm{E}-13$ \\
\hline Bi-213 & $8.77 \mathrm{E}-13$ \\
\hline Bi-214 & $4.23 \mathrm{E}-13$ \\
\hline Bk-245 & $6.20 \mathrm{E}-14$ \\
\hline Bk-246 & $9.21 \mathrm{E}-15$ \\
\hline Bk-247 & $4.59 \mathrm{E}-09$ \\
\hline Bk-249 & $1.11 \mathrm{E}-11$ \\
\hline Bk-250 & $5.74 \mathrm{E}-14$ \\
\hline Br-74 & $1.09 \mathrm{E}-15$ \\
\hline Br-74m & $1.77 \mathrm{E}-15$ \\
\hline Br-75 & $1.56 \mathrm{E}-15$ \\
\hline Br-76 & $1.20 \mathrm{E}-14$ \\
\hline Br-77 & $2.42 \mathrm{E}-15$ \\
\hline Br-80 & $2.84 \mathrm{E}-16$ \\
\hline Br-80m & $2.28 \mathrm{E}-15$ \\
\hline Br-82 & $1.83 \mathrm{E}-14$ \\
\hline Br-83 & $1.45 \mathrm{E}-15$ \\
\hline Br-84 & $1.06 \mathrm{E}-15$ \\
\hline C-11 & $5.08 \mathrm{E}-16$ \\
\hline C-14 & $1.58 \mathrm{E}-13$ \\
\hline Ca-41 & $4.98 \mathrm{E}-15$ \\
\hline Ca-45 & $1.00 \mathrm{E}-13$ \\
\hline Ca-47 -13 \\
\hline Cd-104 & $5.80 \mathrm{E}-14$ \\
\hline Cd-107 & $9.66 \mathrm{E}-16$ \\
\hline Cd-109 & $2.30 \mathrm{E}-15$ \\
\hline Cd-113 & $2.24 \mathrm{E}-13$ \\
\hline Cd-113m & $3.29 \mathrm{E}-12$ \\
\hline Cd-115 & $3.02 \mathrm{E}-12$ \\
\hline & $2.95 \mathrm{E}-14$ \\
\hline
\end{tabular}

\begin{tabular}{|l|l|}
\hline \multicolumn{2}{|l|}{$\begin{array}{l}\text { Nuclide CONVERSION } \\
\text { FACTORS --- PE-g / Bq }\end{array}$} \\
\hline Cd-115m & $2.10 \mathrm{E}-13$ \\
\hline Cd-117 & $4.70 \mathrm{E}-15$ \\
\hline Cd-117m & $5.71 \mathrm{E}-15$ \\
\hline Ce-134 & $3.71 \mathrm{E}-14$ \\
\hline Ce-135 & $1.39 \mathrm{E}-14$ \\
\hline Ce-137 & $2.88 \mathrm{E}-16$ \\
\hline Ce-137m & $1.22 \mathrm{E}-14$ \\
\hline Ce-139 & $5.28 \mathrm{E}-14$ \\
\hline Ce-141 & $1.03 \mathrm{E}-13$ \\
\hline Ce-143 & $2.29 \mathrm{E}-14$ \\
\hline Ce-144 & $1.45 \mathrm{E}-12$ \\
\hline Cf-244 & $3.91 \mathrm{E}-13$ \\
\hline Cf-246 & $1.38 \mathrm{E}-11$ \\
\hline Cf-248 & $3.10 \mathrm{E}-10$ \\
\hline Cf-249 & $4.61 \mathrm{E}-09$ \\
\hline Cf-250 & $2.02 \mathrm{E}-09$ \\
\hline Cf-251 & $4.70 \mathrm{E}-09$ \\
\hline Cf-252 & $5.50 \mathrm{E}-10$ \\
\hline Cf-253 & $4.44 \mathrm{E}-11$ \\
\hline Cf-254 & $1.13 \mathrm{E}-09$ \\
\hline Cl-36 & $1.04 \mathrm{E}-12$ \\
\hline Cl-38 & $1.30 \mathrm{E}-15$ \\
\hline Cl-39 & $1.34 \mathrm{E}-15$ \\
\hline Cm-238 & $1.22 \mathrm{E}-13$ \\
\hline Cm-240 & $9.59 \mathrm{E}-11$ \\
\hline Cm-241 & $1.03 \mathrm{E}-12$ \\
\hline Cm-242 & $1.63 \mathrm{E}-10$ \\
\hline Cm-243 & $1.91 \mathrm{E}-09$ \\
\hline Cm-244 & $1.57 \mathrm{E}-09$ \\
\hline Cm-245 & $2.71 \mathrm{E}-09$ \\
\hline Cm-246 & $2.68 \mathrm{E}-09$ \\
\hline Cm-247 & $2.47 \mathrm{E}-09$ \\
\hline Cm-248 & $9.90 \mathrm{E}-09$ \\
\hline Cm-249 & $1.11 \mathrm{E}-15$ \\
\hline Co-55 & $1.47 \mathrm{E}-14$ \\
\hline Co-56 & $1.86 \mathrm{E}-13$ \\
\hline Co-57 & $2.75 \mathrm{E}-14$ \\
\hline Co-58 & $5.82 \mathrm{E}-14$ \\
\hline Co-58m & $4.59 \mathrm{E}-16$ \\
\hline Co-60 & $8.47 \mathrm{E}-13$ \\
\hline Co-60m & $3.81 \mathrm{E}-17$ \\
\hline Co-61 & $1.40 \mathrm{E}-15$ \\
\hline Co-62m & $5.69 \mathrm{E}-16$ \\
\hline Cr-48 & $6.08 \mathrm{E}-15$ \\
\hline Cr-49 & $9.66 \mathrm{E}-16$ \\
\hline Cr-51 & $1.02 \mathrm{E}-15$ \\
\hline Cs-125 & $5.45 \mathrm{E}-16$ \\
\hline Cs-127 & $1.06 \mathrm{E}-15$ \\
\hline Cs-129 \\
\hline Cs-130 \\
\hline Cs-131 & 1.315 \\
\hline & \\
\hline
\end{tabular}


Nevada National Security Site Waste Acceptance Criteria

\begin{tabular}{|c|c|}
\hline \multicolumn{2}{|c|}{$\begin{array}{l}\text { Nuclide CONVERSION } \\
\text { FACTORS---PE-g / Bq }\end{array}$} \\
\hline Cs-132 & $8.40 \mathrm{E}-15$ \\
\hline Cs-134 & $5.61 \mathrm{E}-13$ \\
\hline Cs-134m & $1.64 \mathrm{E}-15$ \\
\hline Cs-135 & $2.35 \mathrm{E}-13$ \\
\hline Cs- $135 \mathrm{~m}$ & $4.32 \mathrm{E}-16$ \\
\hline Cs-136 & $7.65 \mathrm{E}-14$ \\
\hline Cs-137 & $1.08 \mathrm{E}-12$ \\
\hline Cs-138 & $1.18 \mathrm{E}-15$ \\
\hline $\mathrm{Cu}-60$ & $9.44 \mathrm{E}-16$ \\
\hline $\mathrm{Cu}-61$ & $2.16 \mathrm{E}-15$ \\
\hline $\mathrm{Cu}-64$ & $3.25 \mathrm{E}-15$ \\
\hline $\mathrm{Cu}-67$ & $1.66 \mathrm{E}-14$ \\
\hline Dy-155 & $2.25 \mathrm{E}-15$ \\
\hline Dy-157 & $8.55 \mathrm{E}-16$ \\
\hline Dy-159 & $1.21 \mathrm{E}-14$ \\
\hline Dy-165 & $1.77 \mathrm{E}-15$ \\
\hline Dy-166 & $5.73 \mathrm{E}-14$ \\
\hline Er-161 & $1.40 \mathrm{E}-15$ \\
\hline Er-165 & $2.31 \mathrm{E}-16$ \\
\hline Er-169 & $3.19 \mathrm{E}-14$ \\
\hline Er-171 & $6.45 \mathrm{E}-15$ \\
\hline Er-172 & $3.37 \mathrm{E}-14$ \\
\hline Es-250 & 3.72E-14 \\
\hline Es-251 & $5.89 \mathrm{E}-14$ \\
\hline Es-253 & $8.69 \mathrm{E}-11$ \\
\hline Es-254 & $2.79 \mathrm{E}-10$ \\
\hline Es-254m & $1.42 \mathrm{E}-11$ \\
\hline Eu-145 & $1.58 \mathrm{E}-14$ \\
\hline Eu-146 & $2.28 \mathrm{E}-14$ \\
\hline Eu-147 & $3.23 \mathrm{E}-14$ \\
\hline Eu-148 & $9.74 \mathrm{E}-14$ \\
\hline Eu-149 & $9.88 \mathrm{E}-15$ \\
\hline $\mathrm{Eu}-150 \mathrm{hr}$ & $5.63 \mathrm{E}-15$ \\
\hline Eu-150yr & $3.46 \mathrm{E}-12$ \\
\hline Eu-152 & $2.57 \mathrm{E}-12$ \\
\hline Eu-152m & 5.99E-15 \\
\hline Eu-154 & $3.04 \mathrm{E}-12$ \\
\hline Eu-155 & $3.44 \mathrm{E}-13$ \\
\hline Eu-156 & $1.06 \mathrm{E}-13$ \\
\hline Eu-157 & $8.55 \mathrm{E}-15$ \\
\hline Eu-158 & $1.35 \mathrm{E}-15$ \\
\hline F-18 & $1.62 \mathrm{E}-15$ \\
\hline $\mathrm{Fe}-52$ & $1.75 \mathrm{E}-14$ \\
\hline Fe-55 & $2.15 \mathrm{E}-14$ \\
\hline Fe-59 & $1.11 \mathrm{E}-13$ \\
\hline $\mathrm{Fe}-60$ & $7.73 \mathrm{E}-12$ \\
\hline Fm-252 & $9.66 \mathrm{E}-12$ \\
\hline Fm-253 & $1.26 \mathrm{E}-11$ \\
\hline Fm-254 & $1.81 \mathrm{E}-12$ \\
\hline Fm-255 & $8.10 \mathrm{E}-12$ \\
\hline Fm-257 & $2.27 \mathrm{E}-10$ \\
\hline Fr-222 & $7.65 \mathrm{E}-13$ \\
\hline Fr-223 & $3.31 \mathrm{E}-13$ \\
\hline Ga-65 & 4.79E-16 \\
\hline Ga-66 & $1.27 \mathrm{E}-14$ \\
\hline
\end{tabular}

\begin{tabular}{|c|c|}
\hline \multicolumn{2}{|c|}{$\begin{array}{l}\text { Nuclide CONVERSION } \\
\text { FACTORS --- PE-g / Bq } \\
\end{array}$} \\
\hline Ga-67 & $7.23 \mathrm{E}-15$ \\
\hline Ga-68 & $1.42 \mathrm{E}-15$ \\
\hline Ga-70 & $4.55 \mathrm{E}-16$ \\
\hline Ga-72 & $1.52 \mathrm{E}-14$ \\
\hline Ga-73 & $4.25 \mathrm{E}-15$ \\
\hline Gd-145 & $5.65 \mathrm{E}-16$ \\
\hline Gd-146 & $2.01 \mathrm{E}-13$ \\
\hline Gd-147 & $1.17 \mathrm{E}-14$ \\
\hline Gd-148 & 7.09E-10 \\
\hline Gd-149 & $2.21 \mathrm{E}-14$ \\
\hline Gd-151 & $2.73 \mathrm{E}-14$ \\
\hline Gd-152 & $5.23 \mathrm{E}-10$ \\
\hline Gd-153 & $6.59 \mathrm{E}-14$ \\
\hline Gd-159 & $8.17 \mathrm{E}-15$ \\
\hline Ge-66 & $2.62 \mathrm{E}-15$ \\
\hline Ge-67 & $7.07 \mathrm{E}-16$ \\
\hline Ge-68 & 8.77E-13 \\
\hline Ge-69 & $8.40 \mathrm{E}-15$ \\
\hline Ge-71 & $3.28 \mathrm{E}-16$ \\
\hline Ge-75 & $1.06 \mathrm{E}-15$ \\
\hline Ge-77 & $1.08 \mathrm{E}-14$ \\
\hline Ge-78 & $2.78 \mathrm{E}-15$ \\
\hline $\mathrm{H}-3$ & $7.21 \mathrm{E}-15$ \\
\hline Hf-170 & $9.44 \mathrm{E}-15$ \\
\hline Hf-172 & $8.92 \mathrm{E}-13$ \\
\hline Hf-173 & $4.82 \mathrm{E}-15$ \\
\hline Hf-175 & 3.92E-14 \\
\hline Hf-177m & $2.60 \mathrm{E}-15$ \\
\hline Hf- $178 \mathrm{~m}$ & $7.30 \mathrm{E}-12$ \\
\hline Hf-179m & $1.21 \mathrm{E}-13$ \\
\hline Hf-180m & $3.90 \mathrm{E}-15$ \\
\hline Hf-181 & $1.63 \mathrm{E}-13$ \\
\hline Hf-182 & $8.47 \mathrm{E}-12$ \\
\hline Hf-182m & $1.35 \mathrm{E}-15$ \\
\hline Hf-183 & $1.72 \mathrm{E}-15$ \\
\hline Hf-184 & $9.74 \mathrm{E}-15$ \\
\hline $\mathrm{Hg}-193$ & $2.21 \mathrm{E}-15$ \\
\hline $\mathrm{Hg}-193 \mathrm{~m}$ & $7.51 \mathrm{E}-15$ \\
\hline Hg-194 & $6.53 \mathrm{E}-13$ \\
\hline $\mathrm{Hg}-195$ & $2.21 \mathrm{E}-15$ \\
\hline $\mathrm{Hg}-195 \mathrm{~m}$ & $1.61 \mathrm{E}-14$ \\
\hline $\mathrm{Hg}-197$ & $9.29 \mathrm{E}-15$ \\
\hline $\mathrm{Hg}-197 \mathrm{~m}$ & $1.61 \mathrm{E}-14$ \\
\hline $\mathrm{Hg}-199 \mathrm{~m}$ & $9.29 \mathrm{E}-16$ \\
\hline $\mathrm{Hg}-203$ & $8.03 \mathrm{E}-14$ \\
\hline Ho-155 & $5.88 \mathrm{E}-16$ \\
\hline Но-157 & $1.23 \mathrm{E}-16$ \\
\hline Но-159 & $1.78 \mathrm{E}-16$ \\
\hline Ho-161 & $1.82 \mathrm{E}-16$ \\
\hline Но-162 & $8.17 \mathrm{E}-17$ \\
\hline Ho-162m & $6.24 \mathrm{E}-16$ \\
\hline Но-164 & $2.44 \mathrm{E}-16$ \\
\hline Ho-164m & $3.31 \mathrm{E}-16$ \\
\hline Но-166 & $1.93 \mathrm{E}-14$ \\
\hline Ho-166m & $7.88 \mathrm{E}-12$ \\
\hline
\end{tabular}

\begin{tabular}{|c|c|}
\hline \multicolumn{2}{|c|}{$\begin{array}{c}\text { Nuclide CONVERSION } \\
\text { FACTORS ---- PE-g / Bq } \\
\end{array}$} \\
\hline Нo-167 & $2.09 \mathrm{E}-15$ \\
\hline I-120 & $2.85 \mathrm{E}-15$ \\
\hline $\mathrm{I}-120 \mathrm{~m}$ & $2.43 \mathrm{E}-15$ \\
\hline $\mathrm{I}-121$ & $7.58 \mathrm{E}-16$ \\
\hline $\mathrm{I}-123$ & $2.07 \mathrm{E}-15$ \\
\hline $\mathrm{I}-124$ & $1.22 \mathrm{E}-13$ \\
\hline $\mathrm{I}-125$ & $1.43 \mathrm{E}-13$ \\
\hline $\mathrm{I}-126$ & $2.71 \mathrm{E}-13$ \\
\hline I-128 & $5.38 \mathrm{E}-16$ \\
\hline $\mathrm{I}-129$ & $9.88 \mathrm{E}-13$ \\
\hline $\mathrm{I}-130$ & $1.86 \mathrm{E}-14$ \\
\hline $\mathrm{I}-131$ & $2.03 \mathrm{E}-13$ \\
\hline $\mathrm{I}-132$ & $3.14 \mathrm{E}-15$ \\
\hline $\mathrm{I}-132 \mathrm{~m}$ & $2.47 \mathrm{E}-15$ \\
\hline $\mathrm{I}-133$ & $4.03 \mathrm{E}-14$ \\
\hline $\mathrm{I}-134$ & $1.54 \mathrm{E}-15$ \\
\hline I-135 & $8.84 \mathrm{E}-15$ \\
\hline In-109 & $1.23 \mathrm{E}-15$ \\
\hline In-110min & $1.36 \mathrm{E}-15$ \\
\hline In-110hr & $3.62 \mathrm{E}-15$ \\
\hline In-111 & $6.73 \mathrm{E}-15$ \\
\hline In-112 & $2.13 \mathrm{E}-16$ \\
\hline In-113m & $5.77 \mathrm{E}-16$ \\
\hline In-114m & $2.57 \mathrm{E}-13$ \\
\hline In-115 & $1.07 \mathrm{E}-11$ \\
\hline In-115m & $1.72 \mathrm{E}-15$ \\
\hline In-116m & $1.31 \mathrm{E}-15$ \\
\hline In-117 & $8.40 \mathrm{E}-16$ \\
\hline In-117m & $2.10 \mathrm{E}-15$ \\
\hline In-119m & 4.99E-16 \\
\hline Ir-182 & $6.80 \mathrm{E}-16$ \\
\hline Ir-184 & $3.22 \mathrm{E}-15$ \\
\hline Ir-185 & $5.25 \mathrm{E}-15$ \\
\hline Ir-186 & $1.21 \mathrm{E}-15$ \\
\hline Ir-187 & $2.18 \mathrm{E}-15$ \\
\hline Ir-188 & $1.17 \mathrm{E}-14$ \\
\hline Ir-189 & $1.67 \mathrm{E}-14$ \\
\hline Ir-190 & $6.45 \mathrm{E}-14$ \\
\hline Ir-190m & $2.84 \mathrm{E}-16$ \\
\hline Ir-192 & $1.82 \mathrm{E}-13$ \\
\hline Ir- $192 \mathrm{~m}$ & $1.08 \mathrm{E}-12$ \\
\hline Ir-194 & $1.53 \mathrm{E}-14$ \\
\hline Ir-194m & $3.49 \mathrm{E}-13$ \\
\hline Ir-195 & $1.97 \mathrm{E}-15$ \\
\hline Ir-195m & $4.67 \mathrm{E}-15$ \\
\hline $\mathrm{K}-40$ & $2.33 \mathrm{E}-12$ \\
\hline $\mathrm{K}-42$ & $9.81 \mathrm{E}-15$ \\
\hline K-43 & $1.06 \mathrm{E}-14$ \\
\hline K-44 & $9.07 \mathrm{E}-16$ \\
\hline K-45 & $6.81 \mathrm{E}-16$ \\
\hline $\mathrm{Kr}-85$ & $2.31 \mathrm{E}-23$ \\
\hline La-131 & $6.64 \mathrm{E}-16$ \\
\hline La-132 & 4.72E-15 \\
\hline La-135 & $4.06 \mathrm{E}-16$ \\
\hline La-137 & $2.42 \mathrm{E}-13$ \\
\hline
\end{tabular}




\begin{tabular}{|c|c|}
\hline \multicolumn{2}{|c|}{$\begin{array}{l}\text { Nuclide CONVERSION } \\
\text { FACTORS --- PE-g / Bq }\end{array}$} \\
\hline La-138 & $4.29 \mathrm{E}-12$ \\
\hline La-140 & 3.13E-14 \\
\hline La-141 & $4.33 \mathrm{E}-15$ \\
\hline La-142 & $2.59 \mathrm{E}-15$ \\
\hline La-143 & $6.22 \mathrm{E}-16$ \\
\hline Lu-169 & $1.06 \mathrm{E}-14$ \\
\hline Lu-170 & $1.84 \mathrm{E}-14$ \\
\hline Lu-171 & $2.42 \mathrm{E}-14$ \\
\hline Lu-172 & $4.28 \mathrm{E}-14$ \\
\hline Lu-173 & $8.84 \mathrm{E}-14$ \\
\hline Lu-174 & $1.90 \mathrm{E}-13$ \\
\hline Lu-174m & $1.16 \mathrm{E}-13$ \\
\hline Lu-176 & 4.13E-12 \\
\hline Lu-176m & $3.17 \mathrm{E}-15$ \\
\hline Lu-177 & $3.29 \mathrm{E}-14$ \\
\hline Lu-177m & $4.44 \mathrm{E}-13$ \\
\hline Lu-178 & $7.04 \mathrm{E}-16$ \\
\hline Lu-178m & $9.21 \mathrm{E}-16$ \\
\hline Lu-179 & $3.02 \mathrm{E}-15$ \\
\hline Md-257 & $7.88 \mathrm{E}-13$ \\
\hline Md-258 & $1.79 \mathrm{E}-10$ \\
\hline Mg-28 & $3.49 \mathrm{E}-14$ \\
\hline $\mathrm{Mn}-51$ & $1.19 \mathrm{E}-15$ \\
\hline Mn-52 & $3.92 \mathrm{E}-14$ \\
\hline Mn-52m & $8.10 \mathrm{E}-16$ \\
\hline Mn-53 & $9.36 \mathrm{E}-15$ \\
\hline Mn-54 & $8.99 \mathrm{E}-14$ \\
\hline Mn-56 & $3.53 \mathrm{E}-15$ \\
\hline Mo-101 & 7.19E-16 \\
\hline Mo-90 & $9.96 \mathrm{E}-15$ \\
\hline Mo-93 & $6.39 \mathrm{E}-14$ \\
\hline Mo-93m & $4.71 \mathrm{E}-15$ \\
\hline Mo-99 & 2.73E-14 \\
\hline $\mathrm{Na}-22$ & $8.03 \mathrm{E}-13$ \\
\hline $\mathrm{Na}-24$ & $1.37 \mathrm{E}-14$ \\
\hline $\mathrm{Nb}-88$ & $7.88 \mathrm{E}-16$ \\
\hline Nb-89(66) & $1.95 \mathrm{E}-15$ \\
\hline Nb-89(122) & $3.33 \mathrm{E}-15$ \\
\hline Nb-90 & $1.83 \mathrm{E}-14$ \\
\hline $\mathrm{Nb}-93 \mathrm{~m}$ & $4.87 \mathrm{E}-14$ \\
\hline $\mathrm{Nb}-94$ & $1.34 \mathrm{E}-12$ \\
\hline $\mathrm{Nb}-95$ & $4.82 \mathrm{E}-14$ \\
\hline $\mathrm{Nb}-95 \mathrm{~m}$ & $2.42 \mathrm{E}-14$ \\
\hline Nb-96 & $1.83 \mathrm{E}-14$ \\
\hline Nb-97 & $1.24 \mathrm{E}-15$ \\
\hline $\mathrm{Nb}-98$ & $1.61 \mathrm{E}-15$ \\
\hline Nd-136 & $1.49 \mathrm{E}-15$ \\
\hline Nd-138 & $6.81 \mathrm{E}-15$ \\
\hline Nd-139 & $2.88 \mathrm{E}-16$ \\
\hline Nd-139m & $4.30 \mathrm{E}-15$ \\
\hline Nd-141 & $1.43 \mathrm{E}-16$ \\
\hline Nd-147 & $6.60 \mathrm{E}-14$ \\
\hline Nd-149 & $2.53 \mathrm{E}-15$ \\
\hline Nd-151 & $4.94 \mathrm{E}-16$ \\
\hline $\mathrm{Ni}-56$ & $2.89 \mathrm{E}-14$ \\
\hline
\end{tabular}

\begin{tabular}{|l|l|}
\hline \multicolumn{2}{|c|}{ Nuclide CONVERSION } \\
FACTORS & - - PE-g / Bq \\
\hline Ni-57 & $1.46 \mathrm{E}-14$ \\
\hline Ni-59 & $1.22 \mathrm{E}-14$ \\
\hline Ni-63 & $3.46 \mathrm{E}-14$ \\
\hline Ni-65 & $2.47 \mathrm{E}-15$ \\
\hline Ni-66 & $4.94 \mathrm{E}-14$ \\
\hline Np-232 & $3.18 \mathrm{E}-15$ \\
\hline Np-233 & $4.68 \mathrm{E}-17$ \\
\hline Np-234 & $1.53 \mathrm{E}-14$ \\
\hline Np-235 & $1.72 \mathrm{E}-14$ \\
\hline Np-236hr & $2.48 \mathrm{E}-13$ \\
\hline Np-236yr & $2.18 \mathrm{E}-10$ \\
\hline Np-237 & $1.37 \mathrm{E}-09$ \\
\hline Np-238 & $9.59 \mathrm{E}-14$ \\
\hline Np-239 & $2.82 \mathrm{E}-14$ \\
\hline Np-240 & $2.49 \mathrm{E}-15$ \\
\hline Os-180 & $4.02 \mathrm{E}-16$ \\
\hline Os-181 & $1.79 \mathrm{E}-15$ \\
\hline Os-182 & $1.06 \mathrm{E}-14$ \\
\hline Os-185 & $4.45 \mathrm{E}-14$ \\
\hline Os-189m & $1.46 \mathrm{E}-16$ \\
\hline Os-191 & $5.26 \mathrm{E}-14$ \\
\hline Os-191m & $4.36 \mathrm{E}-15$ \\
\hline Os-193 & $1.44 \mathrm{E}-14$ \\
\hline Os-194 & $2.34 \mathrm{E}-12$ \\
\hline P-32 & $1.07 \mathrm{E}-13$ \\
\hline P-33 & $4.95 \mathrm{E}-14$ \\
\hline Pa-227 & $2.18 \mathrm{E}-12$ \\
\hline Pa-228 & $1.91 \mathrm{E}-12$ \\
\hline Pa-230 & $2.10 \mathrm{E}-11$ \\
\hline Pa-231 & $6.32 \mathrm{E}-09$ \\
\hline Pa-232 & $6.41 \mathrm{E}-14$ \\
\hline Pa-233 & $1.06 \mathrm{E}-13$ \\
\hline Pa-234 & $1.14 \mathrm{E}-14$ \\
\hline Pb-195m & $7.13 \mathrm{E}-16$ \\
\hline Pb-198 & $1.76 \mathrm{E}-15$ \\
\hline Pb-199 & $9.96 \mathrm{E}-16$ \\
\hline Pb-200 & $9.51 \mathrm{E}-15$ \\
\hline Pb-201 & $3.25 \mathrm{E}-15$ \\
\hline Pb-202 & $3.42 \mathrm{E}-13$ \\
\hline Pb-202m & $2.76 \mathrm{E}-15$ \\
\hline Pb-203 & $6.01 \mathrm{E}-15$ \\
\hline Pb-205 & $2.34 \mathrm{E}-14$ \\
\hline Pb-209 & $1.68 \mathrm{E}-15$ \\
\hline Pb-210 & $1.55 \mathrm{E}-10$ \\
\hline Pb-211 & $3.31 \mathrm{E}-13$ \\
\hline Pb-212 & $5.22 \mathrm{E}-12$ \\
\hline Pb-214 & $4.05 \mathrm{E}-13$ \\
\hline Pd-100 & $2.36 \mathrm{E}-14$ \\
\hline Pd-101 & $1.70 \mathrm{E}-15$ \\
\hline Pd-103 & $1.23 \mathrm{E}-14$ \\
\hline Pd-107 & $1.91 \mathrm{E}-14$ \\
\hline Pd-109 16 \\
\hline Pm-141 \\
\hline Pm-143 14 \\
\hline Pm-144 & $4.70 \mathrm{E}-13$ \\
\hline & \\
\hline & \\
\hline
\end{tabular}

\begin{tabular}{|l|l|}
\hline \multicolumn{2}{|c|}{ Nuclide CONVERSION } \\
FACTORS --- PE-g $/$ Bq \\
\hline Pm-145 & $2.32 \mathrm{E}-13$ \\
\hline Pm-146 & $1.22 \mathrm{E}-12$ \\
\hline Pm-147 & $1.92 \mathrm{E}-13$ \\
\hline Pm-148 & $5.97 \mathrm{E}-14$ \\
\hline Pm-148m & $1.58 \mathrm{E}-13$ \\
\hline Pm-149 & $1.99 \mathrm{E}-14$ \\
\hline Pm-150 & $3.63 \mathrm{E}-15$ \\
\hline Pm-151 & $1.30 \mathrm{E}-14$ \\
\hline Po-203 & $1.01 \mathrm{E}-15$ \\
\hline Po-205 & $1.91 \mathrm{E}-15$ \\
\hline Po-207 & $2.30 \mathrm{E}-15$ \\
\hline Po-210 & $1.17 \mathrm{E}-10$ \\
\hline Pr-136 & $3.78 \mathrm{E}-16$ \\
\hline Pr-137 & $5.76 \mathrm{E}-16$ \\
\hline Pr-138m & $2.06 \mathrm{E}-15$ \\
\hline Pr-139 & $5.45 \mathrm{E}-16$ \\
\hline Pr-142 & $1.52 \mathrm{E}-14$ \\
\hline Pr-142m & $1.93 \mathrm{E}-16$ \\
\hline Pr-143 & $6.71 \mathrm{E}-14$ \\
\hline Pr-144 & $5.03 \mathrm{E}-16$ \\
\hline Pr-145 & $4.61 \mathrm{E}-15$ \\
\hline Pr-147 & $5.20 \mathrm{E}-16$ \\
\hline Pt-186 & $1.59 \mathrm{E}-15$ \\
\hline Pt-188 & $5.38 \mathrm{E}-14$ \\
\hline Pt-189 & $2.73 \mathrm{E}-15$ \\
\hline Pt-191 & $7.80 \mathrm{E}-15$ \\
\hline Pt-193 & $1.84 \mathrm{E}-14$ \\
\hline Pt-193m & $2.68 \mathrm{E}-14$ \\
\hline Pt-195m & $3.17 \mathrm{E}-14$ \\
\hline Pt-197 & $9.59 \mathrm{E}-15$ \\
\hline Pt-197m & $2.18 \mathrm{E}-15$ \\
\hline Pt-199 & $7.95 \mathrm{E}-16$ \\
\hline Pt-200 & $1.69 \mathrm{E}-14$ \\
\hline Pu-234 & $6.52 \mathrm{E}-13$ \\
\hline Pu-235 & $4.16 \mathrm{E}-17$ \\
\hline Pu-236 & $2.88 \mathrm{E}-10$ \\
\hline Pu-237 & $1.08 \mathrm{E}-14$ \\
\hline Pu-238 & $4.42 \mathrm{E}-10$ \\
\hline Pu-239 & $4.41 \mathrm{E}-10$ \\
\hline Pu-240 & $4.41 \mathrm{E}-10$ \\
\hline Pu-241 & $4.80 \mathrm{E}-12$ \\
\hline Pu-242 & $4.13 \mathrm{E}-10$ \\
\hline Pu-243 & $2.38 \mathrm{E}-15$ \\
\hline Pu-244 & $3.43 \mathrm{E}-10$ \\
\hline Pu-245 & $1.20 \mathrm{E}-14$ \\
\hline Ra-223 & $2.39 \mathrm{E}-10$ \\
\hline Ra-224 & $9.21 \mathrm{E}-11$ \\
\hline Ra-225 & $2.13 \mathrm{E}-10$ \\
\hline Ra-226 & $2.62 \mathrm{E}-10$ \\
\hline Ra-227 -16 \\
\hline Ra-228 & $1.26 \mathrm{E}-15$ \\
\hline Rb-79 -16 \\
\hline Rb-81 & $3.95 \mathrm{E}-15$ \\
\hline Rb-81m & \\
\hline Rb-82m & \\
\hline & \\
\hline
\end{tabular}


Nevada National Security Site Waste Acceptance Criteria

\begin{tabular}{|c|c|}
\hline \multicolumn{2}{|c|}{$\begin{array}{l}\text { Nuclide CONVERSION } \\
\text { FACTORS --- PE-g / Bq } \\
\end{array}$} \\
\hline $\mathrm{Rb}-83$ & $3.98 \mathrm{E}-14$ \\
\hline $\mathrm{Rb}-84$ & $6.93 \mathrm{E}-14$ \\
\hline $\mathrm{Rb}-86$ & $1.29 \mathrm{E}-13$ \\
\hline $\mathrm{Rb}-87$ & $4.18 \mathrm{E}-13$ \\
\hline $\mathrm{Rb}-88$ & $7.58 \mathrm{E}-16$ \\
\hline $\mathrm{Rb}-89$ & $6.11 \mathrm{E}-16$ \\
\hline Re-177 & $4.03 \mathrm{E}-16$ \\
\hline Re-178 & $4.03 \mathrm{E}-16$ \\
\hline Re-181 & $7.18 \mathrm{E}-15$ \\
\hline Re-182(12.7) & $5.72 \mathrm{E}-15$ \\
\hline Re-182(64) & $3.57 \mathrm{E}-14$ \\
\hline Re-184 & $6.35 \mathrm{E}-14$ \\
\hline Re-184m & $2.76 \mathrm{E}-13$ \\
\hline Re-186 & $3.25 \mathrm{E}-14$ \\
\hline Re-186m & $1.70 \mathrm{E}-12$ \\
\hline Re-187 & $1.15 \mathrm{E}-15$ \\
\hline Re-188 & $1.50 \mathrm{E}-14$ \\
\hline Re-188m & $3.66 \mathrm{E}-16$ \\
\hline Re-189 & $1.26 \mathrm{E}-14$ \\
\hline Rh-99 & $2.41 \mathrm{E}-14$ \\
\hline Rh-99m & $1.11 \mathrm{E}-15$ \\
\hline Rh-100 & $9.81 \mathrm{E}-15$ \\
\hline Rh-101 & $1.49 \mathrm{E}-13$ \\
\hline Rh-101m & $5.76 \mathrm{E}-15$ \\
\hline Rh-102 & $4.82 \mathrm{E}-13$ \\
\hline Rh-102m & $1.97 \mathrm{E}-13$ \\
\hline Rh-103m & $7.51 \mathrm{E}-17$ \\
\hline Rh-105 & $9.66 \mathrm{E}-15$ \\
\hline Rh-106m & $3.04 \mathrm{E}-15$ \\
\hline Rh-107 & $4.58 \mathrm{E}-16$ \\
\hline Rn-220 & $1.66 \mathrm{E}-24$ \\
\hline Rn-222 & $1.71 \mathrm{E}-24$ \\
\hline Ru-94 & $1.22 \mathrm{E}-15$ \\
\hline Ru-97 & $3.00 \mathrm{E}-15$ \\
\hline Ru-103 & $8.10 \mathrm{E}-14$ \\
\hline Ru-105 & $4.93 \mathrm{E}-15$ \\
\hline Ru-106 & $1.81 \mathrm{E}-12$ \\
\hline S-35 & $5.12 \mathrm{E}-14$ \\
\hline Sb-115 & $3.76 \mathrm{E}-16$ \\
\hline Sb-116 & $3.60 \mathrm{E}-16$ \\
\hline Sb-116m & $1.35 \mathrm{E}-15$ \\
\hline Sb-117 & $4.82 \mathrm{E}-16$ \\
\hline Sb-118m & $3.37 \mathrm{E}-15$ \\
\hline Sb-119 & $1.03 \mathrm{E}-15$ \\
\hline Sb-120min & $2.01 \mathrm{E}-16$ \\
\hline Sb-120day & $3.02 \mathrm{E}-14$ \\
\hline $\mathrm{Sb}-122$ & $3.11 \mathrm{E}-14$ \\
\hline Sb-124 & $2.36 \mathrm{E}-13$ \\
\hline Sb-124m & $1.62 \mathrm{E}-16$ \\
\hline Sb-125 & $3.26 \mathrm{E}-13$ \\
\hline Sb-126 & $8.92 \mathrm{E}-14$ \\
\hline Sb-126m & $5.39 \mathrm{E}-16$ \\
\hline Sb-127 & $5.16 \mathrm{E}-14$ \\
\hline $\mathrm{Sb}-128 \mathrm{~min}$ & $4.08 \mathrm{E}-16$ \\
\hline
\end{tabular}

\begin{tabular}{|c|c|}
\hline \multicolumn{2}{|c|}{$\begin{array}{l}\text { Nuclide CONVERSION } \\
\text { FACTORS---- PE-g / Bq } \\
\end{array}$} \\
\hline Sb-128hr & $1.16 \mathrm{E}-14$ \\
\hline $\mathrm{Sb}-129$ & $6.87 \mathrm{E}-15$ \\
\hline Sb-130 & $1.48 \mathrm{E}-15$ \\
\hline $\mathrm{Sb}-131$ & $1.20 \mathrm{E}-15$ \\
\hline Sc-43 & $3.15 \mathrm{E}-15$ \\
\hline Sc-44 & $5.05 \mathrm{E}-15$ \\
\hline $\mathrm{Sc}-44 \mathrm{~m}$ & $3.94 \mathrm{E}-14$ \\
\hline Sc-46 & $1.86 \mathrm{E}-13$ \\
\hline Sc-47 & $1.99 \mathrm{E}-14$ \\
\hline Sc-48 & $3.07 \mathrm{E}-14$ \\
\hline Sc-49 & $1.09 \mathrm{E}-15$ \\
\hline Se-70 & $2.11 \mathrm{E}-15$ \\
\hline Se-73 & $5.77 \mathrm{E}-15$ \\
\hline Se-73m & $5.97 \mathrm{E}-16$ \\
\hline Se-75 & $3.67 \mathrm{E}-14$ \\
\hline Se-79 & $1.86 \mathrm{E}-13$ \\
\hline Se-81 & $4.04 \mathrm{E}-16$ \\
\hline $\mathrm{Se}-81 \mathrm{~m}$ & $1.40 \mathrm{E}-15$ \\
\hline Se-83 & $9.29 \mathrm{E}-16$ \\
\hline Si-31 & $2.17 \mathrm{E}-15$ \\
\hline Si-32 & $3.12 \mathrm{E}-12$ \\
\hline Sm-141 & $4.38 \mathrm{E}-16$ \\
\hline Sm-141m & $9.21 \mathrm{E}-16$ \\
\hline Sm-142 & $2.05 \mathrm{E}-15$ \\
\hline Sm-145 & $8.03 \mathrm{E}-14$ \\
\hline Sm-146 & $6.99 \mathrm{E}-10$ \\
\hline Sm-147 & $6.35 \mathrm{E}-10$ \\
\hline Sm-151 & $2.53 \mathrm{E}-13$ \\
\hline Sm-153 & $1.91 \mathrm{E}-14$ \\
\hline Sm-155 & $4.90 \mathrm{E}-16$ \\
\hline Sm-156 & $6.62 \mathrm{E}-15$ \\
\hline Sn-110 & $4.45 \mathrm{E}-15$ \\
\hline Sn-111 & $3.79 \mathrm{E}-16$ \\
\hline Sn-113 & $1.08 \mathrm{E}-13$ \\
\hline $\mathrm{Sn}-117 \mathrm{~m}$ & $7.73 \mathrm{E}-14$ \\
\hline Sn-119m & $9.14 \mathrm{E}-14$ \\
\hline Sn-121 & $6.84 \mathrm{E}-15$ \\
\hline Sn-121m & $4.12 \mathrm{E}-13$ \\
\hline Sn-123 & $3.54 \mathrm{E}-13$ \\
\hline Sn-123m & $7.80 \mathrm{E}-16$ \\
\hline Sn-125 & $9.66 \mathrm{E}-14$ \\
\hline Sn-126 & $4.25 \mathrm{E}-12$ \\
\hline Sn-127 & $3.95 \mathrm{E}-15$ \\
\hline Sn-128 & $2.68 \mathrm{E}-15$ \\
\hline Sr-80 & $3.74 \mathrm{E}-15$ \\
\hline Sr-81 & $1.02 \mathrm{E}-15$ \\
\hline Sr-83 & $9.36 \mathrm{E}-15$ \\
\hline Sr-85 & $2.26 \mathrm{E}-14$ \\
\hline Sr-85m & $1.19 \mathrm{E}-16$ \\
\hline Sr- $87 \mathrm{~m}$ & $5.80 \mathrm{E}-16$ \\
\hline Sr-89 & $2.18 \mathrm{E}-13$ \\
\hline Sr-90 & $4.32 \mathrm{E}-12$ \\
\hline Sr-91 & $1.12 \mathrm{E}-14$ \\
\hline Sr-92 & $6.23 \mathrm{E}-15$ \\
\hline
\end{tabular}

\begin{tabular}{|c|c|}
\hline \multicolumn{2}{|c|}{$\begin{array}{l}\text { Nuclide CONVERSION } \\
\text { FACTORS---- PE-g / Bq } \\
\end{array}$} \\
\hline Тa-172 & $9.66 \mathrm{E}-16$ \\
\hline Ta-173 & $3.20 \mathrm{E}-15$ \\
\hline Ta-174 & $1.19 \mathrm{E}-15$ \\
\hline Ta-175 & $3.69 \mathrm{E}-15$ \\
\hline Ta-176 & $5.53 \mathrm{E}-15$ \\
\hline Ta-177 & $2.87 \mathrm{E}-15$ \\
\hline Ta-178 & $1.88 \mathrm{E}-15$ \\
\hline Ta-179 & $1.56 \mathrm{E}-14$ \\
\hline Ta-180 & $7.04 \mathrm{E}-13$ \\
\hline Ta-180m & $1.22 \mathrm{E}-15$ \\
\hline Тa-182 & $2.87 \mathrm{E}-13$ \\
\hline Ta- $182 \mathrm{~m}$ & $5.89 \mathrm{E}-16$ \\
\hline Ta-183 & $6.00 \mathrm{E}-14$ \\
\hline Ta-184 & $1.21 \mathrm{E}-14$ \\
\hline Ta-185 & $1.34 \mathrm{E}-15$ \\
\hline Ta-186 & $5.02 \mathrm{E}-16$ \\
\hline Tb-147 & $2.21 \mathrm{E}-15$ \\
\hline Tb-149 & $1.49 \mathrm{E}-13$ \\
\hline Tb-150 & $3.14 \mathrm{E}-15$ \\
\hline Tb-151 & $6.61 \mathrm{E}-15$ \\
\hline Tb-153 & $5.67 \mathrm{E}-15$ \\
\hline Tb-154 & $1.05 \mathrm{E}-14$ \\
\hline Tb-155 & $6.61 \mathrm{E}-15$ \\
\hline Tb-156 & $3.35 \mathrm{E}-14$ \\
\hline Tb-156m (5.0) & $2.88 \mathrm{E}-15$ \\
\hline Tb-156m (24.4) & $6.41 \mathrm{E}-15$ \\
\hline Tb-157 & $8.17 \mathrm{E}-14$ \\
\hline Tb-158 & $2.88 \mathrm{E}-12$ \\
\hline Tb-160 & $2.27 \mathrm{E}-13$ \\
\hline Tb-161 & $3.86 \mathrm{E}-14$ \\
\hline Tc-101 & $3.40 \mathrm{E}-16$ \\
\hline Tc-104 & $7.88 \mathrm{E}-16$ \\
\hline Tc-93 & $9.81 \mathrm{E}-16$ \\
\hline Tc-93m & 4.79E-16 \\
\hline Tc-94 & $3.53 \mathrm{E}-15$ \\
\hline Tc-94m & $1.26 \mathrm{E}-15$ \\
\hline Tc-96 & $1.95 \mathrm{E}-14$ \\
\hline Tc-96m & $2.10 \mathrm{E}-16$ \\
\hline Tc-97 & $4.91 \mathrm{E}-14$ \\
\hline Tc-97m & $1.14 \mathrm{E}-13$ \\
\hline Tc-98 & $1.23 \mathrm{E}-12$ \\
\hline Tc-99 & $3.67 \mathrm{E}-13$ \\
\hline Tc-99m & $5.54 \mathrm{E}-16$ \\
\hline Te-116 & $3.05 \mathrm{E}-15$ \\
\hline Te-121 & $1.14 \mathrm{E}-14$ \\
\hline $\mathrm{Te}-121 \mathrm{~m}$ & $1.56 \mathrm{E}-13$ \\
\hline Te-123 & $1.08 \mathrm{E}-13$ \\
\hline Te-123m & $1.40 \mathrm{E}-13$ \\
\hline Te-125m & $1.14 \mathrm{E}-13$ \\
\hline Te-127 & $3.83 \mathrm{E}-15$ \\
\hline Te-127m & $2.69 \mathrm{E}-13$ \\
\hline Te-129 & $1.08 \mathrm{E}-15$ \\
\hline Te-129m & $2.18 \mathrm{E}-13$ \\
\hline Te-131 & $7.80 \mathrm{E}-16$ \\
\hline
\end{tabular}




\begin{tabular}{|c|c|}
\hline \multicolumn{2}{|c|}{$\begin{array}{l}\text { Nuclide CONVERSION } \\
\text { PACTORS ---- PE-g/Bq }\end{array}$} \\
\hline $\mathrm{Te}-131 \mathrm{~m}$ & $2.94 \mathrm{E}-14$ \\
\hline Te-132 & $5.64 \mathrm{E}-14$ \\
\hline Te-133 & $5.39 \mathrm{E}-16$ \\
\hline Te-133m & $2.44 \mathrm{E}-15$ \\
\hline Te-134 & $1.90 \mathrm{E}-15$ \\
\hline Th-226 & $1.69 \mathrm{E}-12$ \\
\hline Th-227 & $2.85 \mathrm{E}-10$ \\
\hline Th-228 & 1.09E-09 \\
\hline Th-229 & $6.58 \mathrm{E}-09$ \\
\hline Th-230 & $2.79 \mathrm{E}-09$ \\
\hline Th-231 & $9.21 \mathrm{E}-15$ \\
\hline Th-232 & $3.02 \mathrm{E}-09$ \\
\hline Th-234 & $2.12 \mathrm{E}-13$ \\
\hline Ti-44 & $3.43 \mathrm{E}-12$ \\
\hline Ti-45 & $2.57 \mathrm{E}-15$ \\
\hline Tl-194 & $1.62 \mathrm{E}-16$ \\
\hline Tl-194m & $8.55 \mathrm{E}-16$ \\
\hline Tl-195 & $7.36 \mathrm{E}-16$ \\
\hline Tl-197 & $1.06 \mathrm{E}-15$ \\
\hline Tl-198 & $2.06 \mathrm{E}-15$ \\
\hline Tl-198m & $1.90 \mathrm{E}-15$ \\
\hline Tl-199 & $1.31 \mathrm{E}-15$ \\
\hline $\mathrm{Tl}-200$ & $4.92 \mathrm{E}-15$ \\
\hline T1-201 & $5.31 \mathrm{E}-15$ \\
\hline Tl-202 & $1.08 \mathrm{E}-14$ \\
\hline Tl-204 & $5.22 \mathrm{E}-13$ \\
\hline Tm-162 & $4.53 \mathrm{E}-16$ \\
\hline Tm-166 & 4.99E-15 \\
\hline Tm-167 & $3.51 \mathrm{E}-14$ \\
\hline Tm-170 & $2.56 \mathrm{E}-13$ \\
\hline Tm-171 & $5.87 \mathrm{E}-14$ \\
\hline Tm-172 & $3.37 \mathrm{E}-14$ \\
\hline Tm-173 & $5.31 \mathrm{E}-15$ \\
\hline Tm-175 & $5.34 \mathrm{E}-16$ \\
\hline U-230 & $4.46 \mathrm{E}-10$ \\
\hline U-231 & $1.42 \mathrm{E}-14$ \\
\hline U-232 & $1.02 \mathrm{E}-09$ \\
\hline U-233 & $2.64 \mathrm{E}-10$ \\
\hline U-234 & $2.59 \mathrm{E}-10$ \\
\hline U-235 & $2.33 \mathrm{E}-10$ \\
\hline U-236 & $2.40 \mathrm{E}-10$ \\
\hline U-237 & $5.17 \mathrm{E}-14$ \\
\hline U-238 & $2.21 \mathrm{E}-10$ \\
\hline U-239 & $6.61 \mathrm{E}-16$ \\
\hline U-240 & $1.60 \mathrm{E}-14$ \\
\hline V-47 & $8.40 \mathrm{E}-16$ \\
\hline $\mathrm{V}-48$ & $7.40 \mathrm{E}-14$ \\
\hline $\mathrm{V}-49$ & $1.89 \mathrm{E}-15$ \\
\hline W-176 & $1.90 \mathrm{E}-15$ \\
\hline W-177 & $1.28 \mathrm{E}-15$ \\
\hline W-178 & $2.13 \mathrm{E}-14$ \\
\hline
\end{tabular}

\begin{tabular}{|c|c|}
\hline \multicolumn{2}{|c|}{$\begin{array}{l}\text { Nuclide CONVERSION } \\
\text { PACTORS ---- PE-g/Bq }\end{array}$} \\
\hline W-179 & "3.78E-17 \\
\hline W-181 & $7.51 \mathrm{E}-15$ \\
\hline W-185 & $1.06 \mathrm{E}-13$ \\
\hline W-187 & $1.15 \mathrm{E}-14$ \\
\hline W-188 & $4.27 \mathrm{E}-13$ \\
\hline $\mathrm{Xe}-120$ & $1.72 \mathrm{E}-21$ \\
\hline $\mathrm{Xe}-121$ & $8.30 \mathrm{E}-21$ \\
\hline Xe-122 & $2.12 \mathrm{E}-22$ \\
\hline Xe-123 & $2.71 \mathrm{E}-21$ \\
\hline $\mathrm{Xe}-125$ & $1.04 \mathrm{E}-21$ \\
\hline $\mathrm{Xe}-127$ & $1.09 \mathrm{E}-21$ \\
\hline $\mathrm{Xe}-129 \mathrm{~m}$ & $8.85 \mathrm{E}-23$ \\
\hline $\mathrm{Xe}-131 \mathrm{~m}$ & $3.38 \mathrm{E}-23$ \\
\hline $\mathrm{Xe}-133$ & $1.29 \mathrm{E}-22$ \\
\hline $\mathrm{Xe}-133 \mathrm{~m}$ & $1.24 \mathrm{E}-22$ \\
\hline $\mathrm{Xe}-135$ & $1.07 \mathrm{E}-21$ \\
\hline $\mathrm{Xe}-135 \mathrm{~m}$ & $1.83 \mathrm{E}-21$ \\
\hline Xe-138 & $5.28 \mathrm{E}-21$ \\
\hline Y-86 & $1.30 \mathrm{E}-14$ \\
\hline Y-86m & $7.88 \mathrm{E}-16$ \\
\hline Y-87 & $1.08 \mathrm{E}-14$ \\
\hline Y-88 & $1.69 \mathrm{E}-13$ \\
\hline Y-90 & $4.12 \mathrm{E}-14$ \\
\hline $\mathrm{Y}-90 \mathrm{~m}$ & $2.78 \mathrm{E}-15$ \\
\hline Y-91 & $2.45 \mathrm{E}-13$ \\
\hline Y-91m & $3.13 \mathrm{E}-16$ \\
\hline Y-92 & $4.85 \mathrm{E}-15$ \\
\hline Y-93 & $1.16 \mathrm{E}-14$ \\
\hline Y-94 & $7.65 \mathrm{E}-16$ \\
\hline Y-95 & $4.34 \mathrm{E}-16$ \\
\hline Yb-162 & $3.84 \mathrm{E}-16$ \\
\hline Yb-166 & $2.12 \mathrm{E}-14$ \\
\hline Yb-167 & $1.91 \mathrm{E}-16$ \\
\hline Yb-169 & $8.17 \mathrm{E}-14$ \\
\hline Yb-175 & $1.99 \mathrm{E}-14$ \\
\hline Yb-177 & $1.91 \mathrm{E}-15$ \\
\hline Yb-178 & $2.07 \mathrm{E}-15$ \\
\hline $\mathrm{Zn}-62$ & $1.50 \mathrm{E}-14$ \\
\hline $\mathrm{Zn}-63$ & $1.01 \mathrm{E}-15$ \\
\hline $\mathrm{Zn}-65$ & $6.18 \mathrm{E}-14$ \\
\hline $\mathrm{Zn}-69$ & $7.73 \mathrm{E}-16$ \\
\hline $\mathrm{Zn}-69 \mathrm{~m}$ & $7.33 \mathrm{E}-15$ \\
\hline $\mathrm{Zn}-71 \mathrm{~m}$ & $4.47 \mathrm{E}-15$ \\
\hline $\mathrm{Zn}-72$ & $3.58 \mathrm{E}-14$ \\
\hline $\mathrm{Zr}-86$ & $1.20 \mathrm{E}-14$ \\
\hline $\mathrm{Zr}-88$ & $1.00 \mathrm{E}-13$ \\
\hline Zr-89 & $1.51 \mathrm{E}-14$ \\
\hline Zr-93 & $6.90 \mathrm{E}-13$ \\
\hline Zr-95 & $1.61 \mathrm{E}-13$ \\
\hline Zr-97 & $2.71 \mathrm{E}-14$ \\
\hline
\end{tabular}




\section{Appendix C}

\section{Marking and Labeling}


This page intentionally left blank. 



\section{Appendix C - Marking and Labeling}

\section{C.1 Bar Code}

Bar codes (see Figure C-1) used on packages shall meet the following standards: ${ }^{7.6}$

- $\quad$ Code 39.

- Low- to medium density, low-density preferred.

- 1-inch high bar code not to exceed 6 inches wide.

- Human readable interpretation (HRI) $1 / 2$ inch high, printed below the bar code.

- Spacing between bar code and HRI will be $1 / 10$ of an inch.

- Minimum left and right margin (quiet zones) will be at least 1/25 inch.

- Bar codes and HRI will be stacked with a minimum separation of $1 / 2$ inch and in the following order: shipment number, container number.

- A total of two bar code labels shall be placed on each package near the top and on opposite sides. ${ }^{7.6}$ Drums shall have a total of two bar code labels, one on top of the drum lid and one on the side near the top. ${ }^{7.6}$

- Note: Exceptions to these requirements shall be verified with the RWMC operations prior to shipment.

- Labels shall be: ${ }^{7.6}$

○ Securely attached and able to withstand shipping conditions.

- Weatherproof and not deform when wet or fade in the sun.

○ Resistant to tearing, peeling, and cracking.

○ Printed with permanent indelible ink and remain legible.

A sample bar code shall be submitted to RWMC operations prior to the first shipment to ensure RWMC equipment can be used to read the bar code. ${ }^{7.6}$ 

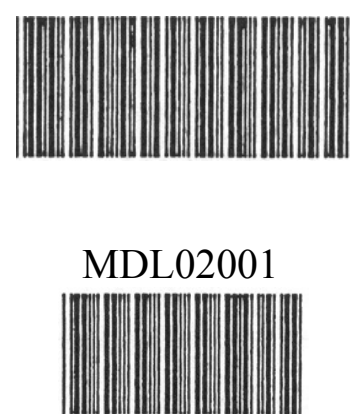

000001

\section{Figure C-1: Bar Code Label Example}

Note: Not actual size.

\section{C.2 Marking and Labeling}

Packages shall have the following markings and labels:

1. Marking and labeling as required in Title 49 CFR;

2. For additional asbestos labeling, see Section 3.1.15.

3. For additional beryllium labeling, see Section 3.1.17.

4. For additional MW labeling, see Section 3.3.6.1

5. "Package Certification Label" (PCL) (see Figure C-2), signed by the Waste Certification Official or package certifier. ${ }^{6.21 / 7.6}$ If the waste is unpackaged bulk, a signed PCL shall accompany the shipment papers. ${ }^{6.21 / 7.6}$

6. Shipment number in the following sequence: Two alpha character generatorsite-designator codes assigned by NNSA/NSO/WMP (see Section C-3); one alpha character for type of waste (L for LLW, M for MW); two numerical characters for current fiscal year; three alphanumerical characters for shipment sequence. This number shall be on the bar code. ${ }^{7.6}$ Example: MDL99001 indicates a shipment from the Mound Facility of LLW in fiscal year 1999 and the first shipment.

7. Package number shall be six characters (alpha, numeric, or combination) with no duplication within the shipment. ${ }^{7.6}$ This number shall be on the bar code. $^{7.6}$

8. Package weight in units of kilograms and pounds shall be included on the side of each waste package. ${ }^{7.6}$ The requirement can be met with a label, additions to bar code labels, or by writing the weight on the side of the waste package. 
NV-211 October 2005

USDOE

\section{PACKAGE CERTIFICATION LABEL}

This label certifies this container and its contents meet the requirements of DOT (49 CFR), EPA | (40 CFR), and NNSSWAC for transportation and disposal.

PACKAGE NUMBER:

DATE:

CERTIFIED BY (print):

CERTIFIED BY (signature):

Waste Certification Official

Alternate Waste Certification Official

Package Certifier

RWMC DESIGNATION (i.e. ONLO, ARIR):

Figure C-2: Package Certification Label 


\section{C.3 Generator Waste Stream and Shipment Codes}

\section{GENERATOR}

Aberdeen Proving Ground
Advanced MW Treatment Project
Argonne National Lab
Boeing
Brookhaven National Lab
Y-12
Duratek/ES
EnergX
GA Technologies
Idaho National Lab
Idaho Cleanup Project
LANL
LLNL
Nevada National Security Site
Nuclear Fuel Services
Oak Ridge Reservation
Paducah
Pantex
Permafix - M\&EC
Portsmouth
Princeton Plasma Physics Lab
Sandia - Albuquerque
Savannah River
Navarro- Intera
TRU Waste Processing Center
Oak Ridge National Lab
West Valley
Pan

\section{RWMC DESIGNATION \\ SITE \\ DESIGNATOR}

USAA

AMWP

ANLE

BNRC

BNLX

BWXT

DRTK

ENGX

BGAT

NEID

INEL

LANL

BCLA

LRY5

NFSI

ORTN

PGDP

AMHP

PERM

PORT

PPPL

ASLA

SVRS

LITN

FWOR

ORNL

WVDP
AP

AM

AE

BN

BR

BW

DR

EN

BG

NE

IN

LA

LL

DP

NF

OR

PD

PX

PF

PO

PL

SA

SR

IT

FW

OL

WV

Note: If generator site is not listed, develop designations and submit with first waste profiles. A database verification of uniqueness will be conducted by RWAP. 


\section{C.4 NTS Advance Shipment Notification}

\section{Nevada National Security Site \\ Advance Shipment Notification}

Shipper Name and Address:

Contact Name:

Phone/Cell/Pager:

Waste Stream Number(s):

Shipment Number:

Shipment Departure Date: Time:

Estimated Arrival Date: Time:

Carrier: Driver's Name:

Driver's License No.

State:

Tractor License No. Trailer No. Seal No.

Gross Wt. (Lbs): Type/Number of Packages: Box Drum

Bulk (cargo containers, equipment, burrito wraps, etc..) Other

DOT Proper Shipping Name(s) or Attached Bill of Lading:

Special Handling Considerations:

[ ] Asbestos [ ] Classified [ ] Mixed Waste [ ] Other:

Attachments:
[ ] PSDR
[ ] Bill of Lading
[ ] Other:

Privacy Act Statement: The information on this form is protected by the Privacy Act of 1974. The purpose of | requesting this information is to comply with the terms and conditions under which the Nevada National Security Site will accept low-level radioactive waste and mixed waste for disposal. This information will be used by the U.S. Department of Energy, National Nuclear Security Administration Nevada Site Office and its contractors. Failure to | provide this information will result in either a delay in waste receipt or waste refusal at the Nevada National Security Site.

\section{PRIVACY ACT INFORMATION}


This page intentionally left blank. 


\section{Appendix D}

\section{Package Shipment Disposal Request}


This page intentionally left blank 


\section{Appendix D - Package Shipment Disposal Request}

The activity of each nuclide in a waste package as documented on the (PSDR) shall not exceed the corresponding maximum radionuclide concentration specified on the waste profile. ${ }^{7.6}$ See Section 3.1.2 for reportable nuclides.

Shipment Number: Prepared By:

Date: Manifest No:

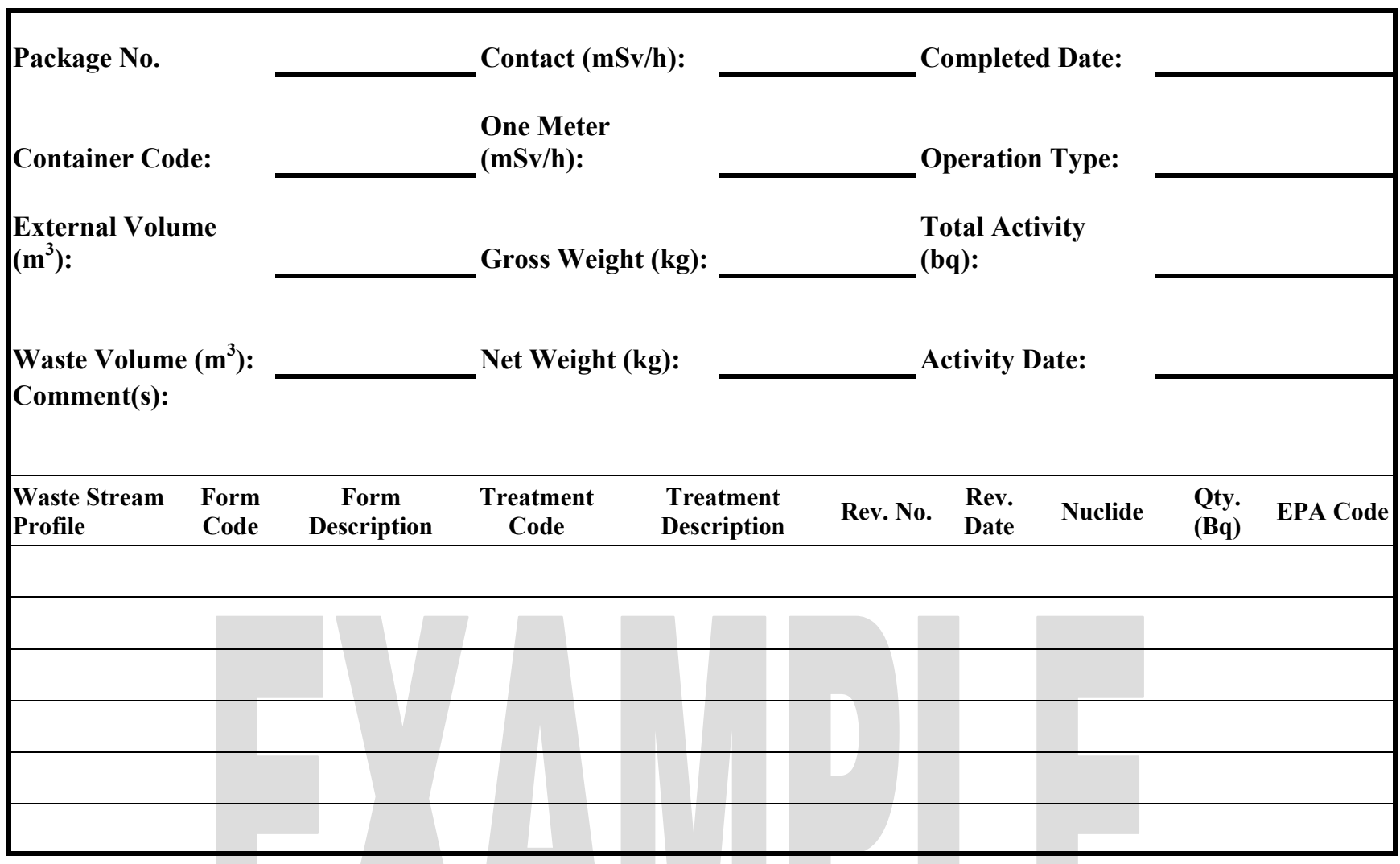

If you have any questions on completing this document, contact the operator of the NNSS at (702) 295-6811. Data entered on the form must be legible. Hand printing or typing of letters and numbers is preferred to handwritten entries. When using a decimal, it must be clearly defined.

DO NOT USE COMMAS. 


\section{PSDR Instructions}

SHIPMENT NUMBER: Consists of eight alphanumeric characters in the following sequence: two-digit generator code assigned by WMP, L (low-level) or M (mixed), last two digits of the current fiscal year (Oct. 1 - Sept. 30), and the consecutive number of shipments from the generating facility. EXAMPLE: DPL08001 represents the generator, NSTec, low-level waste, fiscal year 2008, and the first shipment to WMP for fiscal year 2008 .

MANIFEST NUMBER: Required only on LLW with PCBs and mixed waste shipments, a twelve-digit number

PACKAGE NUMBER: Six unique alphanumeric characters for each container in the shipment. See the instructions on the comment field for required information for previously rejected packages.

CONTACT:

Maximum radiation reading at the surface of the package in $\mathrm{mSv} / \mathrm{H}$ : Written in scientific notation X.XXXE \pm 00 .

COMPLETION DATE: The date, in DDMMMYYYY format (e.g., 01Jan1992), that the last waste material was placed in the package.

CONTAINER CODE: three-digit number that identifies the type of container. If your container is not listed, contact the RWMC at (702) 295-6811.

\begin{tabular}{|c|c|c|c|c|c|c|}
\hline \multirow[b]{2}{*}{ Code } & \multirow[b]{2}{*}{ Description } & \multirow[b]{2}{*}{ Length } & \multirow[b]{2}{*}{ Width } & \multirow[b]{2}{*}{ Height } & \multicolumn{2}{|c|}{ * External Volume } \\
\hline & & & & & Cubic Feet & Cubic Meters \\
\hline 100 & Miscellaneous & N/A & N/A & N/A & N/A & N/A \\
\hline 101 & 30-gallon drum & N/A & N/A & N/A & $4.99-6.99$ & $0.141-0.1979$ \\
\hline 102 & 55-gallon drum & N/A & N/A & N/A & 7.99-9.99 & $0.226-0.283$ \\
\hline 124 & 85 -gallon drum & N/A & N/A & N/A & $12.99-14.99$ & $0.368-0.424$ \\
\hline 125 & 110-gallon drum & N/A & N/A & N/A & $18.99-20.99$ & $0.537-0.594$ \\
\hline 200 & Half box & $78 "$ - 90" & $42 "-56 "$ & $18 "$ - $30^{\prime \prime}$ & $34.125-87.5$ & $0.9663-2.4777$ \\
\hline 201 & Wooden half box & $78 "$ - 90" & $42 "-56 "$ & $18 "$ - 30" & $34.125-87.5$ & $0.9663-2.4777$ \\
\hline 210 & Full box & 78" - 90" & $42 "$ - 56" & $42 "$ - 56" & $79.625-163.33$ & $2.2547-4.6250$ \\
\hline 211 & Wooden full box & $78 "$ - 90" & $42 "-56 "$ & $42 "-56 "$ & $79.625-163.33$ & $2.2547-4.6250$ \\
\hline 220 & Cargo Container & 234"-246" & $90 "-102 "$ & $90 "-102 "$ & $1,096.875-1,481.125$ & $31.060-41.940$ \\
\hline 230 & Supersack & N/A & N/A & N/A & N/A & N/A \\
\hline 240 & Burrito W rap & N/A & N/A & N/A & N/A & N/A \\
\hline 250 & Concrete Monolith & N/A & N/A & N/A & 149.734-199.987 & $4.24-5.663$ \\
\hline
\end{tabular}

1 METER:

Maximum radiation reading at 1 meter in $\mathrm{mSv} / \mathrm{h}$ : Written in scientific notation $\mathrm{X} . \mathrm{XXXE} \pm 00$.

OPERATION TYPE: $\quad$ B for burial, or R for retrievable. 
EXTERNAL VOLUME: Total volume displaced by the container in cubic meters. Refer to CONTAINER CODE. Written in scientific notation X.XXXE \pm 00 .

GROSS WEIGHT:

TOTAL ACTIVITY:

WASTE VOLUME:

NET WEIGHT:

ACTIVITY DATE:

COMMENT:

WASTE STREAM

PROFILE:

WASTE FORM CODE:

020 - Charcoal

021 - Incinerator Ash

022 - Soil

023 - Gas

024 - Oil

025 - Aqueous Liquid

026 - Filter Media

027 - Mechanical Filter

028 - EPA Hazardous
Total weight of container including waste and solidification or absorbent media in kilograms. Written in scientific notation $\mathrm{X} . \mathrm{XXXE} \pm 00$.

Total Becquerels; shall equal the sum of becquerels for each nuclide reported. Written in scientific notation X.XXXE \pm 00 .

Actual volume of waste material in package in cubic meters. Written in scientific notation X.XXXE+00.

Total weight of waste and solidification or absorbent media, excluding container, in kilograms. Written in scientific notation X.XXXE \pm 00 .

The date in DDMMMYYYY format (e.g., 01Jan1992), that the activity of the package was determined.

A twenty-seven (27) alphanumeric character field. If the package was rejected from NNSS, returned to the generator and will be reshipped to the NNSS, the original rejected package number (parent) shall be entered in parentheses. All packages generated from the repackaging of rejected waste (progeny) shall have the original rejected package number (parent) entered in parentheses in the comment section. ${ }^{7.5}$

Waste Stream Identification or profile number. Thirteen alphanumeric characters. First four characters will be the RWMC designation. Next nine alphanumeric characters will be assigned by the generator. EXAMPLE: LRY5000000001 represents waste from the NNSS.

Enter the appropriate three-digit waste form code, exactly as shown below, that categorizes the waste in the package.

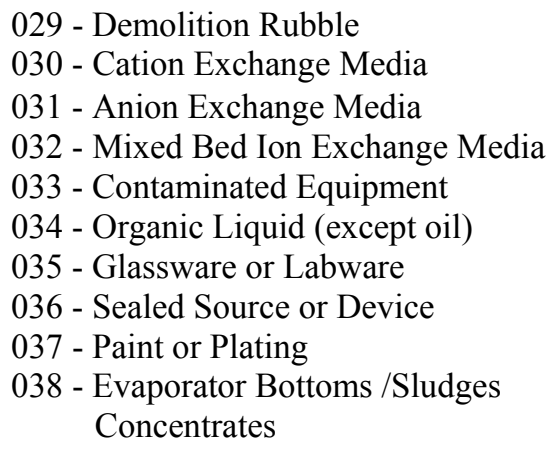

029 - Demolition Rubble

030 - Cation Exchange Media

031 - Anion Exchange Media

032 - Mixed Bed Ion Exchange Media

033 - Contaminated Equipment

034 - Organic Liquid (except oil)

035 - Glassware or Labware

036 - Sealed Source or Device

037 - Paint or Plating

038 - Evaporator Bottoms /Sludges

Concentrates

039 - Compactable Trash

040 - Non-Compactable Trash

041 - Animal Carcasses

042 - Biological Material (except animal carcasses)

043 - Activated Material (except activated metal)

044 - Activated Metal

045 - Other (Describe) 
WASTE TREATMENT CODES: Enter the appropriate three-digit treatment code, exactly as shown below, that categorizes the treatment process used on the containerized waste.

\section{$\underline{\text { Sorption }}$}

060 - Speedi Dri

061 - Celetom

062 - Floor Dry/Superfine

063 - HiDri

064 - Safe T Sorb

065 - Safe N Dry

066 - Florco

067 - Florco X

068 - Solid A Sorb

069 - Chemsil 30

070 - Chemsil 50
071 - Chemsil3030

072 - Dicaperl HP200

073 - Dicaperl HP500

074 - Zonolite Gd4

075 - Petroset

076 - Petroset II

077 - Aquaset

078 - Aquaset II

079 - Other (Describe)

080 - Quicksolid

\section{Solidification}

$\begin{array}{ll}090 \text { - } & \text { Cement } \\ 091 \text { - } & \text { Concrete Encapsulation } \\ 092 \text { - } & \text { Bitumen } \\ 093 \text { - } & \text { Vinyl Toluene } \\ 094 \text { - } & \text { Vinyl Ester Styrene } \\ 095 \text { - } & \text { Other (Describe) } \\ 100 \text { - } & \text { No Sorption or Solidification }\end{array}$

Mixed Waste

101 - AMLGM

102 - CARBN

103 - CHOXD

104 - CHRED

105 - CMBST

106 - DEACT

107 - MACRO

108 - STABL

109 - Other (Provide LDR Specified Treatment Technology Code)

110 - Meets Concentration Based LDR standards

REVISION: $\quad$ WP Revision number found in Section B.1 of the approved profile will be a two-digit number.

REVISION DATE: WP Date found in Section B.1 of the approved profile: in DDMMMYYYY format (e.g., 01Jan1992).

NUCLIDE: $\quad$ Valid nuclide description will be reported in the following format: Elemental symbol as shown on the periodic table followed by a dash (-) and then atomic mass units (e.g., Cs-137, Pu-239). Attach additional sheet(s), as needed.

QUANTITY: $\quad$ The quantity of the nuclide present in the container in Becquerels. The sum of each nuclide reported shall not exceed the total activity reported for the total package. Written in scientific notation X.XXXE \pm 00 .

EPA CODE: $\quad$ Mixed waste containers only, enter the four-digit EPA Hazardous Waste Code Number associated with the waste package. Enter "STHW" if the container is mixed waste with a state hazardous waste number and not a federal EPA Hazardous Waste Number. 


\section{Appendix E}

\section{Radiological Waste Characterization and \\ Reporting Requirements}


This page intentionally left blank. 


\section{Appendix E - Radiological Waste Characterization and Reporting Requirements}

\section{E.1 Radionuclide Reporting}

Reportable radionuclides shall be reported on the Waste Profile (WP) and Package Shipment Disposal Request (PSDR). ${ }^{6.18 / 7.5}$ Activity concentrations reported on the WP are applied at the waste stream level; activity concentrations reported on the PSDR are applied at the waste package level. Radionuclides reported on the PSDR shall be identified on the WP ${ }^{7.5}$ (See Appendix D for example of the PSDR). Determination of activity concentrations reported on the waste profile (Sections D.5 and D.6) and the PSDR shall be documented and available for review. Verification of calculations used to determine the radionuclide concentrations (data results) shall be conducted and documented. Waste packages exceeding the activity concentration upper limit will not be accepted without approval of a revised waste profile; waste concentrations less than the lower limit will be accepted without prior approval.

\section{A. Reportable Radionuclides}

Radionuclides known or reasonably expected to be present in a waste stream shall be reported as follows: $:^{6.7 / 6.16 / 6.18}$

1. The activity concentration of the radionuclides in the final waste form exceeds 1 percent of the Action Level (Table E-1). ${ }^{6.7 / 7.9}$ These radionuclides require rigorous waste characterization and shall be reported on the PSDR and the WP. ${ }^{7.5}$

2. Radionuclides that are alpha-emitting and transuranic with a half-life greater than 20 years that exceed $10 \mathrm{pCi} / \mathrm{g}$ shall be reported on the WP. ${ }^{7.5}$ The waste mass shall be determined as described in Section E.4. ${ }^{7.5}$ Transuranic waste radionuclides with concentrations that exceed $1 \mathrm{nCi} / \mathrm{g}$ require rigorous waste characterization methods and shall be reported on the PSDR and the WP. ${ }^{7.5}$

3. Activity concentrations in the final waste form that exceed 1 percent of the total activity concentration shall be reported on the PSDR and the WP. ${ }^{7.5}$ The total activity concentration shall include the activity of all radionuclides, except for those that are exempt from the reporting requirements as specified. ${ }^{6.7 / 7.9}$ For these radionuclides and for those present at a level less than the detection limit of industry-accepted characterization methods, Process Knowledge (PK) should be sufficient for characterization. 
Table E-1: Radionuclide Action Levels for Waste Characterization and Reporting

\begin{tabular}{|c|c|c|c|}
\hline Nuclide & $\begin{array}{c}\text { Action Level } \\
\left(\mathrm{Bq} \mathrm{m}^{-3}\right)\end{array}$ & Nuclide & $\begin{array}{c}\text { Action Level } \\
\left(\mathrm{Bq} \mathrm{m}^{-3}\right)\end{array}$ \\
\hline${ }^{3} \mathrm{H}$ & $6.2 \mathrm{E}+11$ & ${ }^{210} \mathrm{~Pb}$ & $3.5 \mathrm{E}+11$ \\
\hline${ }^{14} \mathrm{C}$ & $5.4 \mathrm{E}+15$ & ${ }^{226} \mathrm{Ra}$ & $2.1 \mathrm{E}+07$ \\
\hline${ }^{26} \mathrm{Al}$ & $9.7 \mathrm{E}+07$ & ${ }^{228} \mathrm{Ra}$ & $1.7 \mathrm{E}+12$ \\
\hline${ }^{36} \mathrm{Cl}$ & $1.9 \mathrm{E}+08$ & ${ }^{227} \mathrm{Ac}$ & $1.7 \mathrm{E}+11$ \\
\hline${ }^{39} \mathrm{Ar}$ & $9.9 \mathrm{E}+20$ & $228 \mathrm{Th}$ & $4.3 \mathrm{E}+13$ \\
\hline${ }^{40} \mathrm{~K}$ & $9.4 \mathrm{E}+10$ & 229Th & $2.8 \mathrm{E}+10$ \\
\hline${ }^{41} \mathrm{Ca}$ & $2.8 \mathrm{E}+12$ & $230 \mathrm{Th}$ & $6.0 \mathrm{E}+07$ \\
\hline${ }^{59} \mathrm{Ni}$ & $1.7 \mathrm{E}+14$ & ${ }^{232} \mathrm{Th}$ & $8.1 \mathrm{E}+09$ \\
\hline${ }^{63} \mathrm{Ni}$ & $3.2 \mathrm{E}+14$ & ${ }^{231} \mathrm{~Pa}$ & $1.0 \mathrm{E}+10$ \\
\hline${ }^{60} \mathrm{Co}$ & $1.6 \mathrm{E}+12$ & ${ }^{232} \mathrm{U}$ & $4.3 \mathrm{E}+10$ \\
\hline${ }^{85} \mathrm{Kr}$ & $2.0 \mathrm{E}+20$ & ${ }^{233} \mathrm{U}$ & $8.2 \mathrm{E}+10$ \\
\hline${ }^{90} \mathrm{Sr}$ & $4.3 \mathrm{E}+11$ & ${ }^{234} \mathrm{U}$ & $1.3 \mathrm{E}+10$ \\
\hline${ }^{93} \mathrm{Zr}$ & $1.1 \mathrm{E}+14$ & ${ }^{235} \mathrm{U}$ & $1.1 \mathrm{E}+11$ \\
\hline${ }^{93 \mathrm{~m}} \mathrm{Nb}$ & $4.6 \mathrm{E}+15$ & ${ }^{236} \mathrm{U}$ & $2.8 \mathrm{E}+11$ \\
\hline${ }^{94} \mathrm{Nb}$ & $1.2 \mathrm{E}+10$ & ${ }^{238} \mathrm{U}$ & $3.5 \mathrm{E}+11$ \\
\hline${ }^{99} \mathrm{Tc}$ & $3.2 \mathrm{E}+09$ & ${ }^{237} \mathrm{~Np}$ & $3.4 \mathrm{E}+10$ \\
\hline${ }^{107} \mathrm{Pd}$ & $2.9 \mathrm{E}+14$ & ${ }^{238} \mathrm{Pu}$ & $1.8 \mathrm{E}+12$ \\
\hline${ }^{113 \mathrm{~m}} \mathrm{Cd}$ & $6.2 \mathrm{E}+12$ & ${ }^{239} \mathrm{Pu}$ & $5.1 \mathrm{E}+11$ \\
\hline${ }^{121 \mathrm{~m}} \mathrm{Sn}$ & $2.1 \mathrm{E}+14$ & ${ }^{240} \mathrm{Pu}$ & $5.2 \mathrm{E}+11$ \\
\hline${ }^{126} \mathrm{Sn}$ & $1.1 \mathrm{E}+10$ & ${ }^{241} \mathrm{Pu}$ & $5.8 \mathrm{E}+12$ \\
\hline${ }^{129} \mathrm{I}$ & $3.4 \mathrm{E}+09$ & ${ }^{242} \mathrm{Pu}$ & $3.7 \mathrm{E}+11$ \\
\hline${ }^{133} \mathrm{Ba}$ & $5.4 \mathrm{E}+12$ & ${ }^{244} \mathrm{Pu}$ & $4.8 \mathrm{E}+10$ \\
\hline${ }^{135} \mathrm{Cs}$ & $2.8 \mathrm{E}+12$ & ${ }^{241} \mathrm{Am}$ & $1.7 \mathrm{E}+11$ \\
\hline${ }^{137} \mathrm{Cs}$ & $2.5 \mathrm{E}+11$ & ${ }^{243} \mathrm{Am}$ & $5.8 \mathrm{E}+10$ \\
\hline${ }^{150} \mathrm{Eu}$ & $9.4 \mathrm{E}+10$ & ${ }^{243} \mathrm{Cm}$ & $8.3 \mathrm{E}+11$ \\
\hline${ }^{152} \mathrm{Eu}$ & $4.7 \mathrm{E}+11$ & ${ }^{244} \mathrm{Cm}$ & $3.4 \mathrm{E}+12$ \\
\hline${ }^{154} \mathrm{Eu}$ & $1.7 \mathrm{E}+12$ & ${ }^{245} \mathrm{Cm}$ & $4.6 \mathrm{E}+10$ \\
\hline${ }^{151} \mathrm{Sm}$ & $2.4 \mathrm{E}+15$ & ${ }^{246} \mathrm{Cm}$ & $9.2 \mathrm{E}+10$ \\
\hline${ }^{166 \mathrm{~m}} \mathrm{Ho}$ & $1.2 \mathrm{E}+10$ & ${ }^{248} \mathrm{Cm}$ & $2.9 \mathrm{E}+10$ \\
\hline${ }^{207} \mathrm{Bi}$ & $1.1 \mathrm{E}+11$ & ${ }^{250} \mathrm{Cf}$ & $1.5 \mathrm{E}+12$ \\
\hline
\end{tabular}




\section{B. Exempt Radionuclides}

Radionuclides meeting any of the following criteria are exempt from the reporting requirements:

1. Any radionuclide, as listed in Table E-2, that will reach a state of transient or secular equilibrium with a parent radionuclide within the operational period of the disposal site.

2. Any radionuclide occurring at activity concentrations not exceeding background ranges for the region in which it was generated and material of interest.

\section{Table E-2: Exempt Radionuclides}

\begin{tabular}{|l|}
\hline${ }^{90} \mathrm{Y},{ }^{93} \mathrm{Nb},{ }^{126 \mathrm{~m}} \mathrm{Sb},{ }^{126} \mathrm{Sb},{ }^{137 \mathrm{~m}} \mathrm{Ba}$ \\
\hline${ }^{233} \mathrm{~Pa},{ }^{225} \mathrm{Ra},{ }^{225} \mathrm{Ac},{ }^{221} \mathrm{Fr},{ }^{217} \mathrm{At},{ }^{213} \mathrm{Bi},{ }^{213} \mathrm{Po},{ }^{209} \mathrm{Tl},{ }^{209} \mathrm{~Pb}$ \\
\hline${ }^{239} \mathrm{~Np},{ }^{231} \mathrm{Th},{ }^{227} \mathrm{Th},{ }^{223} \mathrm{Fr},{ }^{223} \mathrm{Ra},{ }^{219} \mathrm{Rn},{ }^{215} \mathrm{Po},{ }^{211} \mathrm{~Pb},{ }^{211} \mathrm{Bi},{ }^{211} \mathrm{Po},{ }^{207} \mathrm{Tl}$ \\
\hline${ }^{234} \mathrm{Th},{ }^{234 \mathrm{~m}} \mathrm{~Pa},{ }^{234} \mathrm{~Pa},{ }^{222} \mathrm{Rn},{ }^{218} \mathrm{Po},{ }^{214} \mathrm{~Pb},{ }^{214} \mathrm{Bi},{ }^{214} \mathrm{Po},{ }^{210} \mathrm{Bi},{ }^{210} \mathrm{Po}$ \\
\hline${ }^{240} \mathrm{U},{ }^{240 \mathrm{~m}} \mathrm{~Np},{ }^{240} \mathrm{~Np},{ }^{228} \mathrm{Ra},{ }^{228} \mathrm{Ac},{ }^{228} \mathrm{Th},{ }^{224} \mathrm{Ra},{ }^{220} \mathrm{Rn},{ }^{216} \mathrm{Po},{ }^{212} \mathrm{~Pb},{ }^{212} \mathrm{Bi},{ }^{212} \mathrm{Po},{ }^{208} \mathrm{Tl}$ \\
\hline
\end{tabular}

Note: The progeny radionuclides listed are exempt from reporting requirements when a parent radionuclide is present.

\section{E.2 Reserved to maintain section numbering.}

\section{E.3 Radiological Characterization Methods}

Waste characterization methods are described below and are not intended to be allinclusive. These methods can be used individually or in combination. The NNSA/NSO will use a graded approach in its acceptance of waste characterization methods. Generators are encouraged to develop innovative waste characterization plans designed for the specific conditions at their facilities.

The acceptability of a generator's waste characterization plan will be based on a determination that the level of effort is appropriate, given the potential of the waste stream to exceed the waste concentration action levels (Table E-1) and the physical limitations of the waste stream. Physical limitations may include waste matrices that cannot be representatively sampled because of unreasonable radiation exposure. Generators are expected to identify, based on knowledge of their processes and facility, those radionuclides with a reasonable probability of exceeding 1 percent of the waste concentration action level. Waste streams or waste packages reasonably expected to exceed 1 percent of the waste concentration action levels (Table E-1) will require the greatest level of characterization and verification. 


\section{A. Materials Controls and Accountability (MC\&A)}

MC\&A records are data developed from a mass balance of material entering and exiting a process. MC\&A data can be used to estimate the activity concentration of waste streams. This method is expected to be most useful for generators possessing limited numbers of nuclides, such as special nuclear materials, in known activity concentrations.

\section{B. Gross Radiation Measurements}

Scaling factors can be developed that relate gross radiation measurements to the activity concentration of a waste stream. Generators using gross radiation measurements shall ensure that measurements correlate with activity concentration on a consistent basis. ${ }^{7.8}$ Radionuclide distributions in the waste stream shall be initially determined and periodically verified through direct measurements or sampling and analysis. ${ }^{7.8}$ Generators shall document all methods used to develop scaling factors which relate gross radiation measurements to the activity concentration. ${ }^{7.8}$ When developing scaling factors, generators shall consider the waste package and detector geometry, shielding and attenuation effects, self-absorption, and the energy spectra and decay schemes of radionuclides in the waste. ${ }^{7.8}$

\section{Direct Measurement of Specific Radionuclides}

Direct measurement of radionuclides may include nondestructive analysis of waste packages. In using this method, individual radionuclides are measured.

\section{Sampling and Analysis}

Radiological characterization using sampling and analysis, including swipes taken for characterization, shall be controlled. ${ }^{6.24 / 1.3}$

\section{E. Process Knowledge}

Process knowledge will often be sufficient for characterization of radionuclides not having action levels or occurring at concentrations less than 1 percent of the action level. This method involves determining the radionuclide content of the waste through knowledge and control of the source of the waste.

\section{E.4 Determination of Waste Volume}

Waste activity concentration shall be determined based on the volume of the final waste form as offered for disposal. ${ }^{7.5}$ Measurement or analysis of samples may be performed prior to final processing if the measured activity concentration can be related to the final activity concentration. The volume of the waste can usually be taken as the internal volume of the container if the radionuclides are reasonably homogeneously distributed throughout the waste and the waste fills at least 90 percent of the waste container. When 
these conditions are not met (for example when the package contains significant void space or contains irregularly shaped equipment or components) the volume shall be taken as the volume occupied by the waste in the container. ${ }^{6.19}$ The activity concentration of transuranic radionuclides in units of $\mathrm{nCi} / \mathrm{g}$ shall be based on the mass of the contents of a single waste container, excluding the mass of the container and any shielding present. ${ }^{7.6}$

\section{E.5 Examples of Waste Characterization Documentation}

A. PK documentation:

Historical analytical data, literature searches, living memory, historic records, MC\&A records, mass balance documentation, production specifications, certificates of traceability, plans and drawings, signed statements of living memory, system descriptions, work and operating procedures which generated waste, and Material Safety Data Sheets.

B. Evaluation of PK and historical data

C. Independent review of program documents: May be in the form of a sign-off page within the approved document.

D. Reviewed and approved procedures:

Direct measurement and/or survey processes, surface area estimations (when surface area of waste material is utilized in radiological characterization calculations), and ratio/scaling factor information (approach to ratio/scaling factor development, application of ratios/scaling factors, justification for use of ratios/scaling factors, supporting calculations, operating procedures for assay equipment).

E. Evaluated Data, Validated Data, Sampling and Analysis Plan, Scope of Work, and Laboratory Acquisition Document.

\section{E.6 Radiological Characterization Flow Diagram Overview}

Figure E-1, the radiological characterization flow diagram, illustrates the approach that should be used to obtain adequate radiological characterization. The approach allows for the utilization of generally accepted radiological characterization methodologies and documentation. Radiological characterization documentation requirements are outlined on the radiological characterization flow diagram. 


\section{Figure E-1: Radiological Characterization Flow Diagram}

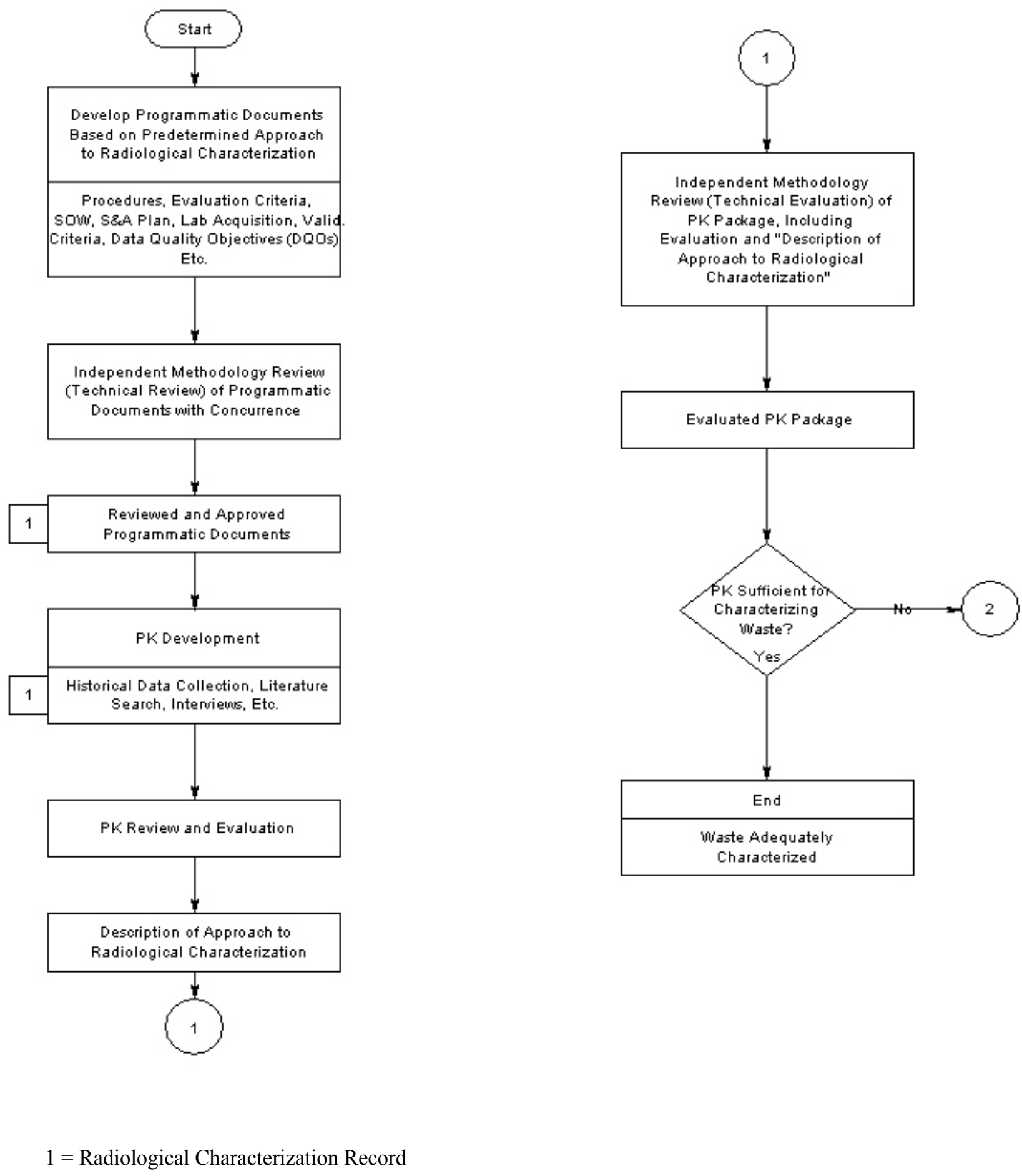




\section{Figure E-1 (continued)}

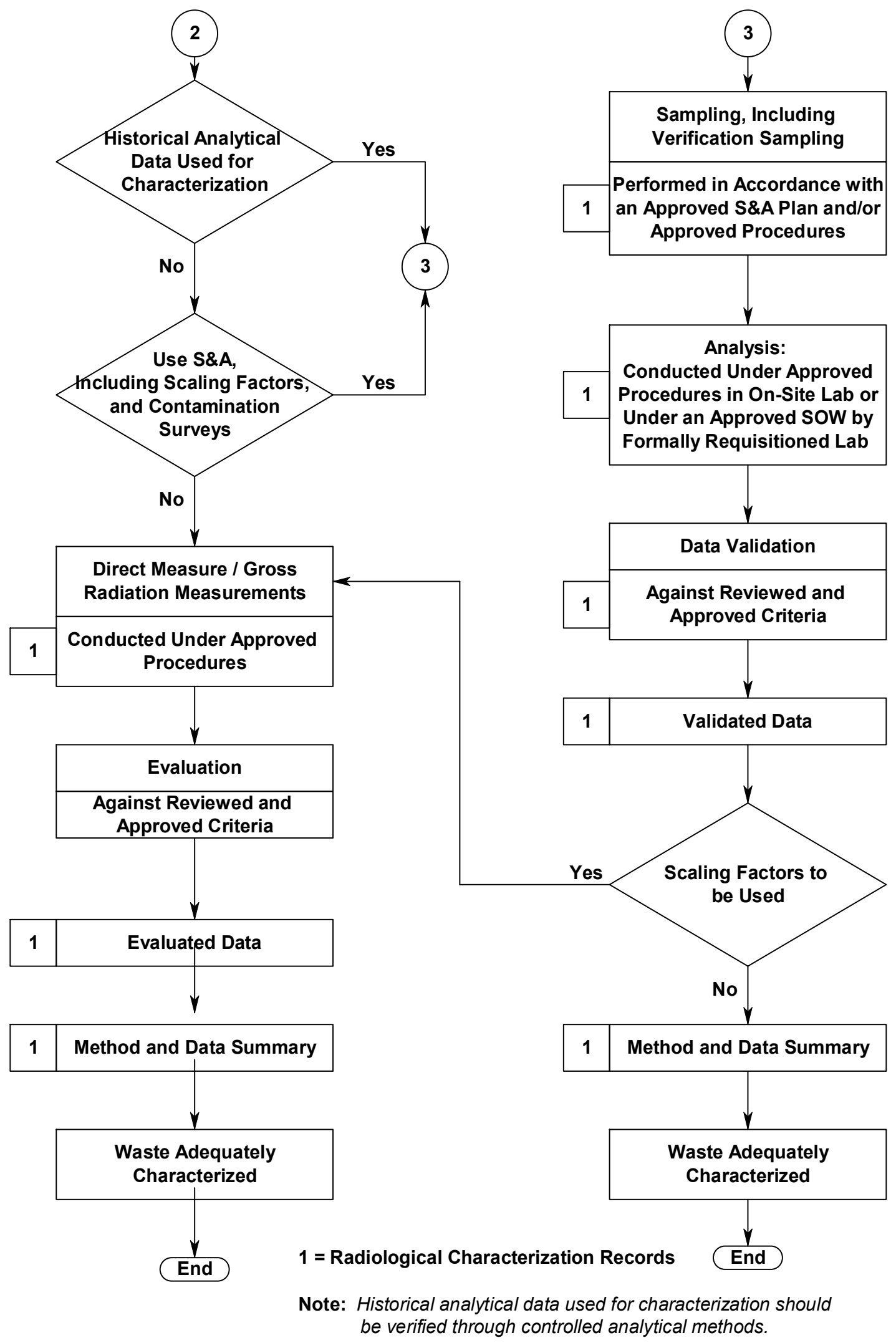




\section{E.7 Fissile Material Limits}

The quantity of fissile material in a waste package acceptable for disposal shall be demonstrated to meet any of the following:

1. Meets criteria specified in 49 CFR 173.453, Fissile materials - exceptions.

2. Does not exceed 350 grams of ${ }^{235} U$ FGE per package nor exceed $2 \mathrm{~g}$ of ${ }^{235} \mathrm{U}$ FGE per kilogram of waste (mass of the package is not included in the mass of the waste) (graphite and beryllium shall not exceed $1 \%$ by mass of the waste). FGE is determined by completing Table E.3. Both limits shall not be exceeded. ${ }^{7.15}$ This criteria applies to 55-gallon metal drums or larger containers (i.e., 85-gallon drums, $4 \mathrm{X} 4 \mathrm{X} 6 \mathrm{ft}$. metal boxes) and is not applicable to drums $<55$-gallon or soft sided, wood, or plastic containers.

3. Does not exceed the limits and the waste package meets the conditions as specified in Table E.4. ${ }^{7.14 / 7.16}$

4. Does not exceed the limits and the waste package meets the conditions as specified in Tables E.5 and E.6. ${ }^{7.17}$

Note: Waste containing uranium with enrichment less than 0.90 percent ${ }^{235} \mathrm{U}$ by weight and those nuclides listed in Table E. 3 such that their FGE is 1 percent or less of the tabulated grams of ${ }^{235} \mathrm{U}$ do not provide a fissile material concern.

If the waste does not comply with any of above, then a waste specific nuclear criticality safety evaluation (NCSE) may be necessary for acceptance of the waste. Please contact the RWAP Task Manager for further information on the criteria for performing a NCSE.

If the waste stream contains enriched uranium $\left({ }^{235} \mathrm{U}\right.$ weight percent $\left.\geq 0.90\right),{ }^{233} \mathrm{U},{ }^{239} \mathrm{Pu}$, ${ }^{241} \mathrm{Pu},{ }^{242 \mathrm{~m}} \mathrm{Am},{ }^{243} \mathrm{Cm},{ }^{245} \mathrm{Cm},{ }^{247} \mathrm{Cm},{ }^{249} \mathrm{Cf}$, or ${ }^{251} \mathrm{Cf}$, the ${ }^{235} \mathrm{U}$ FGE and ${ }^{235} \mathrm{U}$ effective enrichment is required to be reported with the profile by completing Table E. 3 for each enrichment range. The waste shall not exceed the total FGE as specified for the effective enrichment. 
Table E-3: Calculation of ${ }^{235} \mathbf{U}$ Fissile Gram Equivalent and Effective ${ }^{235} \mathbf{U}$ Enrichment for LLW Packages

\begin{tabular}{|c|c|c|c|c|c|c|c|c|}
\hline (A) & $\begin{array}{c}\text { High } \\
\text { Activity } \\
\text { Conc. } \\
\text { (Bq/m3) } \\
\text { (B) } \\
\end{array}$ & $\begin{array}{c}\begin{array}{c}\text { Volume } \\
\text { of }\end{array} \\
\text { Package } \\
\text { (m3) } \\
\text { (C) } \\
\end{array}$ & $\begin{array}{c}\begin{array}{c}\text { Activity } \\
\text { (Bq) }\end{array} \\
\text { (D) } \\
\end{array}$ & $\begin{array}{c}\text { Specific } \\
\text { Activity } \\
\text { (Bq/g) } \\
\text { (E) } \\
\end{array}$ & $\begin{array}{c}\begin{array}{c}\text { Mass of } \\
\text { Nuclide } \\
\text { (g) }\end{array} \\
(\mathrm{D} / \mathrm{E}=\mathrm{F}) \\
\end{array}$ & $\begin{array}{c}{ }^{235} \mathbf{U} \\
\text { FGE } \\
\text { Factors } \\
(\mathbf{G}) \\
\end{array}$ & $\begin{array}{l}{ }^{235} \text { U FGE } \\
\left(F^{*} \mathbf{G}=\mathbf{H}\right)\end{array}$ & $\begin{array}{c}\text { If FGE is }> \\
1 \% \text { of }{ }^{235} \mathrm{U} \\
\text { Mass, then } \\
\text { include } \\
\text { (I) } \\
\end{array}$ \\
\hline${ }^{233} \mathrm{U}$ & & & & $3.6 \mathrm{E}+08$ & & $1.4 \mathrm{E}+00$ & & \\
\hline${ }^{235} \mathrm{U}$ & & & & $8.1 \mathrm{E}+04$ & & $1.0 \mathrm{E}+00$ & & \\
\hline${ }^{239} \mathrm{Pu}$ & & & & $2.3 \mathrm{E}+09$ & & $1.6 \mathrm{E}+00$ & & \\
\hline${ }^{241} \mathrm{Pu}$ & & & & $3.8 \mathrm{E}+12$ & & $3.5 \mathrm{E}+00$ & & \\
\hline${ }^{242 \mathrm{~m}} \mathrm{Am}$ & & & & $3.6 \mathrm{E}+11$ & & $5.4 \mathrm{E}+01$ & & \\
\hline${ }^{243} \mathrm{Cm}$ & & & & $1.9 \mathrm{E}+12$ & & $7.8 \mathrm{E}+00$ & & \\
\hline${ }^{245} \mathrm{Cm}$ & & & & $6.4 \mathrm{E}+09$ & & $2.3 \mathrm{E}+01$ & & \\
\hline${ }^{247} \mathrm{Cm}$ & & & & $3.5 \mathrm{E}+06$ & & $7.8 \mathrm{E}-01$ & & \\
\hline${ }^{249} \mathrm{Cf}$ & & & & $1.5 \mathrm{E}+11$ & & $7.0 \mathrm{E}+01$ & & \\
\hline${ }^{251} \mathrm{Cf}$ & & & & $5.9 \mathrm{E}+10$ & & $1.4 \mathrm{E}+02$ & & \\
\hline \multicolumn{7}{|c|}{\begin{tabular}{lc} 
Effective $^{235} \mathrm{U}=$ & Total $^{235} \mathbf{U}$ FGE \\
\cline { 2 - 2 } Enrichment & Total U
\end{tabular}} & $\begin{array}{l}\text { TOTAL } \\
{ }^{235} \text { U FGE }\end{array}$ & \\
\hline \multicolumn{7}{|c|}{ Effective ${ }^{235}$ U Enrichment = } & & \\
\hline
\end{tabular}

Instructions for completing Table E.3:

1. Multiply high activity range of the waste stream $\left(\mathrm{Bq} / \mathrm{m}^{3}\right)$ by volume of waste to determine the maximum activity that could be present in a waste package for the nuclides listed above, resulting in $\mathrm{Bq}$ (Column $\mathrm{D}$ ). For ${ }^{235} \mathrm{U}$, the activity is required to be included only if the ${ }^{235} \mathrm{U}$ enrichment is equal to or greater than 0.90 percent by weight of total $\mathrm{U}$.

2. Divide activity $(\mathrm{Bq})($ Column $\mathrm{D})$ by the specific activity of the nuclide $(\mathrm{Bq} / \mathrm{g})($ Column $\mathrm{E})$ to determine the mass of the nuclide (Column F).

3. Multiply the mass (g) (Column F) of each nuclide by the ${ }^{235} \mathrm{U}$ FGE factor (Column G) to determine FGE (Column H).

4. If the FGE value is greater than 1 percent of the ${ }^{235} \mathrm{U}$ mass, then include in Column I to determine the total ${ }^{235} \mathrm{U}$ FGE for a waste package.

5. Effective ${ }^{235} \mathrm{U}$ enrichment (weight \%) is calculated by dividing the total ${ }^{235} \mathrm{U}$ FGE by the total mass (g) of uranium and multiplying by 100 . 
Table E-4: Allowable Package Fissile Loadings for Various Package Steel Weights

\begin{tabular}{|c|c|c|c|c|}
\hline \multirow{2}{*}{$\begin{array}{l}\quad{ }^{235} \mathrm{U} \\
\text { Enrichment } \\
\text { Weight \% }\end{array}$} & \multicolumn{4}{|c|}{$\begin{array}{l}\text { Refer to below instructions when using this table. } \\
\text { Maximum Grams of }{ }^{235} \mathrm{U} \text { per Package }\end{array}$} \\
\hline & $\begin{array}{c}35 \text { Pounds }(16 \mathrm{~kg}) \\
\text { Steel }\end{array}$ & $\begin{array}{l}50 \text { Pounds }(23 \mathrm{~kg}) \\
\text { Steel }\end{array}$ & $\begin{array}{c}70 \text { Pounds }(32 \mathrm{~kg}) \\
\text { Steel }\end{array}$ & $\begin{array}{c}105 \text { Pounds }(48 \mathrm{~kg}) \\
\text { Steel }\end{array}$ \\
\hline $80-100$ & 54 & 66 & 82 & 103 \\
\hline $60-80$ & 55 & 67 & 83 & 105 \\
\hline $40-60$ & 56 & 68 & 85 & 107 \\
\hline $20-40$ & 60 & 73 & 90 & 110 \\
\hline $15-20$ & 65 & 78 & 95 & 120 \\
\hline $10-15$ & 70 & 83 & 100 & 130 \\
\hline $8-10$ & 75 & 90 & 110 & 140 \\
\hline $7-8$ & 80 & 97 & 120 & 150 \\
\hline $6-7$ & 85 & 104 & 130 & 160 \\
\hline $5-6$ & 90 & 109 & 135 & 170 \\
\hline $4.5-5$ & 100 & 121 & 150 & 190 \\
\hline $4-4.5$ & 105 & 129 & 160 & 200 \\
\hline $3.5-4.0$ & 110 & 136 & 170 & 210 \\
\hline $3.0-3.5$ & 120 & 146 & 180 & 230 \\
\hline $2.5-3.0$ & 140 & 170 & 210 & 270 \\
\hline $2.0-2.5$ & 170 & 209 & 260 & 330 \\
\hline $1.9-2.0$ & 220 & 271 & 340 & 440 \\
\hline $1.8-1.9$ & 240 & 296 & 370 & 480 \\
\hline $1.7-1.8$ & 260 & 324 & 410 & 530 \\
\hline $1.6-1.7$ & 290 & 363 & 460 & 590 \\
\hline $1.5-1.6$ & 330 & 411 & 520 & 670 \\
\hline $1.4-1.5$ & 380 & 479 & 610 & 790 \\
\hline $1.3-1.4$ & 460 & 580 & 740 & 960 \\
\hline $1.25-1.3$ & 580 & 739 & 950 & 1250 \\
\hline $1.20-1.25$ & 670 & 854 & 1100 & 1460 \\
\hline $1.15-1.20$ & 780 & 1003 & 1300 & 1700 \\
\hline $1.10-1.15$ & 950 & 1220 & 1580 & 2100 \\
\hline $1.07-1.10$ & 1150 & 1514 & 2000 & 2700 \\
\hline $1.04-1.07$ & 1400 & 1829 & 2400 & 3200 \\
\hline $1.02-1.04$ & 1700 & 2214 & 2900 & 4000 \\
\hline $1.00-1.02$ & 2000 & 2643 & 3500 & 4800 \\
\hline $0.99-1.00$ & 2350 & 3143 & 4200 & 5800 \\
\hline $0.98-0.99$ & 2600 & 3500 & 4700 & 6500 \\
\hline $0.97-0.98$ & 3000 & 4029 & 5400 & 7600 \\
\hline $0.96-0.97$ & 3400 & 4600 & 6200 & 8500 \\
\hline $0.95-0.96$ & 3800 & 5171 & 7000 & 10000 \\
\hline$<0.95$ & 4400 & 5943 & 8000 & unlimited \\
\hline
\end{tabular}


Instructions for using Table E-4:

1. For LLW that has enrichment exactly at the boundary between two enrichment ranges, the larger fissile mass loading may be used.

2. Linear interpolations between steel weights are allowed. For steel weights in excess of $105 \mathrm{lb}$ (48 $\mathrm{kg}$ ), use the fissile mass for $105 \mathrm{lb}(48 \mathrm{~kg})$; do not extrapolate to a larger fissile mass.

3. Table E-4 is not acceptable for LLW containing more than 1 percent beryllium and carbon graphite by package weight.

4. For waste with nuclides found in Table E-3 of the NNSSWAC (other than ${ }^{235} \mathrm{U}$ ) such that their fissile gram equivalence (FGE) exceeds 1 percent of the grams of ${ }^{235} \mathrm{U}$ present in the waste, then these nuclides shall be accounted for. To account for these nuclides, an effective enrichment shall be calculated as: $\left({ }^{235} \mathrm{U}\right.$ grams + FGE $)$ divided by Total $U$ and multiplied by 100 percent. The effective enrichment and the sum of the total ${ }^{235} \mathrm{U}$ FGE are determined by completing Table E-3, and they are used to verify compliance with Table E-4.

5. The total weight of steel in a package may include that of all inner drums such as 10-, 15-, and 30gallon drums inside of a 55-gallon drum, and the outer drum.

6. Mixing drums in an overpack, such as commingling 15-, 30-, and 55-gallon drums in a 4 x 4 x 7 box, is acceptable as long as the individual drums comply with Table E-4 limits.

Low-level waste (LLW) packages meeting the restrictions as specified in Table E-5 and the fissile limits in Table E-6 satisfy the criticality safety criteria specified in Section 3.2.1.

Table E-5: Criticality Safety Restrictions for the Use of the Fissile Limits in Table E-6

\begin{tabular}{|c|c|}
\hline Volume of overpack, if used & $>$ nominal 55 gallons (outermost container) \\
\hline Volume of waste container & $\begin{array}{l}55 \text { gallon drum (may contain inner drums such as a 10- } \\
\text { gallon container inside a } 30 \text {-gallon drum, both within the } \\
55 \text {-gallon outer drum) }\end{array}$ \\
\hline $\begin{array}{l}\text { Space between } 55 \text {-gallon drum (waste container) } \\
\text { and inner containers }\end{array}$ & $\begin{array}{l}\text { If filled, the material shall be loose, pourable material } \\
\text { (e.g., vermiculite). }\end{array}$ \\
\hline Boron location & Boron shall be inside 55-gallon drum. \\
\hline Boron physical properties (natural) & $\approx 20$ atom $\%{ }^{10} \mathrm{~B}, \approx 80$ atom $\%{ }^{11} \mathrm{~B}$ \\
\hline $\begin{array}{l}\text { Boron weight Note: For example, } 12.9 \mathrm{~kg} \text { of } \mathrm{B} 2 \mathrm{O} 3 \\
\text { is required to have } 4 \mathrm{~kg} \text { of boron }\end{array}$ & $\begin{array}{l}\geq \text { nominal } 9 \text { pounds }(4 \mathrm{~kg}) \\
\text { Note: the form is not controlled; e.g., Boraxo, B4C, and } \\
\text { Borosilicate glass are all acceptable, but it shall be loose / } \\
\text { pourable. }\end{array}$ \\
\hline Beryllium and graphite by package weight & $\leq 1 \%$ by weight \\
\hline $\begin{array}{l}\text { Maximum hydrogen content of waste as packed } \\
\text { and as received at the NNSS. }\end{array}$ & $\begin{array}{l}\text { Hydrogen to }{ }^{235} \mathrm{U} \text { atom ratio }(\mathrm{H} / \mathrm{X}) \text { shall be less than } 50 \text {. } \\
\text { For example, this limit is equivalent to a water-to- }{ }^{235} \mathrm{U} \\
\text { mass ratio of all hydrogenous materials, such as plastics } \\
\text { and cellulose, may be assumed to be water to determine } \\
\text { an equivalent water mass. That is, } 1 \mathrm{~g} \text { plastics }=1 \mathrm{~g} \text { water. }\end{array}$ \\
\hline Packaging (drum) material and mass & No restrictions. \\
\hline 235 $\mathrm{U}$ limits per package & The values presented in Table E-6. \\
\hline
\end{tabular}


Table E-6: Maximum Grams of ${ }^{235} \mathrm{U}$ as a Function of Enrichment (Controls as specified in Table E-.5)

\begin{tabular}{|c|c|c|c|}
\hline $\begin{array}{l}{ }^{{ }^{235} \mathbf{U}} \\
\text { Enrichment } \\
\text { (Weight \%) }\end{array}$ & $\begin{array}{r}{ }^{235} \mathbf{U} \\
(\mathrm{g})\end{array}$ & $\begin{array}{l}{ }^{{ }^{\mathbf{2 3 5}} \mathbf{U}} \\
\text { Enrichment } \\
\text { (Weight \%) }\end{array}$ & $\begin{array}{r}{ }^{235} \mathbf{U} \\
(\mathrm{g})\end{array}$ \\
\hline 0.95 & 9000 & 2.50 & 1810 \\
\hline 0.96 & 8900 & 3.00 & 1650 \\
\hline 0.97 & 8800 & 3.50 & 1554 \\
\hline 0.98 & 8700 & 4.00 & 1485 \\
\hline 0.99 & 8357 & 4.50 & 1436 \\
\hline 1.00 & 7800 & 5.00 & 1400 \\
\hline 1.02 & 7195 & 6.00 & 1225 \\
\hline 1.04 & 6580 & 7.00 & 1179 \\
\hline 1.07 & 5860 & 8.00 & 1125 \\
\hline 1.10 & 5200 & 9.00 & 1072 \\
\hline 1.15 & 4400 & 10.00 & 1028 \\
\hline 1.20 & 3840 & 15.00 & 929 \\
\hline 1.25 & 3500 & 20.00 & 873 \\
\hline 1.30 & 3225 & 30.00 & 814 \\
\hline 1.40 & 2895 & 40.00 & 776 \\
\hline 1.50 & 2650 & 50.00 & 743 \\
\hline 1.60 & 2460 & 60.00 & 720 \\
\hline 1.70 & 2335 & 70.00 & 715 \\
\hline 1.80 & 2215 & 80.00 & 700 \\
\hline 1.90 & 2135 & 90.00 & 690 \\
\hline 2.00 & 2060 & 100.00 & 680 \\
\hline
\end{tabular}

Instructions for using Table E-6:

1. For waste with nuclides found in Table E-3 of the NNSSWAC (other than ${ }^{235} \mathrm{U}$ ) such that their fissile gram equivalence (FGE) exceeds 1 percent of the grams of ${ }^{235} \mathrm{U}$ present in the waste, then these nuclides shall be accounted for. To account for these nuclides, an effective enrichment shall be calculated as $\left({ }^{235} \mathrm{U}\right.$ grams + FGE) divided by Total $\mathrm{U}$ and multiplied by 100 percent. The total ${ }^{235} \mathrm{U}$ FGE and effective ${ }^{235} \mathrm{U}$ enrichment are determined by completing Table E-3 and they are used to verify compliance with Table E-6. 


\section{Appendix F}

\section{Requirements for Intermodal (Roll-Off Boxes) LLW Disposal}


This page intentionally left blank. 


\section{Appendix F - Requirements for Intermodal (Roll-off boxes) LLW Disposal}

These requirements are specific to intermodal roll-off containers that will be emptied and returned to the generator facility. Intermodals to be returned will have required shipping documents, etc. prepared and provided by the generator. RWMC personnel will ensure applicable DOT requirements are satisfied before released, but will not be responsible for completing required shipping documents. Waste contamination levels should be provided to RWMC operations personnel prior to receipt.

Intermodal (roll-offs) containers used for disposal of bulk LLW shall meet applicable NNSSWAC requirements and the following:

\section{Prohibited Waste Types:}

1. Classified waste

2. Asbestiform LLW (regulated)

3. MLLW

4. Hydrocarbon Burdened Low-Level Waste

5. PCB Waste (Except PCB Bulk Product Waste, see \#5 below.)

6. Fine particulates that could become airborne

7. Gas cylinders, fire extinguishers, aerosol cans (pressurized or not)

8. LLW Beryllium Waste (particulate)

9. Sealed sources

\section{Acceptable Waste Types:}

1. Soil and gravel

2. Concrete rubble

3. Scrap metal

4. Building rubble

5. PCB Bulk Product Waste meeting definition found in 40 CFR 761.62(b)(1).

6. Other materials may be acceptable (with prior approval on a case by case basis)

\section{Dose Rates and Radiological Concerns:}

1. Dose rates should be less than $5 \mathrm{mR} / \mathrm{hr}$ on contact of the loaded intermodal.

2. Dose rates shall be less than $5 \mathrm{mR} / \mathrm{hr} @ 30 \mathrm{~cm}$ from the waste.

3. Return survey requirements shall be clearly communicated to NNSS waste operations upon profile submission.

\section{Radionuclide Activities:}

1. Activities shall be less than 300 PE-g based on conversions in the NNSSWAC.

\section{Size, Weight, and Loading:}

1. All pieces within container shall be reduced to no larger than 3 feet in any dimension.

2. Soils need to be free of scrap metals, large rocks, or debris.

3. Maintain a clearance of at least 18 inches between the top of the waste and the bottom of the top header brace located near the door end of the container. 
4. Waste shall fit into the intermodal container without wedging into any area of the container.

5. The load shall be prepared to prevent movement during transportation and allow the waste to exit under the header and through the rear door with sufficient clearance to prevent jamming.

6. Precautions shall be taken during loading to ensure weight is not resting against the door.

\section{Weights:}

1. Weight of intermodal may not exceed $44,000 \mathrm{lb}$. gross weight.

2. Weight shall be evenly distributed.

\section{Liners:}

Waste shall be placed in a liner within the roll-off container:

1. Liners shall be at least 18 mil for scrap metals and debris

2. Liners shall be at least 12 mil for contaminated soils.

3. Liners shall be secured around the waste package and cannot be attached to the inside of the intermodal container.

4. Sufficient absorbent material needs to be added to prevent any accumulation of free liquids inside the container, either from precipitation penetration or from condensation.

\section{Marking and Labeling:}

1. All markings and labels not intended for NNSS or DOT use shall be obliterated.

2. All placards shall be removable by the transporter.

\section{Container Design:}

1. No top-hinged tailgate intermodals will be accepted for disposal.

2. There shall be no need for RWMC operations to open the top lid of the container for any reason.

3. There shall be attachments to secure the door in the open position during offloading.

4. Containers shall be at least standard $6^{\prime} \times 8^{\prime} \times 20^{\prime} \mathrm{ft}$ IP-1 intermodals.

\section{Off-Loading:}

Any container that does not off-load successfully will be buried intact. 
Appendix G

\section{Mixed Waste Forms}


This page intentionally left blank. 


\section{Appendix G - Mixed Waste Forms}

\section{G.1 Pre-Treatment Notification Form for Mixed Waste}

A. Generator Information

1. Company name:

2. Facility address:

3. Generator facility:

4. Primary technical contact:

5. Waste certification official:

email:

Phone:

Fax:

email:

Phone:

Fax:

B. General Waste Stream Information

1. Waste stream name:

2. Waste stream identification number:

3. Waste generating process description:

4. Estimated volume after treatment: Inventory attached

a. Estimated disposal container counts, container size, and weights:

b. Estimated container dose rates at 30 centimeters $(\mathrm{mR} / \mathrm{hr} @ 30 \mathrm{~cm})$ :

\begin{tabular}{|l|l|l|l|l|}
\hline Container Number & Container Count & Container Size & Weight $(\mathrm{lbs})$. & Dose rate $(\mathrm{mR} / \mathrm{hr}(\mathbf{a}) \mathbf{3 0} \mathrm{cm})$ \\
\hline $\begin{array}{l}\mathbf{5 5 - g a l l o n ~ C a r b o n} \\
\text { steel drums }\end{array}$ & $\mathbf{2 0 7}$ & $\mathbf{7 . 5} \mathbf{~ c u / f t}$ & $\sim \mathbf{6 0 0}$ & $<\mathbf{5 0}$ \\
\hline & & & & \\
\hline
\end{tabular}

5. Regulator status. Check all boxes below that describe the regulatory status of the waste stream as generated.

Federally regulated (RCRA) hazardous waste (40 CFR 261). List all EPA hazardous waste numbers and applicable regulatory subcategories:

State regulated hazardous waste codes:

6. Waste composition. Describe the gross composition/component of the waste stream and all hazardous constituents that contribute to any waste codes or LDR treatment standards.

\begin{tabular}{|c|c|c|}
\hline $\begin{array}{c}\text { CAS } \\
\text { Number }\end{array}$ & Chemical Constituent & Waste Component \\
\hline & & \\
\hline & & \\
\hline & & \\
\hline & & \\
\hline & & \\
\hline
\end{tabular}


7. Reportable radionuclides. List the radionuclides that could be reportable in the waste stream:

\begin{tabular}{|c|c|}
\hline Isotope & $\begin{array}{l}\text { Activity } \\
\left(\mathrm{Bq} / \mathrm{m}^{3}\right)\end{array}$ \\
\hline & \\
\hline & \\
\hline & \\
\hline
\end{tabular}

C. Proposed Treatment Information

1. Applicable LDR Treatment Standards:

2. Treatment standards: $\quad \square$ Concentration Based $\quad \square$ Technology Based

3. Proposed Treatment Facility:

$\square$ On-site Generator procedures:

$\square$ Commercial Facility name:

Address:

EPA Identification number:

Permit number:

4. DOECAP audit number and date completed of the treatment facility:

5. Treatment process(es) or technology(ies):

6. Proposed final waste form:

\begin{tabular}{lll}
$\square$ Solidified/Stabilized & $\square$ Debris & $\square$ Macroencapsulated \\
\hline Incinerator Ash & $\square$ Soil & $\square$ Other; describe:
\end{tabular}

7. $\square$ Waste will contain sorbent.

What kind? Sorbents used shall meet 40 CFR 264.314(e)(1) or (2).

8. Schedule for treatment:

9. Training or PPE necessary for visual inspection of treatment/waste:

Technical Contact Signature:

Date:

WCO Signature:

Date: 


\section{G.2 Mixed Waste Profile Annual Certification Example}

Waste Profile Number:

Waste Profile Revision No.:

Expiration Date:

Facility:

WCO:

The above Mixed Waste Profile (MWP) is about to expire. The NNSSWAC requires generators to recertify MWPs on an annual basis. No waste may be shipped under this profile after the expiration date unless it has been recertified or a new waste profile has been submitted and approved.

Please indicate your preference by checking the appropriate box below. If the waste stream has not changed significantly and the waste profile is still accurate, recertify by checking the third box below, providing the additional information requested, signing the certification statement, and returning this form to NNSA/NSO WMP. Upon approval, a letter will be sent which authorizes continued shipment of the waste stream for up to an additional year.

Check the appropriate box:

This waste profile is no longer needed. Please cancel the waste profile.

There have been significant changes to this waste stream. I understand that this waste stream cannot be shipped to the NNSS until a revised or new profile is approved. I will revise it or submit a new waste profile.

I want to recertify the waste profile. I have reviewed the revision no. and certify that it is current, complete, and accurate description of the waste stream and the methods employed to ensure that the waste meets the NNSSWAC.

If you checked the third box above, answer the following questions to confirm that the waste stream has not changed significantly. Significant changes will require a revision to the waste profile.

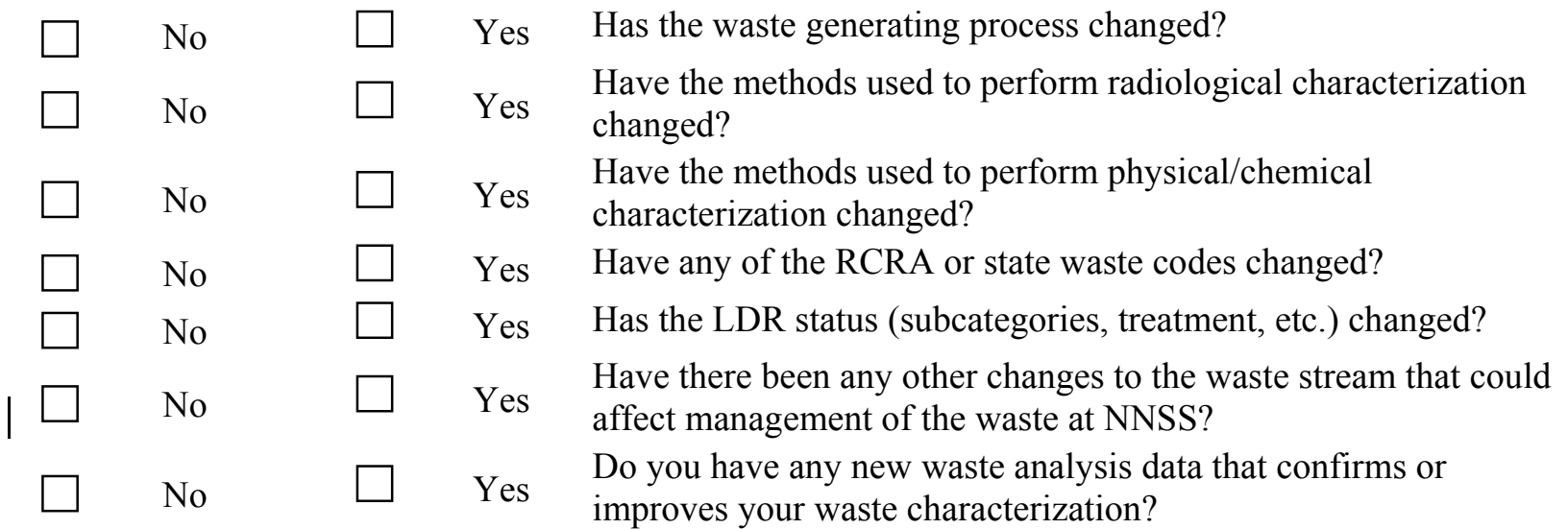

Provide the volume remaining in the waste stream:

If you checked any "Yes" boxes, please explain below and attach additional sheets as necessary. Certification: I certify that, to the best of my knowledge, the information provided on this form and any attached documentation is accurate and complete.

WCO Signature:

Date:

Print Name: 
This page intentionally left blank. 


\section{Appendix H}

\section{Glossary}


This page intentionally left blank. 


\section{Appendix H - Glossary}

Bulk Waste: Waste packaged in a soft-sided container (e.g. supersacks, burrito wraps), metal cage/pallet combinations or unpackaged waste items, SCO, LSA equipment, large machinery storage tanks, etc. See NNSSWAC Section 3.2.14 for additional information.

Certified Waste: Waste that has been confirmed to comply with disposal site Nevada National Security Site Waste Acceptance Criteria (NNSSWAC) under an approved certification program.

Chelating Agents: Amine polycarboxylic acids (e.g., EDTA, DPTA), hydroxy-carboxylic acids, and polycarboxylic acids (e.g., citric acid, carbolic acid, and gluconic acid).

Chemical Screening: Process in which waste is examined for characteristics such as ignitability, corrosivity, and reactivity.

Classified Waste: Radioactive waste for which access is limited for national security reasons and cannot be declassified will be managed in accordance with the requirements of DOE Directive 470.4 directives.

Closed Transport Vehicle: Transport vehicle or conveyance equipped with a securely attached exterior enclosure that during normal transportation restricts the access of unauthorized persons to the cargo space containing wastes transported for disposal at the NNSS. The enclosure may be either temporary or permanent, and in the case of packaged materials may be of the "see through" type, but must limit access from the top, sides, and bottom and provide protection from unfavorable weather conditions during transit.

Controlled Copy: An approved, uniquely numbered document regulated through controlled distribution.

Corrective Action: Measures taken to rectify conditions adverse to quality and, where necessary, to preclude repetition.

Declassification: A determination by an appropriate authority that information or matter no longer requires protection as classified information against unauthorized disclosure because of national security concerns.

Disposal: The emplacement of Low-Level Waste (LLW) or Mixed Waste (MW) in a manner, which is considered permanent in that routine recovery, is not provided for.

Facility Evaluation: A documented review to evaluate a generator's program for compliance with the NNSSWAC. Facility evaluations are conducted by Radioactive Waste Acceptance Program (RWAP) personnel in the form of an audit, surveillance, program reviews, or a combination of these.

Free Liquid: Liquids that readily separate from the solid portion of the waste including liquid that has been released during handling, storage, or transportation.

Friable Material: Any material containing more than one percent asbestos as determined using Polarized Light Microscopy, that, when dry, can be crumbled, pulverized, or reduced to powder by hand pressure.

Generator: An individual, facility, corporation, government agency, or other institution that offers waste 
for certification, treatment, or disposal.

Hazardous Waste Component: Waste identified or listed in Title 40 Code of Federal Regulations (CFR) 261, or that otherwise meets the Resource Conservation and Recovery Act (RCRA) definition of hazardous, or waste identified by applicable state-of-generation hazardous waste regulations.

Hydrocarbon Burdened LLW: Soil and closely related construction and demolition debris contaminated with greater than $100 \mathrm{mg} / \mathrm{kg}$ Total Petroleum Hydrocarbon (TPH) resulting from a petroleum release and generated by NNSA.NSO Operations.

Incompatible Waste: Waste type that might react adversely with its containment materials or commingled waste as defined in Title 40 CFR 260.10.

Inspection: A planned and documented activity, performed by authorized personnel, to verify that an item, service, or process conforms to specified criteria.

Item: An all-inclusive term used in place of any of the following: assembly, component, equipment, material, part, structure, or system. The term "item" may also include technical data, documents, computer codes, or samples.

Land Disposal Restricted (LDR) Waste: Waste that is prohibited from land disposal in accordance with Title 40 CFR 268.

Low-Level Waste: Low-level radioactive waste is radioactive waste that is not high-level radioactive waste, spent nuclear fuel, transuranic waste, by product material (as defined in section 11e.(2) of the Atomic Energy Act of 1954, as amended), or naturally occurring radioactive material. Small quantities of 11e.(2) byproduct material and naturally occurring radioactive material may be managed as low-level waste provided they can be managed to meet the requirements for low-level waste disposal (DOE M 435.1-1, Section IV.B.(4)). Test specimens of fissionable material irradiated for research and development only, and not for the production of power or plutonium, may be classified as LLW, provided the concentration of transuranic waste does not exceed $100 \mathrm{nCi} / \mathrm{g}$.

Mixed Waste: Waste containing both radioactive and hazardous components as defined by the Atomic Energy Act of 1954 (as amended) and the RCRA. MW shall meet the LDRs as listed in Title 40 CFR 268.

Nonconformance: A deficiency in characteristic, documentation, or procedure that renders the quality of an item or activity unacceptable or indeterminate.

Packaging: The assembly of components necessary to ensure compliance with U.S. Department of Transportation (DOT), U.S. Environmental Protection Agency (EPA), and NNSA/NSO requirements. It may consist of one or more receptacles, absorbent materials, radiation shielding, spacing structures, thermal insulation, and devices for cooling or absorbing mechanical shocks. The conveyance, tie-down system, and auxiliary equipment may sometimes be designated as part of the packaging.

Parcel: An individual component, item, or bag of waste, two or more of which may make up a package.

Pyrophoric Material: A material which, under normal conditions, is liable to cause fires through friction, retain heat from processing, or which can be ignited readily and, when ignited, burns so vigorously and persistently as to create serious transportation, handling, or disposal hazards. 
Qualification: The characteristics or abilities gained through education, training, or experience, as measured against established requirements, such as standards or tests that qualify an individual to perform a required function.

Qualified: Having complied with the specific requirements or precedent conditions.

Quality Assurance: All those planned and systematic actions necessary to provide adequate confidence that a structure, system, or component will perform satisfactorily in service.

Radioactive Waste: Solid, liquid, or gaseous material that contains radioactive nuclides regulated under the Atomic Energy Act of 1954 (as amended).

Radioactive Waste Management Site: Designated locations where radioactive waste handling and disposal operations are conducted.

Real-Time Radiography: X-ray unit used to examine waste packages.

Removable Contamination: Removable radioactive material on the package surface or shipping vehicle.

Stabilization: A technique that limits the solubility and mobility of waste constituents by bonding or chemical reaction with the stabilizing material.

Sealed Sources: Sources where the radioactive material is contained in a sealed capsule, sealed between layers of non-radioactive material, or firmly fixed to a non-radioactive surface by electroplating or other means. The confining barrier prevents dispersion of the radioactive material under normal and most accidental conditions related to the use of the source.

Solidification: A technique that limits the solubility and mobility of waste constituents by immobilization through physical means.

Supplier: Any individual or organization who furnishes items or services in accordance with a procurement document. An all-inclusive term used in place of any of the following: vendor, seller, contractor, subcontractor, fabricator, consultant, and their sub tier levels.

Tamper-Indicating Devices: Devices that may be used on containers and that, because of their uniqueness in design or structure, reveal violations of containment integrity.

Treatment: Any method, technique, or process designed to change the physical or chemical character of waste to render it less hazardous; safer to transport, store, or dispose; or reduced in volume. Five basic treatments are (a) volume reduction, (b) immobilization of radioactive/hazardous components, (c) change of composition, (d) removal of radioactive or hazardous components from the waste, and (e) solidification of liquids.

Uniform Hazardous Waste Manifest: The shipping document EPA Form 8700-22 originated and signed by the generator in accordance with the instructions included in the Appendix to Title $40 \mathrm{CFR}$ 262.

Verification Sampling: A NNSA/NSO program that confirms the accuracy and precision of a generator's analytical data by obtaining split samples of the waste from the generator, and having them analyzed. 
Waste Characterization: Determination of the physical, chemical, or radiological properties of waste.

Waste Package: Packaging / container (i.e., drum, metal box, soft-sided bags, cargos) that together with its contents of LLW or MLLW in final form for disposal / burial at the NNSS.

Waste Stream: A waste or group of wastes from a process or a facility with similar physical, chemical, and radiological properties. 
This page intentionally left blank. 



\section{References}

$\begin{array}{ll}\begin{array}{l}\text { Text } \\ \text { Superscripts }\end{array} & \begin{array}{l}\text { Requirement Docum } \\ \text { Code of Federal Regula } \\ \text { Title 10 - Energy }\end{array} \\ 1.1 & \text { 10 CFR 61.56(a)(5) } \\ 1.2 & \text { 10 CFR 61.56(a)(8) } \\ 1.3 & \text { 10 CFR 830.122 } \\ 1.4 & \text { 10 CFR 850.32(b) } \\ 1.5 & \text { 10 CFR 850.38 } \\ 1.6 & \text { 10 CFR 835, Appendix D }\end{array}$

\section{Title 29 - Labor}

2.129 CFR 1910.178(0)(2)

Title 40 - Protection of Environment

$\begin{array}{ll}3.1 & \text { 40 CFR 260.11(a) } \\ 3.2 & 40 \text { CFR 261 } \\ 3.3 & 40 \text { CFR 261.1(a) } \\ 3.4 & 40 \text { CFR 262.20(a) } \\ 3.5 & 40 \text { CFR 262.32(b) } \\ 3.6 & 40 \text { CFR 264.170 - .179 } \\ 3.7 & 40 \text { CFR 264.314(d) } \\ 3.8 & 40 \text { CFR 265.177 } \\ 3.9 & 40 \text { CFR 265.314 } \\ 3.10 & 40 \text { CFR 265.315 } \\ 3.11 & 40 \text { CFR 268 } \\ 3.12 & 40 \text { CFR 268.7 } \\ 3.13 & 40 \text { CFR 761.50(b)(7)(ii) } \\ 3.14 & 40 \text { CFR 761.60(b)(4) } \\ 3.15 & 40 \text { CFR 761.60(b)(6)(ii)(A) } \\ 3.16 & 40 \text { CFR 761.61(a)(5)(i)(B)(2)(ii) } \\ 3.17 & 40 \text { CFR 761.61(a)(5)(v)(A) } \\ 3.18 & 40 \text { CFR 761.62(b)(1)(i and ii) } \\ 3.19 & 40 \text { CFR 761.64(b)(2) } \\ 3.20 & 40 \text { CFR 761.79(g)(6) } \\ 3.21 & 40 \text { CFR 761.62(b)(4)(i) } \\ 3.22 & 40 \text { CFR 761.40 }\end{array}$




\section{Title 49 - Transportation}

$\begin{array}{ll}4.1 & \text { 49 CFR } 172.200-.205 \\ 4.2 & 49 \text { CFR } 172 \text { Subparts D and E } \\ 4.3 & \text { 49 CFR } 172.310 \\ 4.4 & \text { 49 CFR } 173.410 \\ 4.5 & 49 \text { CFR } 173.24 \\ 4.6 & 49 \text { CFR } 173.423 \\ 4.7 & 49 \text { CFR } 173.427 \\ 4.8 & \text { 49 CFR } 173.427(\mathrm{a})(6)(\mathrm{ii}) \\ 4.9 & \text { 49 CFR } 397.101 \\ 4.10 & \text { 49 CFR } 173.453 \\ 4.11 & \text { 49 CFR } 173.403\end{array}$

$\begin{array}{ll}5.1 & \text { NAC } 444.971(1) \\ 5.2 & \text { NAC } 444.971(2) \\ 5.3 & \text { NAC } 444.8565(2)(\text { b) } \\ 5.4 & \text { NAC } 444.8632\end{array}$

\section{Nevada Administrative Code (NAC)}

Department of Energy - Orders (O) \& Manuals (M)

DOE O 420.1, "Facility Safety"

$\begin{array}{ll}6.1 & 420.1 \\ 6.2 & 420.3 .2 \\ 6.3 & 4.3 .3\end{array}$

6.3 DOE M 470.4-4, "Information Security"

DOE M 470.4-6, "Nuclear Material Control and Accountability"

6.3.1 470.4-6, Section A, II-12 5(a)(2)

DOE $O$ 435.1, "Radioactive Waste Management"

DOE M 435.1-1 "Radioactive Waste Management"

$\begin{array}{ll}6.4 & 435.1-1 \\ 6.5 & 435.1-1 \text { III. A } \\ 6.6 & 435.1-1 \text { IV. G(1) } \\ 6.7 & 435.1-1 \text { IV. G(1)(a) } \\ 6.8 & 435.1-1 \text { IV. G(1)(b) } \\ 6.9 & 435.1-1 \text { IV. G(1)(c) } \\ 6.10 & 435.1-1 \text { IV. G(1)(d)(1) } \\ 6.11 & 435.1-1 \text { IV. G(1)(d)(2) } \\ 6.12 & 435.1-1 \text { IV. G(1)(d)(3) } \\ 6.13 & 435.1-1 \text { IV. G(1)(d)(4) }\end{array}$




$\begin{array}{ll}6.14 & 435.1-1 \text { IV. } G(1)(d)(5) \\ 6.15 & 435.1-1 \text { IV. G(2) } \\ 6.16 & 435.1-1 \text { IV. I } \\ 6.17 & 435.1-1 \text { IV. I(1) } \\ 6.18 & 435.1-1 \text { IV. I(2) } \\ 6.19 & 435.1-1 \text { IV. I(2)(b) } \\ 6.20 & 435.1-1 \text { IV. I(2)(d) } \\ 6.21 & 435.1-1 \text { IV. J(2) } \\ 6.22 & 435.1-1 \text { IV. K } \\ 6.23 & 435.1-1 \text { IV. O }\end{array}$

6.24 DOE O 414.1, “Quality Assurance”

\section{Federal Manuals, Policy, and Organizations}

7.1 DOE Hoisting \& Rigging Manual, DOE-STD-1090-Current Publication

7.2 State of Nevada Solid Waste Disposal Site Permit (SW1300001, current revision)

7.3 "Position Paper on the Proper Characterization and Disposal of Sealed Radioactive Sources." Revision 2, October 1997

7.4 Memo 9109-35 to Carol A. Shelton from Steve Okosisi, 11-21-1995, "Request for Evaluation of NVO-325 Criteria to Ensure Safe and Compliant Radioactive Waste Disposal Operations."

7.5 NNSA/NSO RWAP

N.6 NSA/NSO Operations

7.7 “Test Methods for Evaluating Solid Waste, Physical/Chemical Methods," EPA Publication SW-846, Chapter 1, Section 1.0, 12/1996

7.8 Low-Level Waste Licensing Branch, Technical Position on Radioactive Waste Classification, May 1983, Revision 0, Section C.1.c

7.9 NNSA/NSO Performance Assessment

7.10 USEPA "Waste Analysis at Facilities that Generate, Treat, Store, and Dispose of Hazardous Wastes" PB94-463603, OSWER 9938.4-03, April 1994, Section 1.5.2

7.11 Title 42 USC, Chapter 23, Section 2021.c(b)(2)

7.12 "Position on the Use of Lead Shielding for the Disposal of Low Level Radioactive Waste at the Nevada Test Site," current version.

7.13 DOE/NV letter from Carl P. Gertz, 8/19/1998, "Contamination Release Limits for Radioactive Waste Transport Vehicles."

7.14 T. P. McLaughlin, "Nuclear Criticality Safety Review of Low-Level Waste Disposal at the Nevada Test Site Radioactive Waste Management Sites," CSR-A490.100, August 2002. 
7.15 Bechtel Jacobs Company, "Nuclear Criticality Safety for Emplacement of ORR Waste at the Nevada Test Site, NCSE-MS-NTS1492, Rev. 0, August 2001.

7.16 S. G. Vessard and T. P. McLaughlin, "Nuclear Criticality Safety Evaluation of Low Level Waste Disposal at the Nevada Test Site Radioactive Waste Management Sites," Criticality Safety Evaluation (CSE)-A490.101, August, 2002.

7.17 S. G. Vessard and T. P. McLaughlin, "Nuclear Criticality Safety Evaluation of Low Level Waste Disposal at the Nevada Test Site Radioactive Waste Management Sites," CSE-A490.103, September, 2003.

7.18 Memo A490-06-TC-0005 to James B. Zovi from Thomas Collens, May 23, 2006, "Isotopes with No Direct Plutonium Equivalent Conversion Factor in the Nevada Test Site Waste Acceptance Criteria."

7.19 Radioactive Waste Projects - NSTec

\section{NTS Permits and Plans}

8.0 RWAP-P2, RWAP Waste Analysis Plan

8.1 RWAP Procedure, RWAP-09, Waste Verification Process 